\title{
BUKU AJAR ENTREPRENEURSHIP \& STARTUP ENTREPRENEUR YANG UNGGUL
}

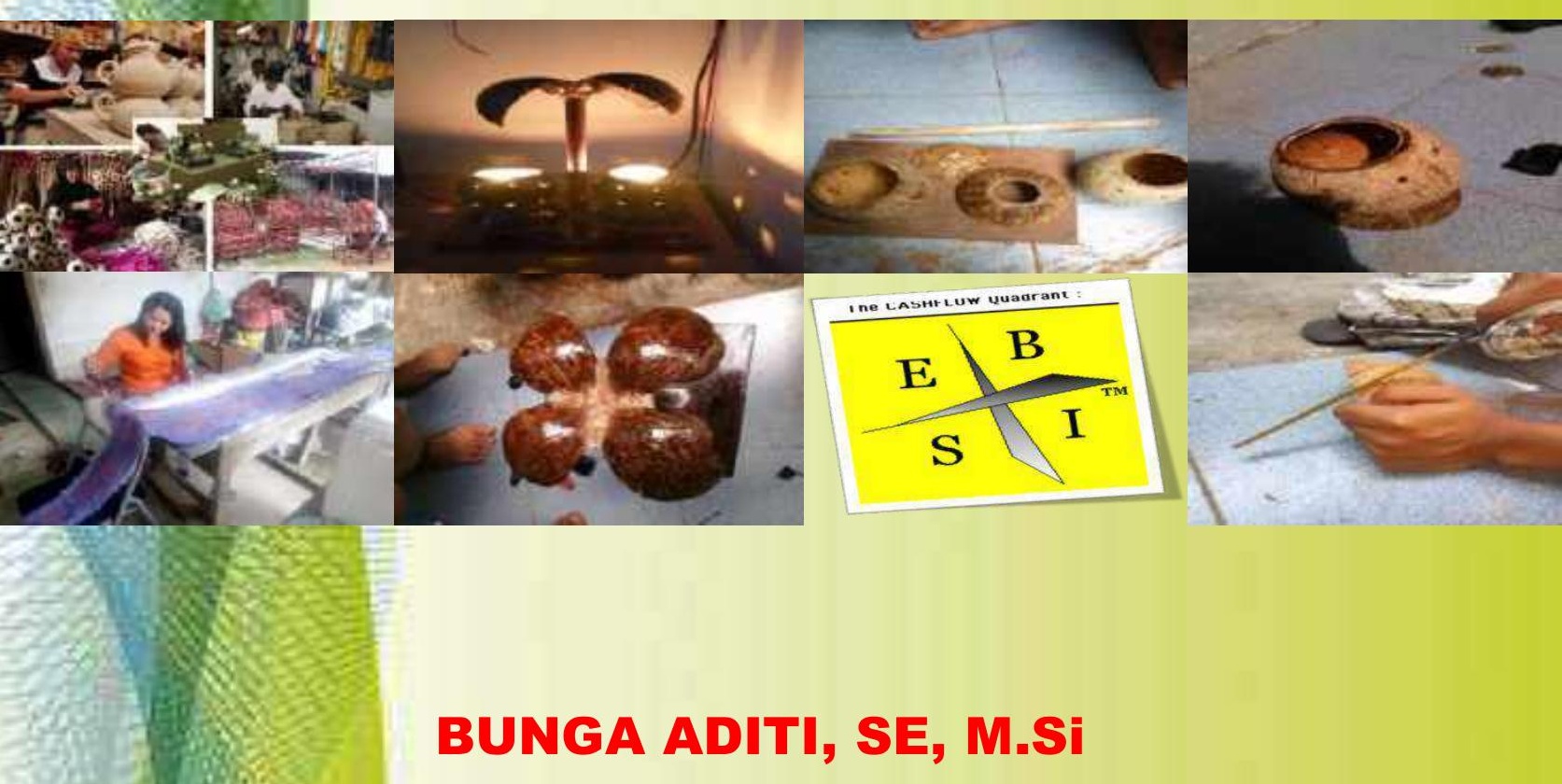




\section{Buku Ajar ENTREPRENEURSHIP \& STARTUP ENTREPRENEUR YANG UNGGUL}

\section{Bunga Aditi, S.E, M.Si}

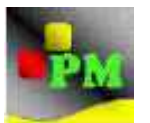

Penerbit Perdana Medika, 2018 
Copyright $\odot 2018$ by Perdana Medika

Perpustakaan Nasional RI : Katalog Dalam Terbitan (KDT)

\author{
BUKU AJAR ENTREPRENEURSHIP \& \\ STARTUP ENTREPRENEUR YANG UNGGUL
}

\title{
ISBN : 978-602-52932-8-3
}

Penulis : Bunga Aditi, S.E, M.Si

Editor : Muchti Yuda Pratama

Desain Sampul dan Tata Letak: Mahatir Muhammad

Penerbit : Perdana Medika

Redaksi : Gg. Melati No. 13-A Kab. Deli Serdang Propinsi Sumatera Utara

HP : +6281361694230

e-mail: cv.perdanamedika@ gmail.com

Cetakan pertama, Oktober 2018

Hak cipta dilindungi undang-undang

Dilarang memperbanyak karya tulis ini dalam bentuk dan dengan cara apapun tanpa ijin tertulis dari penerbit. 


\section{KATA PENGANTAR}

Puji dan Syukur kami panjatkan kepada Allah SWT, yang maha pengasih dan penyayang. Berkat rahmat dan karunia-Nya, kami, Penulis akhirnya dapat menyelesaikan penyusunan Bahan Ajar ini dengan baik. Disamping itu, keberhasilan penulisan Bahan Ajar ini tidak terlepas dari bantuan dan kerjasama yang baik dari berbagai pihak.

Buku ini disusun oleh Penulis yang merupakan salah satu Dosen di Universitas Harapan Medan di Fakultas Ekonomi Bisnis Program Studi S1-Manajemen.

Buku yang berjudul "BUKU AJAR ENTREPRENEURSHIP \& STARTUP ENTREPRENEUR YANG UNGGUL" memiliki tujuan untuk memberikan pemahaman dasar mengenai kewirausahaan di tingkat Diploma dan Sarjana. Materi yang dibahas di dalam buku ini terdiri atas $18 \mathrm{Bab}$ yang berisi tentang teori-teori kewirausahaan, dan pengelolaan bisnis, praktik kewirausahaan dari para wirausaha dalam dan luar negeri, serta berbagai tips praktis pengelolaan bisnis. Di setiap bab dari buku ini juga dilengkapi dengan rangkuman, pertanyaan diskusi dan tugas pada masing masing bab untuk memberikan pemahaman yang lebih mendalam mengenai materi yang akan dibahas 
Akhir kata, Penulis melalui buku ini berharap berkontribusi terhadap pengembangan kewirausahaan di Indonesia, khususnya perguruan tinggi yang sejalan dengan program pemerintah untuk meningkatkan dan mengembangkan jumlah wirausaha yang berkualits dan memberikan nilai tambah bagi perekonomian Indonesia.

Penulis menyadari bahwa buku ini memiliki banyak kekurangan yang perlu diperbaiki dan disempurnakan dimasa yang akan datang. Oleh karena itu, penulis berharap untuk dapat memperoleh masukan dari berbagai pihak sebagai sarana untuk penyempurnaan buku dimasa yang akan datang.

Medan, Oktober 2018

Penulis,

Bunga Aditi, S.E, M.Si 


\section{DAFTAR ISI}

KATA PENGANTAR …............................................... i

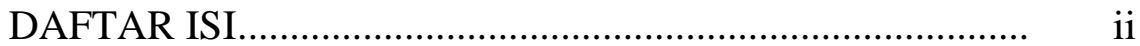

Bab I PENDAHULUAN

1.1. Latar Belakang Kewirausahaan ...................................... 1

1.2. Arti Kewirausahaan .................................................... 6

1.3. Karakter Wirausaha .................................................. 13

1.4 Jenis-Jenis Wirausaha ...................................................... 19

1.5 Menumbuhkan Keinginan Untuk Berwirausaha.............. 20

1.6 Kompetensi Kewirausahaan ......................................... 22

1.7. Faktor Penyebab Keberhasilan Dan Kegagalan Berwirausaha .............................................................. 23

Bab II INOVASI

2.1. Pengertian Inovasi.................................................... 26

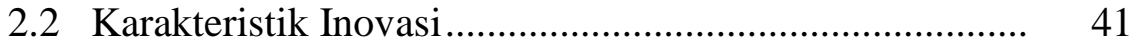

2.3 Jenis-Jenis Inovasi .......................................................... 42

2.4 Atribut Inovasi ........................................................ 45

2.5. Strategi dalam Inovasi .................................................... 49

Bab III BERPIKIR PERUBAHAN

3.1 Pentingnya Perubahan Dan Peranan Mindset (Pola Pikir) ................................................................... 51

3.2 Perubahan Mindset (Pola Pikir) ................................... 55

3.3 Pola Pikir Wirausaha ................................................... 58

3.4. Teori Kecerdaan Finansial ............................................... 59

Bab IV BERPIKIR KREATIF

4.1. Kreativitas sebagai modal penting wirauaha .................. 66

4.2. Hambatan Berpikir Kreatif ........................................... $\quad 72$

4.3. Mengukur Potensi Kreatif............................................ $\quad 75$

4.4. Teknik Untuk Meningkatkan Proses Kreativitas ............. 75

4.5. Hak Kekayaaan Intelektual (HKI) ................................. 81 
Bab V BERORIENTASI PADA TINDAKAN

5.1. Karakter yang berorientasi pada tindakan 83

5.2. Sikap Dan Tindakan Bagi Pribadi Yang Berorientasi pada tindakan 84

Bab VI PENGAMBILAN RESIKO

6.1. Konsep Resiko 89

6.2. Pengambilan Resiko 90

6.3. Mengidentifikasi Resiko Usaha 91

6.4. Pengelolaan Resiko 92

Bab VII KEPEMIMPINAN

7.1. Aspek Kepemimpinan Penting Bagi Wirausaha............. 94

7.2. Perbedaan Antara Manajer Dan Pemimpin 96

7.3. Kepemimpinan Awal Dan Kepemimpinan Kontemporer 98

Bab VIII ETIKA BISNIS

8.1. Peranan Etika Dalam Bisnis 100

8.2. Rahasia Sukses Jangka Panjang.... 102

Bab IX FAKOR X

9.1. Pengertian Faktor $X$ 104

9.2. Menggali Faktor $X$ 104

9.3. Sikap Menghadapi Faktor X 106

9.4. Tipe dan Karakteristik Faktor X 107

Bab X MENCARI GAGASAN UTAMA

10.1. Cara- Cara Mencari Gagasan Usaha 112

10.2. Kreatif, Konsultatif, Pelayanan dan Analitis 112

10.3. Usaha dari Imitasi 116

Bab XI PEMASARAN

11.1. Konsep Pemasaran 
11.2. Strategi Dan Taktik Pemasaran.................................. 121

11.3. Konsep Bauran Pemasaran ............................................ 133

Bab XII PERKEMBANGAN, PENGEMBANGAN KEWIRAUSAHAAN DAN UMKM

12.1 Perkembangan Kewirausahaan ................................... 140

12.2. Perkembagan Kewirausahaan ....................................... 141

12.3. Jenis-Jenis Usaha Kecil Berdasarkan Peluang yang Ada ................................................................... 143

12.4. Usaha Mikro Kecil dan Menengah .............................. 145

12.5. Faktor- Faktor Yang Mempengaruhi Kegagalan

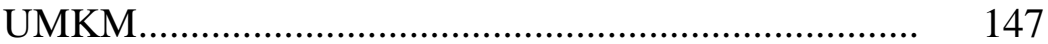

12.6. Faktor Pendukung Keberhasilan UMKM ..................... 147

12.7. UMKM Dan Pengembangan Melalui Pembinaan UMKM Oleh Pemerintah.......................................... 147

Bab XIII PRODUK

13.1 Pengertian Produk ...................................................... 152

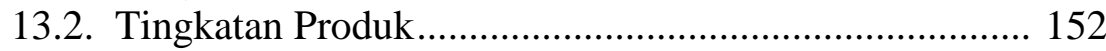

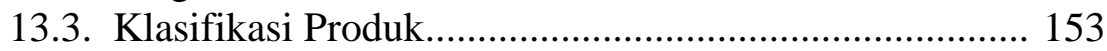

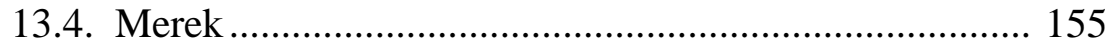

13.5. Daur Hidup Produk .................................................... 155

Bab XIV DESAIN KEMASAN

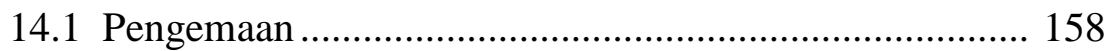

14.2. Fungsi Kemasan.

158

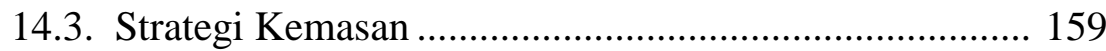

14.4. Jenis-Jenis Kemasan ................................................... 159

Bab XV BISNIS MODEL CANVAS

15.1. Pengertian Bisnis Canvas.............................................. 163

15.2. Cara Mengisi BMC .................................................... 164 
Bab XVI PERIZINAN USAHA

16.1 Surat Izin Usaha (SITU) ........................................... 176

16.2. Macam-macam Surat Izin Usaha ............................... 177

Bab VIII PROPOSAL BISNIS

17.1 Pengertian Proposal Bisnis ......................................... 185

17.2. Tujuan Proposa Bisnis ................................................ 185

17.3. Keuntungan Proposal Bisnis ........................................ 186

17.4. Komponen Proposal Yang Baik ................................... 186

DAFTAR PUSTAKA.................................... 206 


\section{BAB I \\ PENDAHULUAN}

Tujuan Pembelajaran:

Setelah mempelajari bab ini calon wirausaha diharapkan dapat mengerti

1. Latar Belakang Kewirausahaan

2. Dapat menjelaskan arti kewirausahaan

3. Dapat menjelaskan karakter seorang wirausaha

4. Menjelaskan Jenis-jenis wirausaha

5. Menumbuhkan keinginan untuk bewirausaha

6. Kompetensi Wirausaha

7. Faktor penyebab kegagalan dan keberhasilan wirausaha

\subsection{Latar Belakang Kewirausahaan}

Pada era Globalisasi ini, Entrepreneur menjadi suatu trend atau kebanggaan bagi orang yang baru atau sudah menjalankan usaha. Banyak orang yang terpacu untuk menjalankan bisnis baik kuliner, handycraft, industri rumah tangga, dll. Terjadi peningkatan UMKM dari tahun ketahun. Jumlah UMKM di tahun 2014 sebanyak 59,3 juta unit (99,9\% unit usaha). UMKM memberikan kontribusi yang begitu signifikan di dalam perekonomian nasional.

Pada tahun 1998 terjadinya krisis moneter, banyak perusahaan yang tidak sanggup untuk mejalankan atau 
mengembangkan binis bahkan perusahaan besar sekalipun mengalami kerugian atau penurunan laba. Daya beli konsumen menurun drastis karena itu terjadi pemutusan hubungan tenaga kerja. Daya beli konsumen menurun. Sedangkan untuk membeli bahan produksi berdasarkan harga dolar. Terjadi penaikan yang drastis untuk mata uang dolar, karena itu perusahaan juga harus menutupi semua biaya operasional tersebut, dengan cara menaikkan harga barang yang akan dipasarkan. Dan masyarakat juga mengalami kesulitan untuk membeli barang yang serba mahal, maka yang terjadi kurangnya minat beli konsumen dan berpikir untuk mengeluarkan dana kecuali hal-hal yang penting atau bersifat urgent.

Banyak Karyawan yang diberhentikan atau di PHK, tetapi UMKM yang masih berdiri kokoh. Karyawan yang pada awalnya di berada di zona yang nyaman, bekerja dan setiap bulan mendapatkan gaji, akhirnya harus mengalami bahwa mereka harus benar-benar siap untuk tidak lagi bekerja. Kekecewaan, kesedihan, keputusasaan pasti terjadi pada situasi tersebut.

Pada saat tersebut UMKM lah yang masih berdiri kokoh. Sebagai contoh usaha kuliner. Jika seseorang sudah merasa puas dan suka mengkonsumsi hasil atau produk dari kuliner, masyarakat tidak akan sungkan-sungkan mengeluarkan biaya untuk mendapatkannya walau dalam situasi yang sulit . 
UMKM (Usaha Mikro Kecil Menengah) menurut Undang-undang Nomor 20 tahun 2008 tentang UMKM

\begin{tabular}{|l|l|l|l|}
\hline \multicolumn{1}{|c|}{ Usaha } & \multicolumn{1}{|c|}{ Omset } & \multicolumn{1}{c|}{ Omset } & \multicolumn{1}{c|}{ Aset } \\
\hline Miko & $\begin{array}{l}\text { Sd } 300 \\
\text { Juta }\end{array}$ & 1 Juta/hari & Sd 50 juta \\
\hline Kecil & $\begin{array}{l}300 \text { juta }- \\
2.5 \text { milyar }\end{array}$ & 10 Juta/hari & $50-500$ juta \\
\hline Menengah & $\begin{array}{l}2.5 \text { milyar- } \\
50 \text { milyar }\end{array}$ & 200 juta/hari & $\begin{array}{l}500 \text { kita-10 } \\
\text { milyar }\end{array}$ \\
\hline
\end{tabular}

Populasi masyarakat Indonesia semakin lama semakin bertambah jumlahnya dari tahun ke tahun. Dan lulusan dari Akademi, Politeknik Negeri atau Swasa, Universitas, setiap tahunnya bertambah jumlah kelulusannya. Perusahaan tidak semua bisa menampung jumlah kelulusan tersebut. Oleh karena tersebut, pemerintah menggalakkan kewirausahaan di semua bidang pendidikan. Agar nantinya lulusan dari suatu kampus tidak hanya mengandalkan utuk bekerja di sutu perusahaan, tapi nantinya dapat bekerja secara mandiri, menjadi seorang entrepreneur dan akhir nya bisa membuka lapangan kerja dan memperkerjakan orang lain, tidak menjadi seorang pengangguran. Sebagaimana kita ketahui dampak pengangguran yang banyak, salah satu nya dapat menimbulkan suatu kejahatan atau perbuatan yang tidak positif. 
Tidak ada bangsa yang sejahtera dan dihargai bangsa lain tanpa kemajuan ekonomi. Kemajuan ekonomi akan dapat dicapai jika ada spirit kewirausahaan yang kuat dari warga bangsanya. China baik dijadikan contoh konkret dan paling dekat. Setelah menggelar pesta akbar olimpiade 2008 yang mencengangkan banyak orang beberapa waktu lalu, mereka kembali membuat dunia berdecak dengan kesuksesan astronotnya berjalan-jalan di luar angkasa. Dan kini dunia menantikan china turun tangan membantu mengatasi krisis keuangan global. Tanpa kemajuan ekonomi, tentu semua itu tak mungkin dilakukan China. Salah satu faktor kemajuan ekonomi China adalah semangat kewirausahaan masyarakatnya, yang didukung penuh pemerintahnya. China, Korea Selatan, dan India semakin berjaya mengibarkan produk-produknya sebagai bendera nasionalnya di pentas global.

Negara maju umumnya memiliki wirausaha yang lebih banyak ketimbang Negara berkembang, apalagi miskin. Amerika Serikat, misalnya. memiliki wirausaha 11,5 persen dari total penduduknya. Sekitar 7,2 persen warga Singapura adalah pengusaha sehingga negara kecil itu bisa maju.

Bangsa Indonesia semakin berpacu dengan bangsa lain yang sudah lebih dulu maju. Bahkan Negara - negara yang pernah mengalami krisis ekonomi seperti Indonesia, yang menyebabkan mulai bergantinya pelaku aktif di dunia bisnis, semakin jauh melesat. Koperasi baru terus bermunculan, 
dikendalikan kaum muda dengan visi bisnis yang kuat jiwa kewirausahaan yang tangguh. Pemimpin bisnis berusia muda terus bermunculan, siap membawa ekonominya melaju lebih pesat.

Banyak contoh pengusaha nasional antara lain Ciputra, Sofian Wanandi ,dan Arifin Panigoro. Bukan hanya mereka yang sudah senior dan telah mengenyam banyak asam garamnya bisnis, tetapi juga kalangan muda generasi kini, seperti Rachmat Gobel dan Anindya Bakrie. Mereka juga gemas karena melihat lambatnya kebangkitan wirausaha di kalangan kaum muda sendiri.

Sampai saat ini belum ada negara sekaya dan selengkap sumber daya alam Indonesia. Sejak zaman penjajahan, nusantara ini sudah menjadi sumber utama dunia akan hasil bumi dan laut, komoditas primer. Komoditas pertanian, perkebunan, laut, dan pantai Indonesia sudah jadi pembicaraan pebisnis global. Berdatangannya partikelir untuk berdagang, dan sebagian berujung penjajahan, adalah bukti otentik dari catatan sejarah masa silam itu.

Indonesia penghasil kakao terbesar ketiga di dunia, tapi bukan penghasil cokelat terkemuka. Swiss yang tidak punya lahan untuk menanam kakao menjadi produsen cokelat terkemuka. Swiss yang tidak punya lahan untuk menanam kakao menjadi produsen cokelat terkemuka. Bangsa Jepang tak punya sumber daya alam yang berlebihan tapi Negara ini bagaikan pabrik raksasa yang memasok kebutuhan hidup 
manusia sedunia. Semua itu karena kewirausahaan masyarakatnya yang kuat.

Oleh karena itu, untuk mempercepat pertumbuhan wirausaha di dalam negeri, harus ada upaya serius untuk menciptakan orang - orang yang mampu mengambil peluang yang ada dan menciptakan lapangan kerja untuk dirinya maupun untuk orang lain. Lembaga pendidikan mesti bisa berperan lebih banyak lagi untuk menumbuhkan semangat kewirausahaan dan membentuk orang - orang yang tahan banting dengan segala kesukaran yang dihadapi untuk membangun kemandirian.

Menyimak persoalan - persoalan seperti dikemukakan tersebut, maka dalam bab ini kita akan membahas tentang kewirausahaan dari segi pemahaman yang paling dasar.

\subsection{Arti Kewirausahaan}

Wirausaha berasal dari kata Wira yang artinya Pahlawan (berani) dan usaha berarti melakukan kegiatan usaha (bisnis). Badan Pusat statistik mendefiisikan unit usaha adalah unit yang melakukan kegiatan yang dilakukan oleh perseorangan atau rumah tangga maupun suatu badan dan mempuyai kewenangan yang ditentukan berasarkan kebenaran lokasi bangunan fisik, dan wilayah operasinya. Wirausaha merupakan orang yang mampu mengkombinasikn berbagai faktor produksi untuk menciptakan sesuatu yang baru dan 
memiliki nilai tambah melalui sebuah proses yang disebut kewirausahaan.

Kewirausahaan (entrepreneurship) adalah perkembangan selama bertahun- tahun dilakukan demi mewuudkan hasil karya tersebut. Istilah kewirausahaan awalnya dikenalkan di awal abad ke-18 oleh ekonom Perancis, Richard Cantillon, yang berpendapat bahwa entrepreneurship merupakan "agent who buys means of production at certain prices in order to combine them".

Secara etimologik, perkataan kewirausahaan (entrepreneur) berasal dari kata entrependre (bahasa inggris) yang berarti melakukan. Dengan demikian, kewirausahaan bukanlah bakat dari lahir atau milik etnis/suku tertentu. Kewirausahaan bukanlah mitos, melainkan realistik atau construct yang dapat dipelajari melalui proses pembelajaran, pelatihan, simulasi, dan magang secara intent.

Selain itu, definisi Kewirausahaan menurut Intruksi Presiden Republik Indonesia (INPRES) No. 4 Tahun 1995 tentang Gerakan Nasional Memasyarakatkan dan Membudayakan Kewirausahaan adalah semangat, sikap, prilaku dan kemampuan seseorang dalam menangani usaha dan/atau kegiatan yang mengarah pada upaya mencari menciptakan, menerapkan cara kerja, teknologi dan produk baru dengan meningkatkan efisiensi dalam rangka memberikan pelayan yang lebih dan/atau memperoleh keuntungan yang lebih besar. 
Kewirausahaan merupakan suatu ilmu yang mengkaji tentang pengembangan dan pembangunan semangat kreativitas serta berani menanggung resiko terhadap pekerjaan yang dilakukan demi mewujudkan hasil karya tersebut.

Seseorang wirausahawan selalu diharuskan menghadapi resiko atau peluang yang muncul, serta sering dikaitkan dengan tindakan yang kreatif dan innovatif. Selain itu, seorang wirausahawan menjalankan peranan manajerial dalam kegiatannya, tetapi manajemen rutin pada operasi yang sedang berjalan tidak di golongkan sebagai kewirausahawan. Seorang individu mungkin menunjukkan fungsi kewirausahaan ketika membentuk sebuah organisasi, tetapi selanjutnya menjalankan fungsi manajerial tanpa menjalankan fungsi kewirausahaannya. Jadi kewirausahaan bisa bersifat kondisional.

Karakteristik yang dimiliki oleh seorang wirausaha memenuhi syarat-syarat keunggulan bersaing bagi suatu perusahaan/organisasi, seperti inovatif, kreatif, adaptif, dinamik, kemampuan integrasi, daya - juang, dan kode etik niscaya mewujudkan efektivitas perusahaan/organisasi.

Berikut ini di presentasikan profil seorang wirausaha.

Tabel 1.1 Profil Seorang Wirausahaan

\begin{tabular}{|c|c|}
\hline $\begin{array}{c}\text { Karateristik } \\
\text { Profil }\end{array}$ & Ciri Wirausahaan yang Menonjol \\
\hline Berprestasi tinggi & Ahli untuk memperoleh prestasi. \\
\hline
\end{tabular}




\begin{tabular}{|l|l|}
\hline Pengambil risiko & $\begin{array}{l}\text { Mereka tidak takut mengambil risiko } \\
\text { tetapi akan menghindari risiko tinggi } \\
\text { apabila dimungkinkan. }\end{array}$ \\
\hline Pemecah masalah & $\begin{array}{l}\text { Mereka tanggap mengenali dan } \\
\text { memecahkan masalah yang dapat } \\
\text { menghalangi kemampuannya mencapi } \\
\text { tujuan. }\end{array}$ \\
\hline Pencari status & $\begin{array}{l}\text { Mereka tidak memperkenankan } \\
\text { kebutuhan terhadap status menggangu } \\
\text { nilai usahanya. }\end{array}$ \\
\hline Tingkatan energy & $\begin{array}{l}\text { Dedikasi dan } \text { workoholic demi } \\
\text { wujudnya sukses. }\end{array}$ \\
\hline Percaya diri & Tingkat confidence yang tinggi. \\
\hline Ikatan emosi & $\begin{array}{l}\text { Memisahkan antara hubungan } \\
\text { emosional dengan karier. }\end{array}$ \\
\hline Kepuasan pribadi & $\begin{array}{l}\text { Menyukai kompleksitas tinggi dengan } \\
\text { formalisasi yang rendah. }\end{array}$ \\
\hline
\end{tabular}

Sumber : David E. Rye: 1996

Dengan demikian, seorang wirausahawan mengetahui barbagai fungsi yang terkait dalam mengelola suatu perusahaan/organisasi, seperti fungsi manajemen, keuangan, pemasaran, produksi, operasi, sumberdaya manusia, organisasi dan kelembagaan. Wirausaha adalah seorang yang berorientasi prestasi dan meyakini bahwa mereka menguasai kemampuan sendiri. 
Beberapa contoh wirausaha dapat dilihat dari gambar sebagai berikut

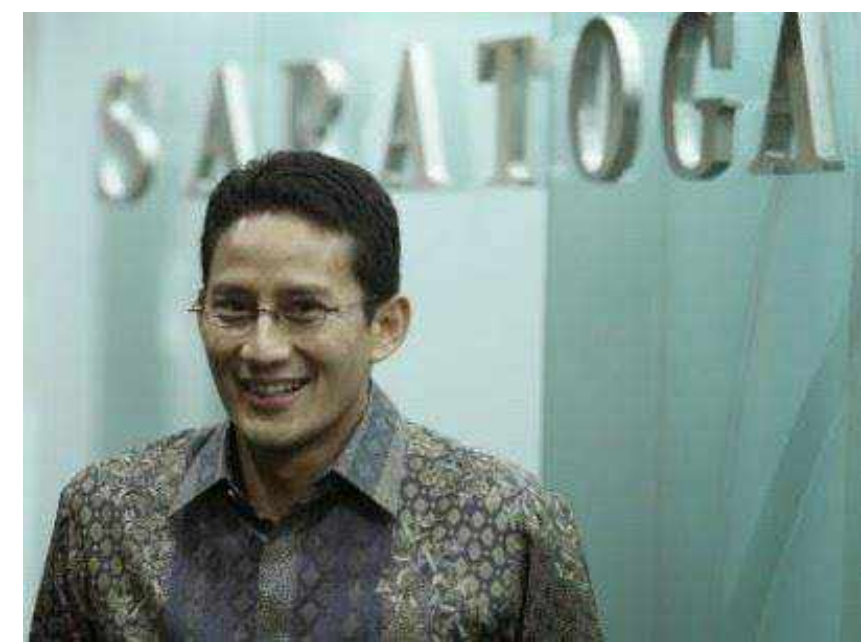

Salahudin Sandiaga Uno: Pengusaha di Indonesia

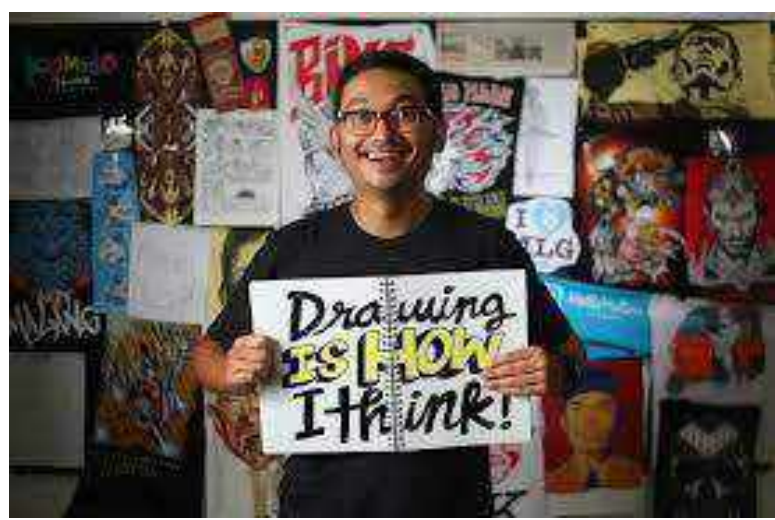

Wahyu Aditya Menjadi Pengusaha Muda dari Hobi Menggambar

Sumber: Biografi orang-sukses-dunia.blogspot.com 


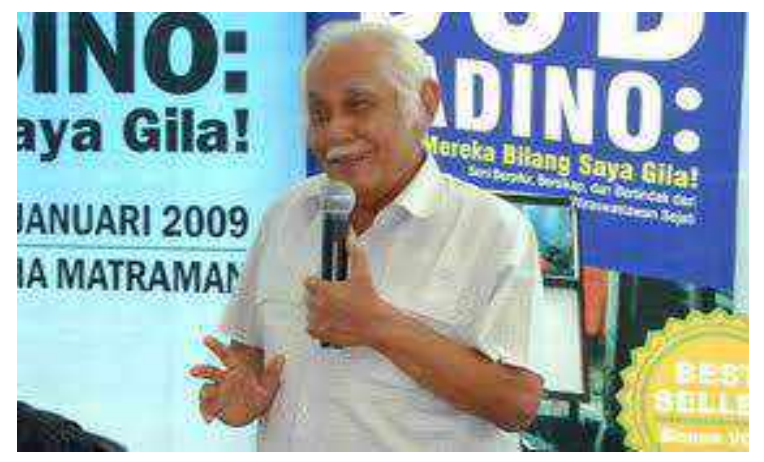

\section{Bob Sadiono: Pengusaha yang sukses dibidang Kuliner}

Siapa bilang hobi menggambar hanya bisa menjadi pelukis saja, siapa bilang hobi menggambar tak bisa membuat perusahaan, siapa bilang pelajaran menggambar tidak penting dan pelajaran matematika saja yang penting, siapa bilang kesuksesan hidup hanya milik si jenius matematika. Wahyu Aditya sangat tidak suka matematika bahkan dia bersumpah hanya mau kuliah di jurusan yang tidak ada matematikanya. Ia lebih suka bercoret-coret di kertas, menggambar berbagai tokoh imajinasinya daripada berlatih soal matematika. Namun toh keberhasilan hidupnya melalui hobi menggambar bisa melampaui sang ahli matematika. Bahkan Wahyu Aditya telah bisa mendirikan perusahaan sendiri dan mencetak pundi-pundi kekayaannya sendiri sewaktu umumnya masih berkepala dua dari hobinya menggambar. Inilah biografi Wahyu Aditya. Muda, pintar, kreatif, memiliki bisnis sendiri dan banyak uang, tentu menjadi impian banyak orang. Gara-gara sering 
menyaksikan acara "Gemar Menggambar" yang ditayangkan di TVRI era tahun 90-an, diusianya yang masih relatif muda, Wahyu Aditya yang lahir pada tanggal 4 Maret 1980 di Malang, telah memiliki semua impian hidup itu.

Dengan kemampuannya di bidang desain grafis dan animasi, ia menjadi pemain utama dalam bisnis animasi dan desain grafis di tanah air. Bahkan iapun banyak diburu oleh perusahaan kreatif untuk menggarap sederet pesanan iklan. Baik iklan komersial maupun iklan layanan masyarakat. Titik balik yang membuat nama Adit menggebrak dunia animasi Internasional adalah ketika dewan juri yang terdiri dari para pakar film Inggris menyatakannya sebagai juara International Young Screen Entrepreneur of the Year 2007. Pada event yang diselenggarakan oleh British Council di Apollo Theatre West End London. Wahyu Aditya telah berhasil menumbangkan saingannya yang berasal dari India, Cina, Brazil, Polandia, Slovenia, Lithuania, Nigeria, dan Lebanon.

Dewan juri menilai Adit berhasil memadukan antara kreativitas, idealisme dan bisnis di usianya yang masih sangat muda. Pada saat itu usianya baru 27 tahun namun ia telah berhasil mendirikan sekolah film Hello Motion dan memprakarsai festival film Hellofest dimana setiap tahun meraup 10 ribuan penonton muda di seluruh Indonesia. Di tengah keterbatasan industri animasi kreatif di tanah air, Aidit dinilai mampu menciptakan pasarnya sendiri. Sudah beberapa brand komersial ditanganinya antara lain PLN, Bushway, 
Kampanye pemilu, Jakarta Internasional Film Festival (JIFFEST) dan Pertamina. Siapakah sosok Wahyu Aditya atay akrab disapa Adit? Bagaimana tiba-tiba dari seseorang yang tak pernah terdengar namanya menjadi animator kelas dunia? Berikut ini Kisah Sukses dan Biografi Wahyu Aditya.

\subsection{Karakter Wirausaha}

Ada karakter-karakter yang paling dibutuhkan untuk mendukung munculnya seorang wirausaha yang berpeluang sukses tersebut, yaitu :

(1) Daya gerak (drive), seperti inisiatif, semangat, tanggungjawab, ketekunan dan kesehatan.

(2) Kemampuan berpikir (thingking ability), seperti gagasan asli, kreatif, kritis dan analitis.

(3) Kemampuan membina relasi (competency in human relation), seperti mudah bergaul (sociability), mempunyai tingkat emosi yang stabil (EQ tinggi), ramah, suka membantu (cheer fullness), kerja sama, penuh pertimbangan (consideration), dan bijaksana (tactfulness).

(4) Mampu menyampaikan gagasannya (communication skills), seperti terbuka dan dapat menyampaikan pesan secara lisan (bicara) atau tulisan (memo).

(5) Keahlian khusus (technical knowledge), seperti menguasai proses produksi atau pelayanan yang di bidangnya, dan tahu dari mana mendapatkan informasi yang diperlukan.

(6) Bukan sekedar tumpangan hidup 
Sekalipun UMKM menjadi tumpuan hidup yang penting , tapi tidak semua orang yang memiliki usaha adalah seorang wirausaha. Wirausaha adalah seorang yang penuh dengan keberanian dan kegigihan sehingga usahanya mengalami pertumbuhan . Jadi, bertumbuh menjadi kata kunci dalam berwirausaha. Dengan demikian orang-orang yang memilih tidak bekerja pada sebuah perusahaan dan memiliki usaha sendiri, mereka belum layak disebut sebagai wirausaha. Contoh, jika mereka hanya sekedar membuka usaha seperti warung kecil,sekedarnya saja,untuk menambah penghasilan, maka mereka hanyalah pedagang biasa. Mereka hanya usaha stagnan, tak ada perubahan dari waktu ke waktu, dari warung kecil jadi sebuah toko grosir dan akhirnya besar menjadi supermarket, dari yang memiliki sedikit karyawan hingga memiliki ratusan karyawan. Tak peduli apakah dia pekerja seni, wartawan atau pekerja sosial siapa saja yang melakukan hal tersebut, dia layak disebut sebagai wirausaha.Wirausaha bukan hanya sekedar untuk menumpang hidup, tapi membuat hidup lebih menarik dan berkelanjutan.

(6) Bersahabat dengan ketidakpastian

(7) Percaya diri (self Confidence)

Seseorang harus percaya pada diri sendiri artinya yakin akan melakukan suatu usaha tertentu dengan bekal pengetahuan, keterampilalan dan pengalaman yang dimiliki. Sebagai contoh seseorang yang pernah bekerja 
sebagai karyawati sebuah restoran selama 5 tahun pastilah memiliki pengalaman dan pengetahuan untuk mengelola restoran. Dengan bekal pegalaman tersebut akan timbulllah keyakinan dan rasa peraya diri untuk mengelola isnis restoran juga, jika peluang ada padanya.

(8) Berani mengambil resiko.

Seorang wirausaha harus berani menghadapi resiko kegagalan yang dapat saja terjadi. Kegagalan merupakan keberhasilan yang tertunda. Resiko kegagalan merupakan suatu fakta yang harus di telusuri apa penyebabnya. Namun kegagalan bukanlah akhir dari suatu usaha yang dilakukan.

Ada berbagai macam resiko dalam mengelola bisnis, diantaranya adalah:

1. Resiko yang terjadi karena tidak sengaja diperbuat, seperti bencana alam, seperti banjir, gempa bumi, kebakaran, kehilangan, angin topan dan lain-lain

2. Resiko yang terjadi karena kegagalan dalam operasional kerja, seperti gagalnya mimilih bahan baku, bahan penolong, gagalnya memilih karyawan yang tepat, gagal dalam proses produksi, gagal dalam pemasaran dan penjualan, gagal mengawasi keuangan usaha dan sebagainya.

(9). Segera mengambil tindakan untuk memulai usaha setelah melihat peluang bisnis (Action Oriented)

Sebelum melakukan usaha kebanyakan orang hanya berpikir terus, berkata-berkata terus akan 
menjalankan usaha tetapi tidak mengambil tindakan memulai usaha. Ada yang berpikir harus memiliki banyak modal, atau perizinan terlebih dahulu, tetapi tidak juga dimulai usahanya. Menurut Rhenald Kasali (2010) wirausaha harus berorientasi pada PDCA (plan, do, check, action), dan menghindari NATO (no action talk only, NADO (no action dream only, dan NACO (no action concept only)

(10)Selalu berpikir dan berusaha mencari peluang usaha baru

Wirausaha yang sukses adalah wirausaha yang dapat cepat melihat peluang bisnis dan segera memulai usaha.

Karakter wirausaha yang utama adalah memiliki persahabatan yang cukup kental dengan ketidakpastian. Berbeda dengan pekerjaan menjadi pegawai,wirausaha akan menjalani hari-harinya dengan hal yang tidak pasti. Faktanya adalah banyak sarjana memilih bekerja menjadi pegawai negri atau karyawan di sebuah perusahaan, dengan harapan nantinya menjadi seorang manajer. Penghasilan yang kecil tidak masalah, yang penting selalu menerima gaji setiap bulannya. Setiap bulan nya. Setiap bulan pada setiap tanggal yang sama menerima jumlah penghasilan yang tetap, setiap tahun ada kenaikan jabatan, mutasi, mendapatkan posisi yang lebih baik, anak dan istri mendapat tunjangan, semua itu pasti didapat 
ketika menjadi karyawan atau pegawai. Menjadi wirausaha pastinya berbeda ,tidak akan ada penghasilan tetap, semua fasilitas harus dibayar sesuai dengan uang yang diperoleh, bahkan ketika baru memulai usaha, kesulitan keuangan pastinya terjadi, keahlihan yang cukup, bahkan kepercayaan dari konsumen belum stabil, semua melalui proses yang penuh dengan tantangan. Ketidakpastian menjadi langkah yang menantang bagi seorang wirausaha. Karena banyak orang yang tak mampu melaluinya, banyak orang tersesat dan alik arah kembali menjadi pegawai , padahal bagaimana pun juga dunia selalu berubah dan dunia penuh dengan ketidakpastian. .

Tabel 2

Perbedaan antara usaha yang rill dan usaha yang spekulatif

\begin{tabular}{|l|l|}
\hline \multicolumn{1}{|c|}{ Usaha Rill } & \multicolumn{1}{|c|}{ Usaha spekulatif } \\
\hline Wealth = Well being & Wealth=Money \\
\hline $\begin{array}{l}\text { Wealth=wealth (kehidupan yang } \\
\text { llectual) }\end{array}$ & $\begin{array}{l}\text { Illusiaonary } \\
\text { wealt,magic.(kehidupan } \\
\text { yang biasa didapat melalui } \\
\text { spekulasi). }\end{array}$ \\
\hline $\begin{array}{l}\text { Saling } \\
\text { memelihara/menjaga.(menguran } \\
\text { gi ketergantingan pada } \\
\text { uang.Mengutamakan tata nilai). }\end{array}$ & $\begin{array}{l}\text { Aset yang terus meningkat } \\
\text { nilainya,penampilan yang } \\
\text { berlebih,(over valued asset } \\
\text { handsome performance). }\end{array}$ \\
\hline $\begin{array}{l}\text { Kekayaan yang diperoleh dari } \\
\text { kerja keras,inovasi, persaingan }\end{array}$ & $\begin{array}{l}\text { Yang kaya semakin kaya, } \\
\text { uang bisa memperbesar } \\
\text { uang. }\end{array}$ \\
\hline
\end{tabular}




\begin{tabular}{|c|c|}
\hline $\begin{array}{l}\text { "Jangan berilusi, bekerja } \\
\text { keraslah, hidup yang hemat, } \\
\text { nikmati pada masanya." Bekerja } \\
\text { sekarang, nikmati hari tua, dan } \\
\text { sisakan untuk generasi yang } \\
\text { akan datang. }\end{array}$ & $\begin{array}{l}\text { "Jangan bekerja untuk } \\
\text { uang,buatlah uang bekerja } \\
\text { untuk anda". Bekerja hari } \\
\text { ini untuk hari ini. }\end{array}$ \\
\hline $\begin{array}{l}\text { Kontribusi ekonomi dalam } \\
\text { jangka panjang terhadap } \\
\text { manusia dan alam/habitatnya. }\end{array}$ & $\begin{array}{l}\text { Tingkat pengembalian } \\
\text { (Rate of Return) kinerja } \\
\text { ekonomi(economic } \\
\text { permormance), } \\
\text { peringkat(Rating and } \\
\text { scoring). }\end{array}$ \\
\hline Tradisi Marker Strett & Tradisi wall street \\
\hline
\end{tabular}

Tidak ada cara yang pintas, atau cara cepat jadi kaya.Kaya bukan menjadi orientasi utama seorang wirausaha. Kaya adalah akibat, yaitu akibat dari perilaku berusah yang jujur,hasil dari bekerja keras dan kepercayaan.

Menuntut waktu dan bersungguh-sungguh. Tujuan berwirausaha adalah hidup bahagia dan mandiri. Sementara usaha-usaha yang spekulatif adalah usaha yang hanya ditujukan untuk mengejar kekayaan dalam waktu singkat,tanpa kerja keras. Tujuan mereka adalah kaya.Yang pada akhirnya bukan menimbulkan kesejahteraan atau tidak bahagia. Usaha spekulatif bukan usaha seorang wirausaha, sebab usaha spekulatif tidak membutuhkan proses pertumbuhan. Bagi 
mereka yang paling penting adalah kaya dalam waktu yang singkat.

Sedangkan menurut Mcgraith dan Mac Milan (2000), sebagai berikut:

1. Action oriented

2. Berpikir simple

3. Mereka selalu mencari peluang baru

4. Mengejar peluang dengan disiplin tinggi

5. Hanya mengambil peluang terbaik

6. Fokus pada eksekusi

7. Memfokuskan energy setiap orang pada bisnis.

\subsection{Jenis-jenis Wirausaha}

Akhirnya setiap orang yang mengambil peran atau karier sebagai wirausaha perlu mengetahui pilihan-pilihan apa saja yang tersedia dengan menjadi intrapeneur, entrepreneur atau social entrepreneur maupun technopreneur. Penjelasannya sebagai berikut:

1. Entrepreneur :adalah orang yang mampu mengolah sumber daya yang ada menjadi suatu produk yang mempunyai nilai atau mencari keuntungan dari peluang yang belum digarap orang lain 


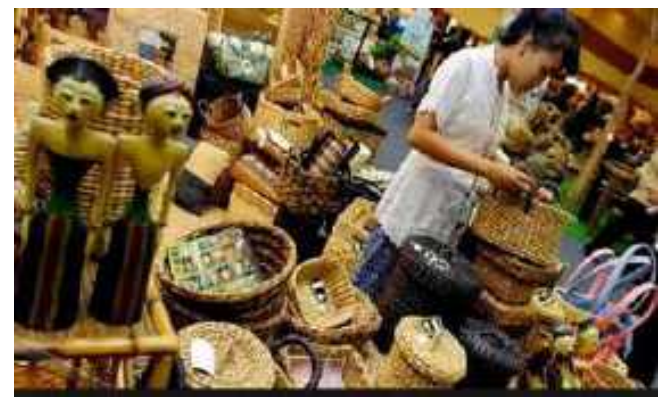

2. Intrapreneurship: Mereka yang menciptakan ide baru dan mengembangkannya menjadi proyek yang sukses didalam tempat mereka bekerja

3. Technopreneur adalah integrasi antara teknologi dan entrepreneurship skill.

Contohnya adalah wirausahawan yang membuat spinner ( Alat Pengering minyak)

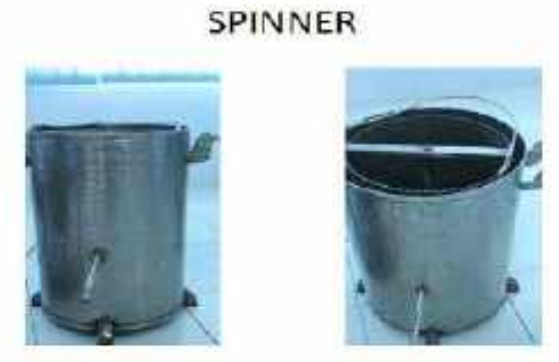

\subsection{Menumbuhkan keinginan untuk berwirausaha.}

Ada berbagai macam cara yang dapat dilakukan seseorang untuk menumbuhkan jiwa kewirausahaan antara lain:

1. Pengamatan (observasi) terhadap lingkungan sekitar Contoh: melihat berbagai macam usaha seperti bidang pertanian kerjinan, usaha jasa, travel, peternakan, perikanan. 
Dengan cara tersebut dapat menemukan ide usaha untuk memotivasi diri.

2. Dengan melakukan kunjungan ke unit-unit usaha kecil (UKM). Dengan cara ini memungkinkan kita memperoleh gambaran tentang usaha yang sedang dikelola oleh wirausaha, mulai dari sejarah berdirinya, kiat sukses wirausaha ataupun hambatan yang pernah dan sedang dialaminya.

3. Modal utama wirausaha ada keyakinan untuk menang bukan uang. Adanya keyakinan untuk menang dari kegagalan jadi bukan semata-mata hanya mendapatkan uang tapi usaha dan kerja keras membuat kemenangan dalam menjalankan bisnis.

4. Konsentrasi pikiran anda pada perubahan pola pikir.

Pola pikir (mindset) harus diubah dari pola pikir konsumtif menjadi produktif. Sebagai contoh seseorang mempunya rumah dengan pekarangan yang luas. Pekarangan tersebut dapat dimanfaatkan untuk membuka usaha ataukah disewakan seperti membuka usaha baik cafe, butik, dll.

5. Bersahabat dengan yang tidak pasti.

Artinya dalam berwirausaha memang ada resikonya. Tetapi kita harus bersahabat dengan ketidakpastian. Anggap sesuatu yang postif dan belajar dari pengalaman.

6. Buka pikiran dan pelajari hal-hal baru. 
Selau berkreatifitas dan berinovasi menemukan hal-hal yang baru, agar produk yang dipasarkan selalu upto date dan sesuai dengan keinginan pasar yan dibutuhkan.

7. Be ready, persiapkan diri anda dengan baik

Persiapkan diri baik dari segi manajemen maupun finansial

8. Tampilkan wajah yang enak dilihat,bangun network

Selalu bersikap ramah, banyak tersenyum dan membangun serta memperluas jaringan demi mendapatkan pasar.

9. Kurangi resiko dengan dukungan data, informasi-informasi juga kemampuan-kemampuan teknis.

Data yang lengkap, biodata customer dan informasi serta kemampuan membuat usaha lebih berkembang.

\subsection{Kompetensi Wirausaha}

Salah satu penyebab kegagalan berwirausaha adalah kurangnya memiliki kompetensi sesuai dengan usaha yang dikelolanya. Kompetensi (pengetahuan dan keterampilan) yang harus dimiliki wirausaha antara lain:

1. Pengetahuan bidang usaha dan bentuk usaha yang akan dimasuki.

2. Pengetahuan dan keterampilan dalam mengelola usaha yang mencakup produksi, pemasaran, keuangan, dan sumber daya manusia.

3. Pengetahuan tentang lingkungan usaha yang dapat mempengaruhi aktivitas usaha yang meliputi baik lingkungan umum maupun lingkungan khusus. 
4. Pengetahuan dan keterampilan dalam memecahkan permasalahan yang terjadi dan pengambilan keputusan.

5. Keterampilan berkomunikasi dan menciptakan jaringan kerjasama.

\subsection{Faktor Penyebab dan keberhasilan dan Kegagalan Berwirausaha}

Keberhasilan wirausaha dalam mengelola usahanya dapat disebabkan oleh beberapa faktor antara lain:

1. Kemampuan wirausaha mengidentifikasi kebutuhan dan keinginan pasar terhadap prduk/jasa dihasilkannya

2. Kemampuan wirausaha terebut dalam memproduksi barang/jasa yang dibutuhkannya

3. Kemampuan wirausaha tersebut dalam menerapkan manajemen yang baik meliputi manajemen produksi, manajemen pemasaran, keuangan , MSM, Pengelolaan Administrasi.

4. Kemampuan wirusaha dalam menjalin kerjasama baik internal maupun eksternal publik, khususnya terhadap perusahaan yang erat hubungannya dengan usaha yang dikelola.

5. Kemampuan wirausaha dalam memberikan pelayanan yang memuaskan pelanggan.

Menurut Sadono Sukirno et al. (2004:375), faktor-faktor kegagalan berwirusaha dapa dibedakan menjadi dua yaitu: 
1. Sebelum memiliki usaha

a. Memulai usaha tanpa penelitian dan perencanaan

b. Kesalahan memilih lokasi usaha

c. Tidak cukup modal dan alokasi yang tepat

d. Kesalahan menilai dan mengambil alih perusahaan

2. Kesalahan waktu menjalankan perusahaan
a. Manajemen uang tunai tidak efisien
b. Manajemen kredit yang lemah
c. Kesalahan meminjam tanpa pertimbangan
d. Kesalahan perputaran stock
e. Kesalahan menggunakan ruang dagang
f. Terlalu banyak membeli untuk memperbaiki tujuan
f. Pemborosan dalam hiasan dan belanja memperbaiki toko

g. Kegagalan dalam menyimpan catatan perusahaan

h. Mutu jasa menurun

\section{Rangkuman}

1. Wirausaha merupakan orang yang mampu mengkombinasikn berbagai faktor produksi untuk menciptakan sesuatu yang baru dan memiliki nilai tambah melalui sebuah proses yang disebut kewirausahaan.

2. Karakter-karakter yang paling dibutuhkan untuk mendukung munculnya seorang wirausaha yang berpeluang sukses tersebut, yaitu : 

(1) Daya gerak (drive)
(2) Kemampuan untuk berpikir
(3) Kemampuan membina relasi
(4) Mampu menyampaikan gagasan
(5) Keahilian Khusus
(6) Bukan sekedar tumpangan hidup

Pertanyaan untuk diskusi

1. Mengapa kewirausahaan perlu diperlajari dan dikembangkan

2. Mengapa kewirausahaan penting bagi perekonomian suatu bangsa

3. Sebutkan dan Jelaskan jenis-jenis wirusaha

4. Karekteristik apa yang membedakan wirausaha dan non wirausaha

5. Jelaskan bentuk wirausaha yang dijalankan oleh UMKM

Tugas

1. Perhatikan lingkungan usaha di sekitar saudara, kemudian identifikasin bentuk kewirausahaan yang dijalankan oleh pemilik usaha 


\section{BAB II \\ INOVASI}

Tujuan Pembelajaran:

Setelah mempelajari bab ini calon wirausaha diharapkan:

1. Dapat menjelaskan Arti Inovasi

2. Dapat menjelaskan Karekteristik Inovasi

3. Dapat menjelaskan Jenis-jenis inovasi

4. Menjelaskan Atribut Inovasi

5. Strategi dalam berinovasi

\subsection{Pengertian Inovasi}

Inovasi merupakan kemampuan untuk mengimplementasikan ide-ide kreatif tersebut terhadap permasalahan dan peluang yang ada untuk meningkatkan dan memperkaya kehidupan seseorang. Inovasi juga merpakan introduksi dari sebuah new technology yang berhasil secara ekonomi atau kombinasi baru dari teknologi yang ada untuk menciptakan perubahan drastis dalam hal value/price relationship yang ditawarkan kepada customer atau user (De Meyer dan Grag, 2005:12). Dari defenisi tersebut De Meyer dan Garg (2005) menyebutkan lima komponen penting yang patut kita perhatikan yaitu:

1. Customer atau user. Inovasi terjadi jika customer atau user merasa yakin bahwa ada perubahan drastis dalam apa yang 
mereka kenal sebagai value bagi price. Customer menunjuk pada perusahaan, sedangkan user adalah pekerja.

2. Inovasi mempengaruhi value/price relationship. Inovasi mencakup produk, services, sistem, dan proses. Tapi yang paling berpengaruh adalah inovasi produk.

3. Inovasi punya hubungan dengan new technology. Karena itu kita tidak membatasi inovasi kepada perubahanperubahan teknologi. Kita justru menganggap tipe-tipe redefinisi kreatif dari value proposition sebagai true innovation. Creative breakthrough menjadi satu inovasi jika ia memimpin pada kesuksesan secara ekonomi kepada firm.

Dalam inovasi perlu dibedakan antara sukses dibidang teknis, komersial, dan ekonomi. Sukses dibidang teknis artinya dapat menerjemahkan mimpi atau ide dalam bentuk produk, layanan, sistem, atau proses. Inovasi memang merupakan aksi yang penuh resiko. Tetapi ada prinsip-prinsip dasar yang kalau diikuti dengan baik sangat menolong untuk terhindar dari resiko-resiko tersebut, misalnya perusahaan harus mempunyai kepemimpinan yang kuat. (De Meyer da Garg, 2005). Perusahaan harus didukung oleh kreativitas karena inovasi selalu dimulai dengan kreativitas. Organisasi bertugas menciptakan lapangan lingkungan kerja yang memicu karyawan berani menjadi keratif. Misalnya, menciptakan pola 
kerja dalam kelompok biasanya lebih kreatif dibanding secara individu.

Dalam buku berjudul Change, Kasali (2005) menekankan pentingnya perubahan, yang merupakan sebuah drama kehidupan yang memberikan banyak ketakutan, sekaligus harapan. Jika ketakutan itu dapat dikendalikan, ia akan berusaha menjadi sebuah energi yang membangkitkan kehidupan yang kita sebut mukjizat. Penggalan kalimat yang kita kutip tadi mengandaikan pentingnya inovasi bagi suatu organisasi.

Sejak tahun 1930, perkembangan inovasi telah berubah, Rothwell (1994) membagi evolusi inovasi dalam 5 generasi yaitu:

\begin{tabular}{|c|c|}
\hline $\begin{array}{l}\text { 1. First Generation } \\
((\text { Innovation }(1 G)\end{array}$ & $\begin{array}{l}\text { Tekanan pada teknologi } \\
\text { Industrial Revolution }\end{array}$ \\
\hline $\begin{array}{l}\text { 2. Second Generation } \\
\text { Innovation }(2 G)\end{array}$ & $\begin{array}{l}\text { Tekanan pada kebutuhan } \\
\text { (need) } \\
\text { Dari market ke customer } \\
\text { focus }\end{array}$ \\
\hline $\begin{array}{l}\text { 3. Third Generation } \\
\text { Innovation }(3 G)\end{array}$ & $\begin{array}{l}\text { Couping Model (Tekanan } \\
\text { pada teknologi dan kebutuhan } \\
\text { atau need) }\end{array}$ \\
\hline $\begin{array}{l}\text { 4. Fourth } \\
(4 G)\end{array}$ & $\begin{array}{l}\text { Integrated Model ( a tight } \\
\text { couping of marketing, } R \& D \\
\text { activity, supplier and }\end{array}$ \\
\hline
\end{tabular}




\begin{tabular}{|c|c|}
\hline & customers) \\
\hline \multirow{3}{*}{$\begin{array}{l}\text { 5. Fithth Generation } \\
\text { Innovation }(5 G)\end{array}$} & $\begin{array}{l}\text { Strategic parthnerships with } \\
\text { supplier and customer, } \\
\text { mengggunakan } \\
\text { systems }\end{array}$ \\
\hline & $\begin{array}{l}\text { Menggunakan collaborative } \\
\text { marketing and research }\end{array}$ \\
\hline & $\begin{array}{l}\text { Faster, more efficient product } \\
\text { development }\end{array}$ \\
\hline
\end{tabular}

Allen (2010) menyatakan beberapa pengertian inovasi yakni antara lain:

a. Inovasi merupakan aktivitas (kegiatan) imajinatif untuk menghasilkan produk yang murni (orsinil) sekaligus komersil. (institute for innovation and information productivity).

b. Inovasi berkaitan dengan proses komersialisasi atau ekstraksi nilai dari ide (Rogers, 1998, the university of Melbourne)

Suryana dan Bayu (2010) menyatakan bahwa inovasi merupakan sesuatu yang dapat diimplementasikan dan juga menghasilkan nilai plus (tambah) yang dimiliki oleh sumber daya manusia.

Kotler (1996) menyatakan bahwa inovasi sebagai sesuatu yang berkenaan dengan barang atau jasa, atau ide yang 
dirasakan oleh seseorang. Inovasi produk dan juga inovasi manajemen dapat dilakukan didalam suatu perusahaan.

West \& Far (Ancok,2012:34), menyatakan bahwa Inovasi adalah pengenalan dan penerapan dengan sengaja gagasan, proses, produk, dan prosedur yang baru pada unit yang menerapkannya sehingga memberikan profit untuk masyarakat, organisasi, perusahaan atau individu.

Inovasi merupakan faktor utama di balik penciptaan nilai, kemakmuran ekonomi dan pertumbuhan lapangan kerja. Inisiatif ini dapat berlangsung pada beberapa tingkat perusahaan, regional dan nasional - dan menyebabkan bisnis baru serta peningkatan daya saing bagi mereka yang sudah mapan.

Inovasi merupakan salah satu kunci keberhasilan perusahaan, sebab perusahaan harus mampu berinovasi baik dalam wujud maupun produk, layanan ataupun sistem. Berinovasi secara efektif mendorong proses pengelolaan pengetahuan yang mengindahkan etika, nilai-nilai tambah bagi pra stokeholders dan tentunya akan membangun wisdom bagi perusahaan. Output dari inovatif tidak harus berupa produk ataupun layanan, namun dapat berupa peningkatan produktivitas proses transformasi satu input (masukan) menjadi keluaran.

Menurut Weiss \& Legrand (2011) menyatakan bahwa proses inovasi harus menghasilkan keluaran bernilai bagi organisasi. Inovasi diarahkan pada pencapaian luaran yang 
berkesinambungan (sutainable outcome) yang dapat meningkatkan apa dan cara orang melakukannya.

Dalam berinovasi, perusahaan perlu mempertimbangkan pengelolaan resiko, yang tidak berarti menghentikan proses inovasi. Fakta menunjukkan bahwa pemimpin perusahaan yang tidak berani mengambil resiko dan tidak berani berubah adalah penyebab perusahaan menjadi tertinggal. Nystrom (1990) menggarisbawahi bahwa pada dasarnya defenisi inovasi memiliki defenisi yang sama, yakni berhubungan dengan idea/knowledge yang dibuat menjadi produk, proses dan sistem baru untuk meningkatkan keunggulan perusahaan ataupun organisasi dalam bersaing dan memenuhi perubahan kebutuhan para pelanggan.

Dalam lingkungan bisnis yang mengglobal dan kompetitif, perusahaan harus mampu berinovasi agar bertahan dan bertumbuh. Banyak perusahaan di dunia antara lain 3M, Microsoft, Samsung, Toyota dan produk Unilever saling berinovasi dan menawarkan produk yang membuat nilai tambah bagi stakeholdernya. Banyak perusahaan mengalami kemunduran kegagalan karena tidak mampu bersaing, mereka tidak mampu belajar secara cepat dan tepat untuk berinovasi.

Beberapa perusahaan sukses dan inovatif di dunia antara lain Microsoft, Apple, Intel dan Google, Samsung selalu berupaya menciptakan produk-produk baru. memiliki nilai pasar (market value) yang jauh lebih tinggi dari nilai fisik mereka. Perusahaan yang jauh lebih tinggi dari nilai fisik 
mereka. Perusahaan tersebut berpacu dalam inovasi. “ Intangible assets" dapat dikatakan sangat berharga bagi perusahaan. Nonaka (1994) mengemukakan bahwa inovasi adalah sebuah proses yang dijalankan oleh suatu organisasi dalam menciptakan dan aktif mengembangkan pengetahuan baru untuk memecahkan masalah. Menurut Jorna \& Waalkens (dalam Jorna, 2006:19), inovasi berkaitan dengan desain baru (desain yang belum pernah ada sebelumnya) serta diwujudkan dalam bentuk produk, layanan, konstruk, proses atau sistem.

Banyak pelaku bisnis di Indonesia yang menawarkan berbagai produk dan jasanya lewat on line (daring). Perusahaan berbasis on line selalu menawarkan produk dan layanan inovatif untuk menarik pelanggan dan pembeli baru denga jangkauan luas (tanpa batas). Mengacu pada konsep Schumpeter yang menekankan pada destruktif kreatif, banyak penelitian yang memaparkan inovasi berdasarkan dampaknya pada kemampuan perusahaan. Schumpeter (1934) mengaitkan suatu inovasi dengan penciptaan nilai bagi para usahawan, yang akhirnya berdampak pada kinerja perusahaan, yang dicerminkan oleh besaran finansial/ekonomi. Agar perusahaan mampu berinovasi secara efektif, para pemimpinnya harus memiliki kecerdasan berinovasi yang menurut Weiss \& Legrand (2011) adalah kemampuan untuk memperoleh ilham (insights) dalam menghadapi persoalan yang kompleks atau peluang-peluang yang menjanjikan serta menemukan solusi yang baru yang tak terpikirkan sebelumnya namun dapat 
diimplementasi. Mereka mengemukakan bawa proses berpikir inovatif terdiri dari empat aspek:

a. Pengerangkaan (framework) yaitu aktivitas yang berupaya memahami persoalan-persoalan bisnis berdasarkan kerangka tertentu.

b. Redefinisi yaitu mendalami faktor-faktor yang mendasari persoalan-persoalan.

c. Pengembangan gagasan yang menemukan satu atau lebih solusi inovatif pada persoalan.

d. Pengimplementasian perencanaan yaitu mengevaluasi gagasan-gagasan yang terbaik dan sekaligus memitigasi resiko

Berkaitan dengan inovasi, Kim \& Mauborgne (2005) mengemukakan bahwa menciptakan sesuatu dengan nilai baru (a new learning value curve) dapat dilakukan melalui perekonstruksian nilai pembeli melalui empat langkah sebagai berikut:

a. Eleminasi (Eliminate) menekankan pada faktor-faktor suatu produk/layanan/sistem yang dapat dieleminasi tanpa membawa dampak yang signifikan.

b. Kurangi (Reduce) menekankan pada faktor-faktor pada suatu produk/layanan/sistem yang dapat dikurangi sedikit atau cukup banyak dibawah standar industri dan tidak berimpliksi negatif karena memang tidak menjadi keinginan pembeli. 
c. Tingkatkan (Raise) menekankan pada faktor-faktor pada produk/layanan/sistem yang seharusnya ditingkatkan agar melebihi standar industri yang ada.

d. Ciptakan (create) menekankan pada faktor-faktor pada produk/layanan/sistem yang belum opernah ada dalam industri dan harus diciptakan.

Mengacu pada empat pernyataan diatas, maka kerangka empat tindakan untuk menciptakan produk/layanan/sistem yang inovatif baru dapat digambarkan sebagai berikut:

Mengurangi

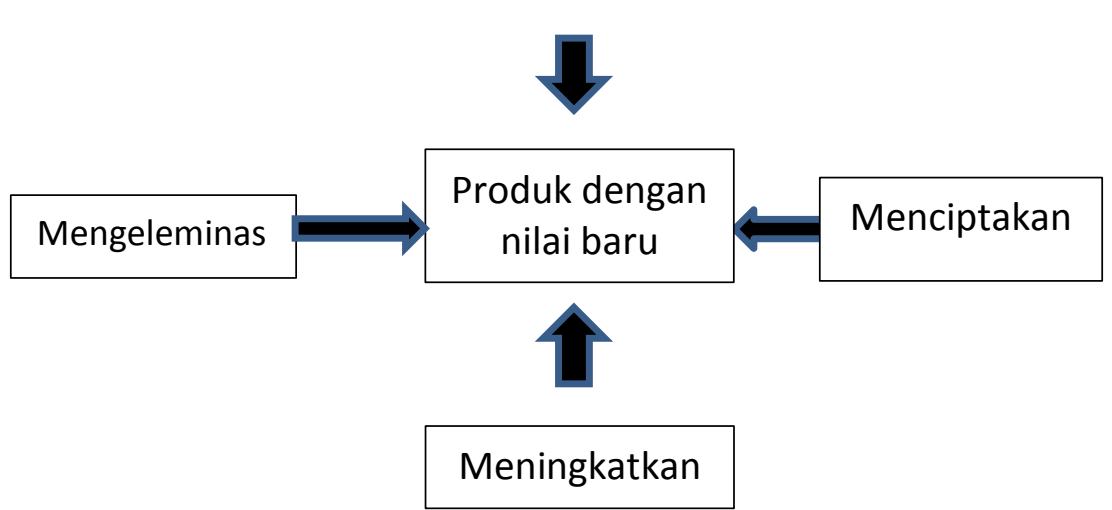

Gambar1. Kerangka Empat Tindakan

(Sumber: Kim \& Mauborgne, 2005)

Dalam buku Blue Ocean Strategy, Kim dan Mauborgne mengungkapkan bahwa perusahaan harus berinovasi agar menghasilkan produk atau jasa yang unik, menonjol serta tidak memiliki pesaing yang relevan. Dengan 
tidak memiliki pesaing yang relevan, perusahaan tersebut dapat "Melenggang" seolah bak sebuah kapal yang berlayar sendiri di laut yang tenang, dan tak berombak. Keunikan yang ditampilkan harus " khas" dan tak tertirukan baik dalam bentuk, sistem atau layanan.

Henderson dan Clark (1990) mengklasifikasikan dalam dua dimensi yaitu:

a. Horizontal: menjelaskan dampak inovasi pada komponenkomponen produk

b. Vertikal: mengacu pada dampak inovasi pada hubunganhubungan antar komponen produk.

Clark (1985) mengemukakan komponen berfungsi sebagai pembeda yang tampak secara fisik dari suatu produk yang mewujudkan desain utama konsep serta menunjukkan suatu fungsi yang terdefinisikan secara baik. Suatu contoh, pada produk kipas angin; motor (Dinamo) adalah komponen yang dirancang untuk memberi tenaga agar kipas berputar. Pemilihan penggunaan motor listrik tersebut membangun suatu konsep utama rancangan suatu produk. Dengan demikian, motor listrik adalah komponen aktual yang mengimplementasikan sifat nyata dari rancangan konseptual.

Permasalahan dalam inovasi pada umumnya adalah sejauh mana pentingnya inovasi tersebut berperan dalam keberhasilan suatu perusahaan. Menurut Arnoud De Meyer dan Sam Garg (2005) probabilitas keberhasilan ekonomi dari sebuah inovasi sebesar 20-30 persen dari seluruh proyek yang 
di organisir. Berdasarkan angka tersebut berarti suatu inovasi memerlukan ketekunan agar dapat berhasil. Banyak ide-ide cemerlang yang muncul dari penelitian yang unggul dan dari pengalaman para manager yang mempunyai performa tinggi. Dengan demikian, untuk memunculkan inovasi di antaranya diperlukan sifat kepemimpinan (leadership).

Perkembangan atau inovasi dapat dilakukan perusahaan. Inovasi dapat tercipta dengan cara perhatian yang serius terhadap kebutuhan pasar (customer needs). Tahap dari inovasi adalah capture. Pada tahap ini, kita memastikan untuk mendapat manfat dari inovasi yang silakukan serta bagaimana menilai cara-cara kita mengatur, mengelola dan menggunakan inovasi untuk mendorong proses belajar dan memungkinkan kita melakukannya lebih baik. Menurut Tidd \& Bessant (2009), manfaat dari hasil inovasi dapat dilihat mellaui hubungan antara jenis pengetahuan, inovasi, dan kinerja perusahaan. Ketika suatu organisasi ingin mendapatkan manfaat dari inovasi, hal yang perlu dipahami adalah perusahaan adalah nilai atau value yang bermanfaat bagi pelanggan. Dalam menciptakan value, perusahaan dapat memilih salah atu pendekatan strategis, yaitu innovation leadership. Perusahaan menjadi yang pertama masuk ke pasar berdasarkan technological leadership atau innovation followership.

Inovasi tidak hanya terkait dengan suatu penemuan baru dan valued added bagi suatu konsumen, namun juga 
merupakan suatu proses pembelajaran, dengan inovasi yang dapat dipelajari, dipahami dan dikembangkan untuk menambah value yang sudah ada. Berdasarkan penelitian dan pengalaman, Tidd \& Bessant (2009) menyatakan bahwa terdapat tiga poin penting dalam strategi inovasi, yaitu:

1. Posisi perusahaan-produk, proses teknologi, dan sistem inovasi nasional

2. Jalur teknologi yang dipilih, dan

3. Proses organisasi yang dilakukan oleh perusahaan untuk menggabungkan strategi pembelajara lintas fungsi dan divisi.

Inovasi Model Bisnis (BMI) mengacu pada pembuatan atau reinvention dari bisnis itu sendiri, sedangkan inovasi biasanya lebih terlihat, dalam bentuk produk baru atau menawarkan layanan . Selain itu, hasil inovasi model bisnis dalalm tipe yanng sama sekali berbeda dari perusahaan persaingannya tidak hanya berupa proporsi niai penawaran, tetapi sejalan dengan rumus laba, sumber daya, dan proses untuk meningkatkan proporsi nilai, mendapat segmen pasar dan mengasingkan pesaing. Alexander Ostewalder dalam tesis doktornya menyelidiki ontologi model bisnis dan mengembangkan model bisnis kanvas sebagai alat untuk desain sistematis atau desain model bisnis. Kesuksesan model bisnis sistematis atau desain model bisnis. Kesuksesan model bisnis desain menurut Osterwalder arus mempertimbangkan 9 unsur 
yaitu Customer, segments, value propositions, distribution channels, key partners, dan cost structure.

Rinella (2007) dalam Vibznews, menyatakan bahwa inovasi bukanlah sesuatu yang terjadi hanya satu kali, melainkan sebuah proses yang harus dikelola, diukur, dan dilakukan secara kontinu pada seluruh produk, layanan, dan fungsi bisnis pada suatu perusahaan. Perusahaan yang sukses dan memiliki kinerja bagus memanfaatkan model bisnis maupu teknologi untuk berinovasi. Model bisnis meliputi bagaimana sebuah perusahaan menciptakan, menjua dan memberikan value kepada pelanggannya. Tiga area perubahan model bisnis yang dapat mendorong inovasi adalah sebagai berikut:

1. Value propositon, yaitu apa yang dijual dan diberikan kepada pasar contoh: Pepsodent whitening-Unilever yang menyatakan dapat memberi dua manfaat sekaligus, yaitu mengembalikan warna putih alami gigi dan menjaga gigi tetap sehat dan kuat. Sebelumnya, value propositon hanya menjaga gigi tetap sehat dan kuat.

2. Supply chain, yaitu bagaimana suatu value diciptakan dan diberikan kepada pasar. Ipod Apple misalnya, hard drive dibuat oleh Toshiba Jepang, kemudian assembly dilakukan di China. Sementara itu beberapa chip disupplai oleh perusahaan Amerika Serikat dan Taiwan.

Target pelanggan, yaitu kepada siapa value tersebut diberikan. Misalnya, Bank Mandiri kini melirik segmen kartu kredit korporasi. 
Menurut Agus Nggermanto (2010) dalam website APIQ menuliskan bahwa inovasi yang berdampak paling besar dalam bisnis adalah inovasi pada bisnis model. Berikut ini adalah beberapa model bisnis yang sedang fenomenal:

1. Model bisnis franchise dengan keunggulan nama besar, network dan kelenturan, misalnya MC Donald KFC dan Coca Cola

2. Model bisnis Freemium, memberikan layaan atau produk free kepada pelanggannya, pendapatan diperoleh melalui iklan sebagai contoh pendapatan Google adalah dari iklan yang dibayar pemasang dengan hitungan pay per click

3. Model bisnis syariah dapat kita lihat pada bidang perbankan misalnya gadai syariah.

Berikut ini adalah contoh model bisnis abad 21 sebagai berikut:

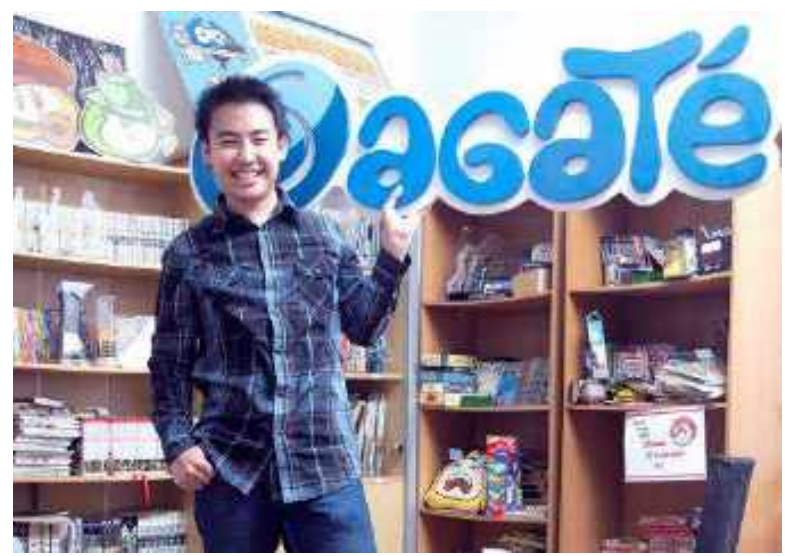




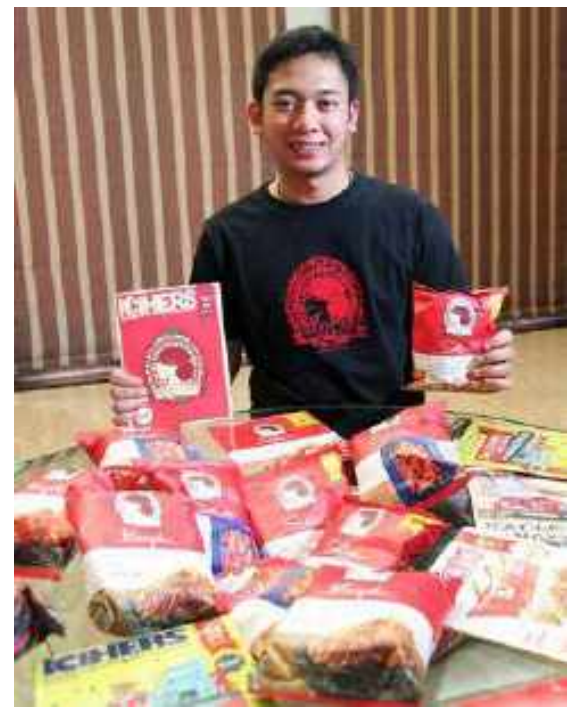

\section{Reza Nurhilman}

with Maicih

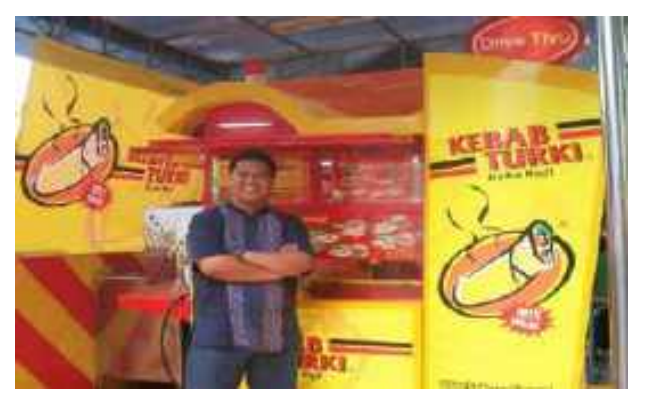

Hendi Setiono with Kebab Turki 


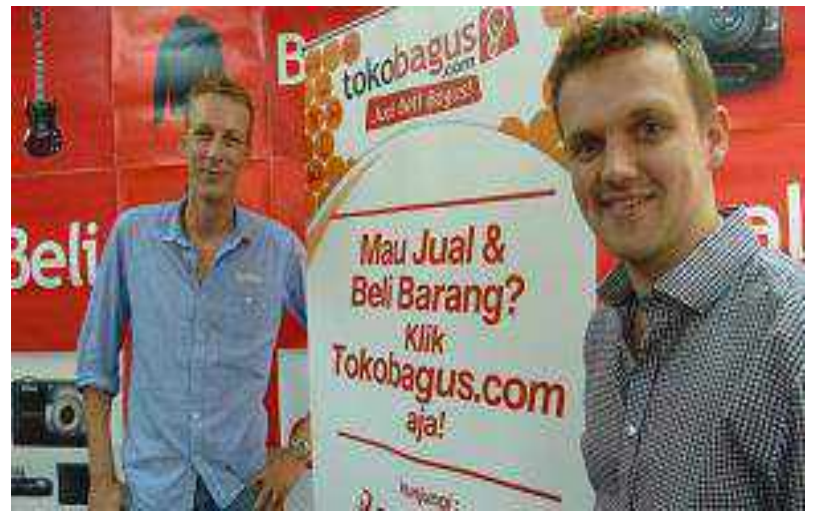

\section{Alex \& Fabrice with Toko Bagus}

\subsection{Karakteristik Inovasi}

Cepat atau lambat penerimaan inovasi oleh masyarakat sangan tergantung pada karakteristik inovasi itu sendiri. Karakteristik inovasi yang mempengaruhi cepat lambat penerimaan informasi Everett M. Rogers (2003), sebagai berikut:

1. Keunggulan relatif (relative advantage) - Keunggulan relatif yaitu sejauh mana inovasi dianggap menguntungkan bagi penerimanya. Tingkat keuntungan atau kemanfaatan suatu inovasi dapat diukur berdasarkan nilai ekonominya atau dari faktor sosial faktor sosial, kesenangan, kepuasan, makin menguntungkan bagi penerima makin cepat tersebarnya inovasi.

2. Kompatibilitas (compatibility) - Kompatibel ialah tingkat kesesuaian inovasi 
ddengan nilai, pengalaman lalu, dan kebutuhan dari pe nerima.

3. Kerumitan (complexity)-Kompleksitas ialah, tingkat kesukaran untuk memahami dan menggunakan inovasi bagi penerima, dan menggunakan inovasi bagi penerima. mudah digunakan oleh penerima akan cepat tersebar, sedangkan inovasi yang sukar dimengerti atau sukar digunakan oleh penerima akan lambat proses penyebarannya.

4. Kemampuan diujicobakan (triability) - Kemampuan untuk diujicobakan adalah di mana suatu inovasi dapat dicoba atau tidaknya suatu inovasi oleh penerima.

5. Kemampuan untuk diamati (observability)-Yang dimaksud dengan dapat diamati ialah mudah atau tidaknya pengamatan suatu hasil inovasi. Suatu inovasi yang hasilnya mudah diamati akan makin cepat diterima oleh masyarakat, dan sebaliknya bila sukar diamati hasilnya, akan lama diterima oleh masyarakat.

\subsection{Jenis-jenis Inovasi}

Menurut Nasution (2005), ada tiga jenis inovasi, yakni :

1. Inovasi Produk

Didefinisikan sebagai produk atau jasa baru yang diperkenalkan ke pasar untuk memenuhi kebutuhan pasar. Lebih lanjut dapat didefinisikan sebagai proses memperkenalkan teknologi baru untuk digunakan. Hasil dari proses ini berupa pengenalan barang dan jasa baru 
yang dapat digunakan untuk meningkatkan keuntungan perusahaan.

2. Inovasi Proses

Inovasi proses adalah suatu elemen baru yang diperkenalkan dalam operasi produk dan jasa dalam perusahaan, seperti materi bahan baku, spesifikasi tugas, mekanisme kerja dan informasi, maupun peralatan yang digunakan untuk memproduksi produk atau jasa.

3. Inovasi Administrasi

Inovasi ini sangat berkaitan dengan perubahan dalam metode operasi bisnis yang dapat memanfaatkan perubahan tersebut secara efektif dalam struktur dan kebijaksanaan organisasi, metode kerja dan prosedur lainnya untuk memproduksi, membiayai dan memasarkan produk atau jasa. Inovasi administrasi turut melibatkan perubahan yang berpengaruh terhadap kebijakan-kebijakan organisasi, alokasi sumber daya dan faktor-faktor lain yang berkaitan dengan struktur sosial organisasi yang secara langsung maupun tidak langsung berkaitan dengan kegiatan dasar organisasi.

Inovasi produk bergerak selangkah lebih maju dengan mengkonversikan penerapan untuk menghasilkan produk yang dapat dipasarkan. Inovasi produk sering dikaitkan dengan teknologi, karena dengan adanya teknologi 
memudahkan perusahaan untuk mengembangkan ide yang akan membantu tercapainya tujuan perusahaan (Kevin, 2008).

Menurut Lamb et.al (2001) Inovasi produk adalah strategi pemasaran yang memerlukan penciptaan produk baru yang dapat dipasarkan, proses merubah aplikasi untuk teknologi baru ke dalam produk yang dapat dipasarkan. Menurut Kotler dan Armstrong (2001) Inovasi produk adalah tiap perusahaan harus mengembangkan produk baru. Inovasi produk baru membentuk masa depan perusahaan. Produk pengganti harus diciptakan untuk mempertahankan atau membangun penjualan. Perusahaan dapat menambah produk baru melalui akuisisi atau inovasi produk baru.

Pengertian inovasi produk menurut Saladin dan Oesman (2002) meliputi :

1. Produk baru yaitu

a. Produk yang benar-benar inovatif dan benar-benar unik

b. Produk pengganti yang benar-benar berbeda dari produk yang sudah ada

c. Produk imitative, yaitu produk yang baru bagi perusahaan tertentu tapi bukan baru di dalam pasar

d. Produk yang menggunakan bahan baku baru sama sekali

2. Inovasi produk

a. Riset pemasaran

b. Rekayasa

c. Desain 
3. Modifikasi produk, yaitu memperbaiki produk yang sudah ada yang meliputi quality, feature dan style yang tujuannya meningkatkan penjualan. Modifikasi produk menciptakan tiga dimensi, yaitu
a. Perbaikan mutu (Quality Improvement)
b. Perbaikan ciri-ciri khas (Feature Improvement)
c. Perbaikan gaya (Style Improvement)

4. Merchandising, yaitu semua aktivitas perencanaan baik dari produsen maupun pedagang perantara yang dimaksudkan untuk menyesuaikan antara produk-produk yang dihasilkan dengan permintaan pasar.

Menurut Buchari (2004), tujuan inovasi produk yaitu:

1. Untuk memenuhi keinginan nasabah yang belum puas

2. Untuk menambah omzet penjualan

3. Untuk memenangkan persaingan

4. Untuk mendayagunakan sumber-sumber produksi

5. Untuk meningkatkan keuntungan dengan pemakaian bahan yang sama

6. Untuk mendayagunakan sisa-sisa bahan

7. Untuk mencegah kebosanan nasabah

8. Untuk menyederhanakan produk, pembungkus 


\subsection{Atribut Inovasi}

Menurut Rogers dalam LAN (2007:116) mengatakan bahwa inovasi mempunyai atribut sebagai berikut:

1. Keuntungan Relatif

Sebuah inovasi harus mempunyai keunggulan dan nilai lebih dibandingkan

dengan inovasi sebelumnya. Selalu ada sebuah nilai kebaruan yang melekat dalam inovasi yang menjadi ciri yang membedakannya dengan yang lain.

2. Kesesuaian

Inovasi juga sebaiknya mempunyai sifat kompatibel atau kesesuain dengan inovasi yang digantinya. Hal ini dimaksudkan agar inovasi yang lama tidak serta merta dibuang begitu saja, selain karena alasan faktor biaya yang sedikit, namun juga inovasi yang lama menjadi bagian dari proses transisi ke inovasi terbaru. Selain itu juga dapat memudahkan proses adaptasi dan proses pembelajaran terhadap inovasi itu secara lebih cepat.

3. Kerumitan

Dengan sifatnya yang baru, maka inovasi mempunyai tingkat kerumitan yang boleh jadi lebih tinggi dibandingkan dengan inovasi sebelumnya. Namun demikian, karena sebuah inovasi menawarkan cara yang lebih baru dan lebih baik, maka tingkat kerumitan ini pada umumnya tidak menjadi masalah penting. 


\section{Kemungkinan Dicoba}

Inovasi hanya bisa diterima apabila telah teruji dan terbukti mempunyai keuntungan atau nilai dibandingkan dengan inovasi yang lama. Sehingga sebuah produk inovasi harus melewati fase "uji publik", dimana setiap orang atau pihak mempunyai kesempatan untuk menguji kualitas dari sebuah inovasi.

5. Kemudahan diamati

Sebuah inovasi harus juga dapat diamati, dari segi bagaimana sebuah inovasi bekerja dan menghasilkan sesuatu yang lebih baik.

\section{Contoh Inovasi}

Pembuatan produk PC Tablet Wakamini buatan negeri, Seolah tidak ingin ketinggalan dengan gadget baru seperti produk lain. Indonesia meluncurkan sebuah inovasi baru membuat produk PC Tablet Wakamini. Wakamini terbukti mampu bersaing dengan suatu produk-produk dari luar. Zyrex ialah sebagai produsen suatu peralatan komputer Indonesia yang memproduksi PC Tablet Wakamini MP 1291 series Multi Touch dan Wakatobi Mini 963 yang diklaim 100\% buatan Indonesia dengan yang harga berkisar 3 juta rupiah.

Masyarakat khususnya para pelanggan, menginginkan mendapat suprise dari perusahaan-perusahaan inovatif melalui penciptaan produk-produk yang bernilai tambah sebagai hasil dari proses pengembangan produk yang kreatif. 
Inovasi dalam bentuk sistem banyak berkaitan dengan teknologi misalnya informasi mengenai jadwal penerbanan, harga serta promosi-promosi dewasa ini mudah diakses melalui internet. Perusahaan-perusahaan penerbangan Air Asia misalnya memungkinkan pelanggan memesan tiket, melakukan pembayaran dan melakukan Chek in in secara online. Calon penumpang dapat memilih sendiri nomor tempat duduk, serta dapat memesan makan di pesawat jika dikehendaki lewat online. Hal ini merupakan nilah tambah sendiri untuk Air Asia. Namun, jika perusahaan penerbangan lain juga menawarkan layanan yang serupa, maka hal tersebut tidak merupakan keunggulan. Maka Air Asia perlu berinovasi lagi dalam hal lain, misalnya kenyamanan dan keamanan penerbangan dan sebagainya. Secara singkat dapat disimpulkan bahwa inovasi dapat berbentuk produk, layanan proses atau system ataupun gabungan ketiganya. Inovasi yang khas dan unik yang membedakan suatu produk dari yang lain dan akan memberikan nilah tambah bagi pelanggan tentu akan menarik para pasar sasaran.

Samsung dan galaxy Note-nya (Note 3, Note 4, Note 4, Note 5 dan seterusnya) yang sebenarnya perubahan yang ada pada tipe-tipe tersebut tidak fundamental, namun samsung mempersiapkan tipe-tipe lain dengan keunggulan di atas para pesaingnya, dengan tetap memperhatikan keinginan dan kebutuhan pasar sasara mereka. 


\subsection{Strategi dalam Inovasi}

Porter (1980) mengemukakan empat kelompok strategi dalam inovasi yaitu:

\section{a. Focus Differentation}

Jika diferensiasi suatu produk/layanan difokuskan pada pasar tertentu, misalnya mobil Ferrari dan Porche menyasar kelompok pasar yang sangat khusus/fokus yaitu para penggemar mobil mewah, " pembalap" dari kalangan the haves dan sangat peduli dengan kualitas, kebaruan yang sangat unik, baik dalam desain, kualitas mesin, interiror dan lain sebagainya.

b. Differentiation

yaitu yang menciptakan produk untuk pasar tertentu, misalnya golongan menengah keatas (eksekutif muda) serta menyukai keindahan keanggunan desain, mutu mesin dan sebagainya. Contoh produk mobil Mercedex, BMW, Lexus

c. Overall Cost Leadership (OCL)

Sasarannya yaitu suatu kelompok pasar menengah, yang peduli kualitas mesin serta tidak terlalu menginginkan suatu kemewahan misalnya mobil produksi General Motors, Ford, Toyota

d. Focus Cost

Menyasar pasar menengah kebawah yang melihat mobil lebih pada fungsinya. Misalnya Proton, Saga. 
Rangkuman

1. Inovasi merupakan salah satu kunci keberhasilan perusahaan, sebab perusahaan harus mampu berinovasi baik dalam wujud produk, layanan atau sistem yang bernilai tambah dan berkualitas bagi para pemangku kepentingan, dan inovasi tersebut lebih cepat dibandingkan pesaing.

2. Perusahaan harus menghasilkan inovasi yang efektif untuk meraih sukses.

3. Tanpa melakukan inovasi sebuah perusahaan akan sulit maju, khususnya perusahaan yang produknya berkaitan dengan fashion, teknologi dan jasa.

4. Inovasi merupakan kemampuan untuk mengimplementasikan ide-ide kreatif tersebut terhadap permasalahan dan peluang yang ada untuk meningkatkan dan memperkaya kehidupan orang. Dalam hal ini sebuah inovasi haruslah dapat diterima oleh pasar

Pertanyaan untuk diskusi

1. Mengapa Kreativitas penting dalam Kewirausahaan

2. Sebutkan dan jelaskan jenis-jenis inovasi dan berikan contohnya

3. Sebutkan dan jelaskan jeni-jenis wirausaha

Tugas

Berikan contoh inovasi pengembangan kewirausahaan di abad ke -21 


\section{BAB III BERPIKIR PERUBAHAN}

Tujuan Pembelajaran Setelah mempelajari bab ini, calon wirausaha diharapkan:

1. Memahami tentang pentingnya perubahan dan peranan mindset (pola pikir)

2. Menjabarkan perubahan pola pikir

3. Menjelaskan pola pikir wirausaha

4. Mengenalkan teori kecerdasan Finansial

\subsection{Pentingnya Perubahan dan Peranan Mindset (Pola Pikir)}

Pola pikir kita (kita kadang-kadang disebut paradigma kita) adalah jumlah total keyakinan, nilai, identitas, harapan, sikap, kebiasaan, keputusan, pendapatan, dan pola pola pemikiran kita tentang diri kita sendiri, orang lain, dan bagaimana kehidupan bekerja. Ini adalah saringan yang dengannya kita menafsirkan apa yang kita lihat dan alami. Pola pikir membentuk kehidupan dan menarik kepada diri hasilhasil yang merupakan refleksi pasti pola pikir itu. Apa yang dipercayai akan terjadi, benar-benar terjadi. Kita mendekati, bereaksi, dan pada kenyataan menciptakan dunia kita berdasarkan pola pikir individual kita sendiri. Pola pikir kita memberitahu kita bagaimana permainan hidup ini harus dimainkan, dan mengatur apakah kita memainkan nya secara 
berhasil atau tidak. Kita mungkin memiliki pola pikir, misalnnya yang memberitahu kita, "Kehidupan ini sangat keras, dan aku harus berjuang hanya sekedar untuk hidup paspasan." Atau kita mungkin memiliki pola pikir yang lebih positif, seperti, “Aku punya kemampuan yang hebat dan orangorang ingin bekerjasama denganku." Pikiran adalah magnet yang sangat kuat. Apapun yang diberitahukan pola pikir kita kepada kita adalah apa yang kita tarik, baik kita menyadarinya atau tidak! Jika Anda memiliki keyakinan bahwa, "Kehidupan ini sangat keras, dan aku harus berjuang hanya sekedar untuk hidup pas-pasan," misalnya, Anda tidak perlu menyadari akan keyakinan itu untuk mengalami perjuangan dalam hidup Anda.

Pada kenyataannya, jika Anda ingin melihat apa pola pikir Anda sebenarnya, Anda hanya perlu melihat hidup Anda dan ahsil-hasil Anda. Hasil yang kita peroleh sesuai dengan apa yang kita yakini. Jika kita tidak memeriksa pola pikir kita dan bertanya apakah pola pikir itu mendukung atau membatasi kita, kita beroperasi "secara otomatis." Kita tidak lagi memilih keyakinan dan pola pikir kita, tetapi keyakinan dan pola pikir itu menyebabkan kita menjalani hidup dengan cara tertentu. Kita menciptakan pola pikir kita sendiri, tetapi pada saat yang sama, pola pikir kita menciptakan diri kita. Jika kita tidak mempertanyakan keyakinan yang menyebutnya bahwa "kehidupan ini sulit," misalnya, kita akan terus berjuang bahkan tanpa mengetahui penyebabnya. Kita semua memiliki keyakinan lama yang tersembunyi. Banyak dari keyakinan itu 
diperoleh pada masa kanak-kanak dan tidak lagi berguna bagi kita atau mendukung keberhasilan kita. Ketika Alice mulai memeriksa pola pikirnya, ia menyadari ia memiliki keyakinan bahwa "Uang berasal dari kedua orangtua saya." Ketika ia masih kecil dan ingin es krim, mainan, atau boneka, dari orangtuanyalah uang berasal. Ketika remaja, dari orangtuanyalah uang tunjangan berasal. Ketika dewasa, ia sering menemukan dirinya dalam kesulitan financial dan terpaksa meminjam sejumlah besar uang kepada orangtuanya.

'Joel Arthur Barker menulis dalam Paredigma “ Mengabaikan kekuatan paradigma untuk memengaruhi pendapat Anda berarti menenpatkan diri Anda dalam resiko ketika menjajaki masa depan. Agar mampu membentuk masa depan, Anda harus siap dan mampu mengubah paradigm Anda." Pola pikir menggerakkan perilaku kita. Jika ingin melihat pola pikir Anda sendiri dan keluarga serta teman-teman Anda, cobalah mengadakan permainan kartu dengan keluarga selama liburan. Kemungkinan besar orang-orang akan melakukan di sekeliling meja kartu apa mereka lakukan dalam hidup mereka.

Apakah beberapa orang bersikap jemu? Kompetitif? Santai? Apakah mereka ingin menyelamatkan muka atau bersikap tenang, atau apakah mereka mengambil resiko menyonggung perasaan orang lain agar dapat mengendalikan dan mendominasi? Apakah mereka malu-malu atau menguasai? Bagaimana mereka memandang orang lain akan 
bertindak terhadap mereka? Apakah beberapa orang berpikir mereka akan dimanfaatkan atay dibuat tampak bodoh? Apakah mereka berpikir orang lain bodoh atau berprilaku buruk? Semua perilaku ini mencerminkan pola pikir tertentu, cara melihat diri sendiri, orang lain, dan dunia. Kita dapat mempercayai apapun yang kita percayai. Dan kita dapat menemukan banyak bukti untuk mendukung keyakinan atau pola pikir apapun yang kita pilih, jadi kita juga dapat memilih keyakinan yang memperkuat kita dan menggerakkan kita untuk maju. Kita mulai berhasil ketika kita memahami bahwa kita mempunyai sebuah plihan, karena pada saat itu, kita dapat mulai memilih keyakinan yang membawa kita kemana kita ingin pergi. William James, bapak psikologi moder, berkata . "Yakinlah bahwa hidup Anda berharga, maka keyakinan Anda akan menciptakan faktanya."

Agar berhasil, Anda perlu memahami pola pikir Anda. Anda harus membawanya ke tingkat sadar, memerhatikiannya dengan baik, dan melihat apakah ada sesuatu yang ingin Anda ubah. Jika tidak, keyakinan Anda yang tersembunyi akan mengendalikan Anda. Jika Anda tidak mengetahui pola pikir Anda, Anda tidak dapat melakukan apapun terhadapnya. Jika Anda ingin mengubah hasil-hasil Anda, Anda harus mengubah pola pikir Anda. Pergeseran pola pikir berarti berubah dari satu titik ke titik lain. Dalam Ilmu Sukses, ini berarti beralih dari satu pola pikir yang menghalangi keberhasilan ke cara berpikir yang mendorong dan menarik keberhasilan. Ketika menggeser 
pola pikir Anda, Anda beralih ke sebuah permainan baru dan seperangkat aturan yang baru. Ketika permainan Anda dan aturan berubah, seluruh dunia Anda mulai berubah. Anda mulai mengeluarkan energy yang berbeda, sehingga Anda menarik jenis orang-orang dan situasi yang berbeda ke dalam hidup Anda. Ketika Anda mentransformasi pemikiran Anda, Anda mentransformasi dunia Anda.

Oliver Wendel Holmes pernah berkata, "Pikiran manusia yang dibentangkan ke sebuah gagasan baru tidak pernah kembali ke dimensi asalnya." Banyak orang mengatakan mereka ingin mengubah hidup mereka. Mereka menghadiri ceramah pembicara motivasi atau membuat janji Tahun Baru dan menjadi sangat gembira dengan semua perubahan yang mereka lihat untuk diri mereka sendiri. Atau mereka pergi ke seminar atau membaca buku dan melihat bahwa mereka ingin mulai melakukan hal-hal secara berbeda. Mereka bahkan mungkin melakukan beberapa perubahan dalam beberapa minggu pertama. Tetapi kemudian energi mereka tampak berkurang. Antusiasme mereka merosot. Sebelum Anda mengetahui hal itu, mereka kembali ke dalam rutinitas lama mereka. Ketika ini terjadi, penyebabnya adalah mereka mencoba untuk memanipulasi akibat-akibat dari kehidupan mereka, dan bukannya mencari sebabnya. Mereka mencoba untuk mengubah hasil tanpa mengubah pola pikir mereka. Untuk memberikan hasil yang dramatis dan permanen, Anda harus mengubah cara berpikir. Jika tidak ada pergeseran 
pola pikir, setiap perubahan atau perbaikan hanya akan bersifat minimal dan/atau berjangka pendek.

\subsection{Perubahan Mindset (pola pikir)}

Apakah pola pikir dapat bisa diubah? Jawabnya "bisa". karena pola pikir merupakan hasil dari sebuah proses pembelajaran (learning), maka pola pikir dapat juga diubah (unlearning), dan di bentuk ulang (learning). Tentu saja ada pikiran-pikiran mudah dan sulit untuk diubah. Ada yang cepat dan ada yang membutuhkan waktu lama. Ada yang bisa kita ubah dengan kesadaran kita sendiri dan ada yang baru berubah setelah mengalami peristiwa tetentu. Ada pula pola pikir yang bisa kita ubah dengan bantuan para ahli, seperti psikolog, ahli mindset transformasi atau teraphis NLP (neuro linguistik program) dengan kata lain, prinsip-prinsip yang kita pakai berasal dari pemikiran yang sama. Pernyataan lain, bagaimana agar ada konsistensi antara pengetahuan dan tindakan? Ini tentu bukan perkara mudah oleh karna itu masih mungkin mengalami perubahan. Ada beberapa tips untuk merubah pola pikirantara lain

1. Tidak perlu takut bila anda bersentuhan dengan arus pikiran lain, apakah itu arus pikiran berbahaya, anda tidak perlu takut. Singkirkanlah sikap demikian dalam benak anda. Bila perlu, bacalah buku yang anda anggap extrem. Mengenal musuh lebih baik daripada tidak mengenalnya sama sekali. 
2. Usahakanlah untuk tidak menolak informasi yang bertentangan dengan keyakinan anda. Tidak ada salahnya kita memiliki informasi yang berbeda dengan keyakinan kita. Bila selama ini anda hanya menerima informasi sesuai dengan keyakinan anda, terimalah informasi baru sekalipun bertentangan dengan keyakinan anda. Pelajarilah informasi baru tersebut sebelum anda menerima atau menolaknya.

3. Bacalah buku-buku terpenting yang dapat merubah pola pikir kita dan belilah buku-buku tersebut sesuai dengan keuangan anda.

4. Bergaullah dengan orang-orang yang arus pemikiranya berseberangan dengan anda. Kita cenderung bergaul dengan orang-orang yang sepaham,sealiran atau yang status sosialnya sama dengan kita. Bergaullah dengan orangorang yang berbeda dengan keyakinan anda. kita dianjurkan untuk saling toleransi antara satu dengan yang lainya.

5. Jangan takut belajar dari orang lain, bila anda ingin kaya, pelajarilah mengapa orang jatuh miskin, bila anda ingin pintar pelajarilah kenapa orang bisa bodoh. Demikian juga bila anda mengalami kegagalan pelajarilah kenapa orang bisa sukses.

6. Bila anda sudah memegang teguh pola pikir yang kuat, ujilah pola pikir itu sehingga membuat hati anda damai dan semangat untuk menjalani hidup dengan segala kesulitanya. 
7. Teruslah belajar dan mendalami pola pikir yang sudah anda temukan. Teruslah belajar bila anda sudah menemukan pola pikir yang kuat. Usahakanlah untuk tidak merasa puas dengan apa yang telah anda capai.

Bagi-bagikanlah pola pikir yang telah anda terima bila anda mengalami ketangguhanya. Pola pikir yang hebat tidak layak disembunyikan dari public. Setiap orang berhak untuk mendengarkanya,Anda perlu bahkan harus menbagi-bagikanya kepada orang lain sekalipun anda tidak selalu bisa sempurna bertindak sesuai dengan pola pikir tersebut

\subsection{Pola Pikir Wirausaha}

Menurut McGrath dan MacMillan (2000), pada umumnya wirausaha memiliki lima karakteristik mindset, yakni:

1. Mereka sangat bersemangat dalam melihat atau mencari peluang baru dengan tetap selalu waspada, selalu mencari kesempatan untuk mendapatkan keuntungan dari perubahan dan hambatan dari kegiatan bisnis. Mereka akan memilih pengaruh yang amat besar ketika mereka menciptakan model bisnis yang baru dari cara memperoleh penghasilan, membuat pembiayaan, menjalankan operasional, dan keseluruhan kegiatan industri.

2. Mereka mengejar peluang dengan disiplin yang ketat. Umumnya wirausaha tidak hanya bersiap untuk peluang 
yang kecil, tetapi langsung mengambil tindakan terhadap peluang - peluang yang belum tergali. Mereka sering mengkaji ulang ide - ide mereka, tetapi mereka merealisasikannya hanya ketika hal itu diperlukan.

3. Mereka hanya mengejar peluang yang sangat baik dan menghindari mengejar peluang yang melelahkan diri dan organisasi mereka.

Walaupun kebanyak wirausaha adalah orang berbeda, untuk meraih kesuksesan besar tetap dituntut kedesiplinan dalam membatasi jumlah proyek yang hendak diraih.

4. Mereka menginkuti portofolio dari peluang dengan kendali yang amat ketat dalam berbagai tahap pengembangan.

5. Mereka focus pada pelaksanaan, khususnya yang bersifat adaptif. Orang dengan kerangka berpikir wirausaha akan memilih melaksanakan apa yang telah ditetapkan dari pada menganalisis ide baru yang menghancurkan. Adaptasi yang mereka lakukan adalah dengan mengubah arah kerja sesuai dengan peluang yang nyata dan mengambil langkah terbaik untuk merealisasikannya.

\subsection{Teori Kecerdasan Finansial}

Kunci kesuksesan transformasi dari perjuangan finansial hingga menuju pada kondisi kebebasan finansial sebagaimana konsep transformasi Cashflow Quadran-nya Kiyosakai adalah tergantung pada kecerdasan financial anda. 
Untuk mencapai kecerdasan financial ala Covey maupun kesuksesan financial ala Kiyosaki tersebut, kita harus berusaha mengubah "mindset" yang ada pada diri kita masing-masing mengikuti pola pikir "manusia sejahtera" yang efisien dan sesuai "konsep ekonomis". Kreativitas secara finansial dalam kenyataanya merupakan kesediaan untuk berpindah dari zona yang anda anggap nyaman sebelumnya menuju ke zona baru yang penuh tantangan. Seorang yang kreatif akan mampu melakukan perpindahan tersebut dengan perhitungan yang matang sehingga menghasilkan zona yang baru yang lebih nyaman pada masa depan dengan mengorbankan kenyamanan hari ini. 


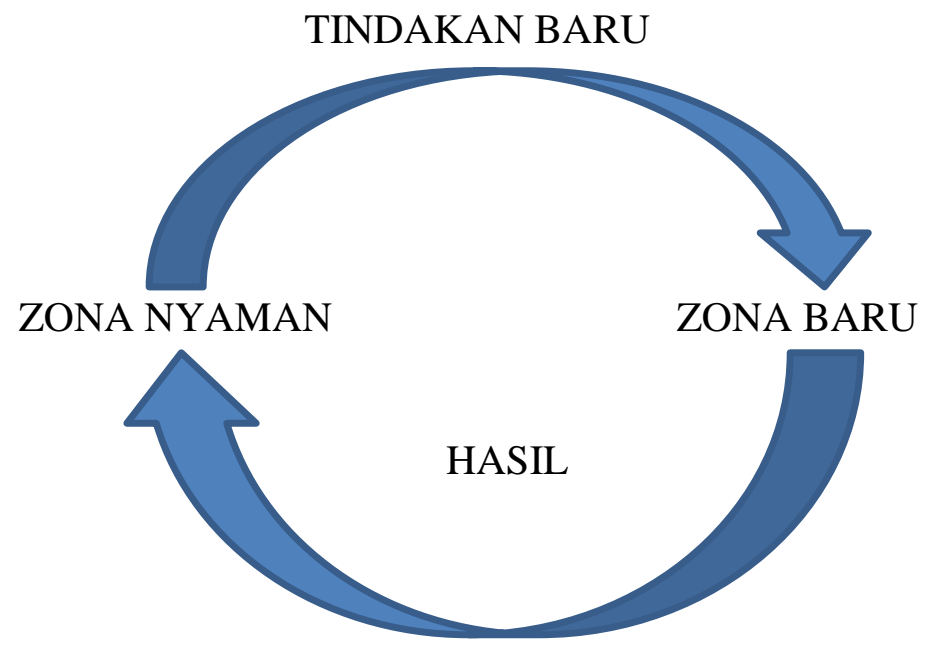

\section{TIPS PRAKTIS}

Setiap orang bertanggung jawab terhadap masa depannya sendiri. Masalahnya adalah apakah kita mau berubah?. Kalau setiap saat anda menyangkal realita baru atau berpikir negatif, itu artinya anda hidup dalam belenggu. Jelas anda memerlukan teknik-teknik mental baru uuntuk berubah sebelum memulai usaha. Syarat penting untuk meningkatkan motivasi berusaha adalah memahami konsep kecerdasan finansial.

Ada dua model konsep yang bagus untuk menanamkan pola pikir keuangan :

\section{MODEL KETERGANTUNGAN FINANSIAL DARI STEPHEN COVEY.}

Stephen Covey mendefinisikan kecerdasan finansial sebagai perbandingan antara "Total pendapatan" yang mampu anda hasilkan dibagi dengan "Total pengeluaran". 
Sejak bayi sampai remaja, skor kecerdasan finansial anda adalah nol. Semua kebutuhan anda selama masa-masa tersebut dipenuhi oleh orangtua. Anda belum mampu menghasilkan pendapatan. Anda berada pada tahapan ketergantungan (dependensi) kepaada orangtua sepenuhnya (100\%). Semakin dewasa, manusia semakin kreatif untuk memproleh penghasilan tambahan. Maka skor kecerdasan finansialnya pun meningkat. Peningkatan ini menunjukan ketergantungan finansial orang ini kepada orang lain (dalam hal ni orang tua) semakin berkurang.

Misalnya anda adalah seorang mahasiswa smester akhir pada sebuah universitas. Kebutuhan anda untuk membayar uang kos, makan, minum, SPP, buku, rekreasi sebulan adalah satu juta rupiah. Karena anda telah mampu mendapatkan penghasilan rata-rata sebesar lima ratus ribu perbulannya, maka skor kecerdasan finansial anda meningkat menjadi $5 / 10$, yaitu 0,5. Dengan kata lain ketergantungan finansial anda pada orang lain (dalam hal ini orang tua) sekarang berubah menjadi setengah dari semester sebelumnya. Semakin tinggi kemampuan anda untuk menghasilkan pendapatan, maka semakin tinggi pula skor kecerdasan finansial anda .bila anda telah mencapai skor $=1$, maka berarti ketegantungan anda pada orang lain adalah nol, dengan kata lain anda telah mampu memenuhi kebutuhan anda sendiri (independent). Semakin mampu anda berinvestasi secara cerdas, maka semakin tinggi skor kecerdasan anda. Ini berarti perjuangan finansial yang 
anda lakukan akan mampu mencapai tahapan keamanan dan kebebasan finansial.

\section{KONSEP WR(WEALTH RATIO) DAN CASHFLOW KUADRAN DARI ROBERT T.KIYOSAKI.}

Robert T.Kiyosaki, adalah seorang pengarang buku motivasi investasi. Ia mengelompkan kecendrungan seseorang dalam meraih penghasilan (kair finansial) kedalam 4 kuadran yang disebut "cashflow quadrant"

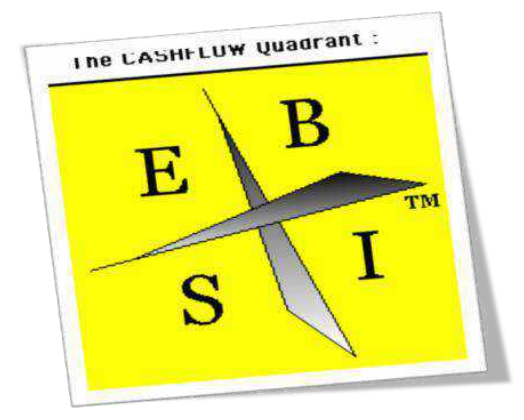

Kuadran tersebut dapat kita lihat sebagai berikut:

1. Kuadran E yaitu Employee (pekerja)

Pada kuadran E ini, pendapatan seseorang akan tergantung kepada majikannya. Ia hanya akan mampu "bekerja dengan setia" apabila dibayar dengan gaji yang tinggi. Dengan demikian, maka "nasib" dan "karirnya" pun juga akan tergantung pada "penilaian subyektif” sang majikan.

2. Kuadrant SE yaitu: Self Employee (Profesional)

Dimana pendapatannya akan tergantung seberapa keras ia bekerja. Semakin keras kerjanya, maka pendapatannya akan 
semakin banyak. Orang-orang dengan profesi dokter, pengacara, manajer perusahaan dan pengusaha bisnis pribadi sekala kecil adalah contoh mereka dari kuadran jenis SE ini.

\section{Kuadran B yaitu Business (bisnis)}

Dimana pendapatannya tidak tergantung pada kerja kerasnya secara langsung, tetapi dari "system bisnis" yang telah diciptakannya. Mereka yang berada pada kuadran ini tetap akan memperoleh penghasilan meskipun ia sedang berlibur jauh, karena system bisnisnya tidak mengharuskan mereka hadir secara fisik untuk menghasilkan uang. Sistem yang mereka ciptakan telah mampu membuat " orang lain bekerja untuk dirinya".

4. Kuadran I yaitu Investor

Pada posisi tertinggi ini mereka tidak perlu bekerja lagi, tetapi "uanglah yang bekerja untuk mereka". Para pemegang saham perusahaan Blue Chip dan tuan tanah property didaerahdaerah strategi adalah contoh dari para penghuni kuadran ini. Saham dan tanah yang mereka miliki setiap menitnya akan memberikan gain (keuntungan dari peningkatan nilai) secara konsisten. Inilah yang disebut passive income.

\section{Rangkuman}

1. Konsep wr (wealth ratio) dan cashflow kuadran dari robert

t.kiyosaki yaitu

a. Kuadran E yaitu Employee (pekerja) 

b. Kuadrant SE yaitu: Self Employee (Profesional)
c. Kuadran B yaitu Business (bisnis)
d. Kuadran I yaitu Investor

2. Stephen Covey mendefinisikan kecerdasan finansial sebagai perbandingan antara "Total pendapatan" yang mampu anda hasilkan dibagi dengan "Total pengeluaran

Pertanyaan Untuk Diskusi

1. Jelaskan Pentingnya Perubahan dan Peranan Mindset (pola pikir)

2. Jelaskan Konsep wr (wealth ratio) dan cashflow kuadran dari robert T. Kiyosaki

3. 3. Jelaskan model ketergantungan finansial dari stephen covey.

Tugas

Jelaskan dan berikan contoh pola pikir entrepreneur dengan pola pikir non entrepreneur 


\section{BAB IV \\ BERPIKIR KREATIF}

Tujuan Pembelajaran

Setelah mempelajari bab ini, calon wirausaha diharapkan :

1. Mengenal kreativitas sebagai modal penting wirausaha

2. Menjelaskan hambatan berpikir kreatif

3. Mengenalkan cara mengukur potensi kreatif

4. Teknik Meningkatkan Proses Kreativitas

5. Hak Kekayaaan Intelektual (HKI)

\subsection{Kreativitas Sebagai Modal Penting Wirausaha}

Bagi seorang wirausaha, kreativitas adalah modal yang sangat penting. Kreativitas merupakan kemampuan seseorang untuk dapat memikirkan dan mengembangkan ideide baru, cara-cara baru dalam melihat masalah peluang, sehingga muncul solusi kreatif. Sebagai wirausaha, sudah pasti akan mengahadapi persaingan yang kuat. Itu sebabnya wirausaha harus kreatif dan tidak mudah untuk mati akal. Tanpa adanya kreativitas, usaha anda hanya akan menjadi stagnant. Dengan kreativitas anda mampu berpikir keluar dari kotak, melihat dan menangkap peluang. Tanpa kekuatan kreativitas, wirausaha tidak akan pernah sukses dan bertahan, 
serta beradaptasi mengaruhi dunia yang akan sudah pasti berubah.

Dalam situasi ini, wirausaha dituntut bijaksana dalam menghadapi tekanan dan serangan. Kreativitas menjadi sangat penting karena :

1. Wirausaha yang kreatif dapat meluncurkan produk yang belum pernah dibuat dipasar. Anda bisa memecahkan masalah yang dihadapi masyarakat dengan memperkenalkan produk atau jasa baru yang terus menerus diperbaharui.

2. Dengan menjadi manusia kreatif, anda bukanlah peniru melainkan pemimpin. Pemimpin pasar disegani dan selalu jadi benchmark. Merek anda akan kuat dan melegenda. Anda bisa ditiru tapi peniru tidak bisa buat persis sama seperti yang anda lakukan.

3. First mover advantage. Dengan menjadi manusia kreatif. Anda akan memiliki keunggulan sebagai penggerak pertama, yang merintis akan menjadi pemimpin dan selalu siap dengan ide-ide baru.

4. Persaingan akan membuat jalan yang dilalui wirausaha akan menjadi semakin sempit dan banyak jalan yang semula terbuka lebar, akan ditutupi oleh pesaing-pesaing baru. Oleh karena itu, dibutuhkan kreativitas. Kreativitas juga berarti mencari cara atau jalan keluar baru,membuka terobosan-terobosan dan menciptakan perbedaan-perbedaan yang menonjol dan disukai pasar. 
5. Resiko adalah bagian dari kehidupan berwirausaha. Resiko merujuk pada aspek keuangan yang mematikan usaha,yang tidak bisa diatasi,bahkan dapat merusak reputasi dan kepercayaan terhadap diri anda.Hanya manusia yang kreatif yang dapat lolos dari bercana dan kerugian. Kreativitas membuat anda mampu menembus pintu-pintu baja kesulitan.

6. Kreativitas menghubungkan titik-titik terpisah dan terisolasi. Orang yang mampu menyatukan "mozaik" yang menjadi sebuah kode rahasia yang mengandung arti untuk membuka pintu rahasia kesulitan.

Kreativitas itu selalu beranjak dari sebuah ide yang muncul dari pengamatan terhadap keadaan sehari-hari disekeliling kita. Misalnya saja,pada awal tahun 1980-an, ada seorang mantan pegawai PT Pertamina yang melihat banyak orang asing yang tidak berani minum keran dari air keran yang disediakan di hotel-hotel Indonesia. Padahal di luar negeri, air keran di minum langsung. Mereka merasa bahwa air kita tidak higienis dan mengandung banyak bakteri mematikan. Setelah pensiun dari pertamina, orang itu, yaitu Tirto Oetomo, segera membangun usaha air yang layak diminum dalam kemasan. Sasaran awalnya adalah orang-orang asing yang berkunjung ke Indonesia yang pada akhirnya, air mineral dalam kemasan buatannya terkenal sebagai air minum dalam kemasan terbesar di indonesia,yaitu Aqua dengan kreativitasnya, Aqua berhasil 
menggantikan ceret-ceret yang biasa dipakai dirumah-rumah dan konsumen dapat langsung mengkonsumsinya tanpa harus memasak dahulu. Aqua sekarang telah tumbuh menjadi perusahaan besar dan ratusan merek sejenis beredar dipasar.Semua itu dimulai dari manusia kreatif yang melihat celah dipasar dan mau mengomersialisasikannya dan menanam resiko.

Disadari atau tidak, sejak lahir manusia sudah dibekali modal yang jauh jauh lebih penting dari sekedar uang yaitu, otak. Dengan modal tersebut,kita dapat berpikir, bertindak dan menyelesaikan masalah jauh lebih baik dari mesin atau mahkluk hidup lainnya. Dengan otak yang sehat, kita dapat berpikir kreatif sehingga timbul gagasan-gagasan dan terobosan-terobosan usaha yang inovatif. Banyak penelitian menunjukkan bahwa pada masa kanak-kanak kita jauh lebih kreatif dibandingkan saat dewasa. Saat berusia 5 tahun, kebanyakan dari kita mempunyai tingkat kreativitas sebesar 96,5\%. Pada saat itu kita bertanya lebih banyak 5 kali dibanding orang dewasa. Pada usia 17 tahun manusia mengalami penurunan tingkat kreativitas sehingga potensinya tinggal sekitar $86 \%$ dan pada saat berumur 30 tahun, secara rata-rata tingkat kretivitas kita tinggal $40 \%$. Penurunan tingkat kreativitas sejalan dengan semakin lanjutnya usia seseorang disebabkan oleh hubungan antara intensitas eksperimen dengan keinginan nencari aman. Semakin tua, langkah-langkah dan keinginan bereksperimen seseorang semakin menjadi rendah . 
Ini bereti semakin tua, manusia semakin cenderung menghindari resiko dan ingin menjalani hal yang aman-aman saja.

Banyak hal yang sebenarnya bisa dilakukan untuk melakukan kreativitas. Misalnya untuk barang -barang bekas yang biasanya dibuang atau menjadi limbah dapat dimanfaatkan untuk menjadi sesuatu yang berguna atau bernilai harganya, contohnya sebagai berikut:

\section{LAMPU HIAS DARI TEMPURUNG KELAPA}

Alat dan bahan yang diperlukan:

$>$ Limbah tempurung Kelapa

$>$ Lampu Neon kuning

$>$ Lem kayu

$>$ Papan $25 \mathrm{~cm} \times 15 \mathrm{~cm}$

$>$ Kayu bulat

$>$ Kabel

$>$ Stop kontak

$>$ Fiting lampu

$>$ Saklar lampu

$>$ Pernis

Peralatan yang digunakan:

$>$ Bor listrik/tangan : mata bor $10 \mathrm{~mm}$

$>$ Gergaji besi

$>$ Gerinda listrik/tangan

$>$ Kertas pasir halus dan kasar 
Langkah - langkah membuat Lampu hias

$>$ Sediakan 6 buah tempurung kelapa,

$>$ Kemudian 2 buah tempurung kelapa dipotong atasnya $3 / 4$ bagian. Sisa dari tempurung kelapa dibor membentuk lubang-lubang kecil.
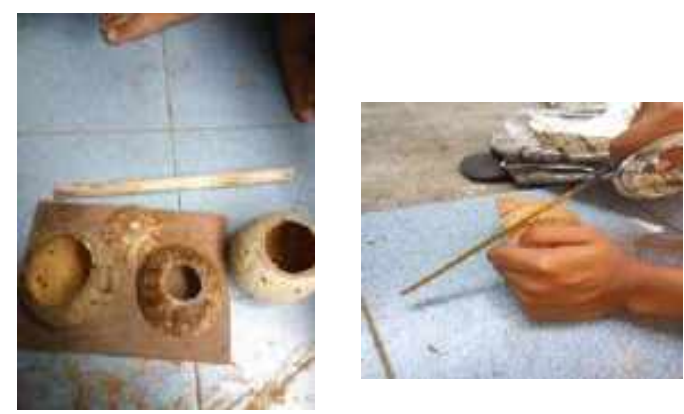

$>$ Lalu permukaan tempurung kelapa dihaluskan dengan menggunakan gerinda.

$>$ Sisa tempurung kelapa dibelah dan di ukir membentuk daun

$>$ Bagian dari sisa tempurung kelapa dijadikan alas dari lampu hias .

$>$ Direkatkan menggunakan lem.

$>$ Bagian dalam tempurung kelapa masukkan sarang lampu dan lampu
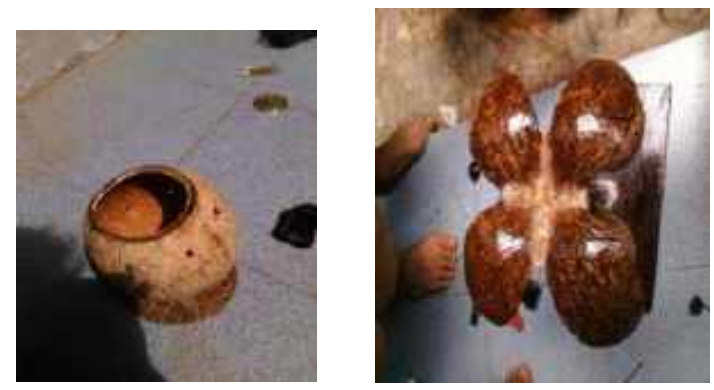
Sambungkan sarang lampu dengan kabel dan stop kontak.

> Lalu, memulai melakukan pernis terhadap bagian

Kayu dan tempurung kelapa.

$>$ Kemudian sepotong kayu ditempelkan dengan

Potongan tempurung kelapa yang telah dibentuk daun dengan lem. Dan diatasnya diberi serbuk kayu.

$>$ Lalu direkatkan kesebidang papan yang telah disiapkan tadi.

Hasil Akhir:

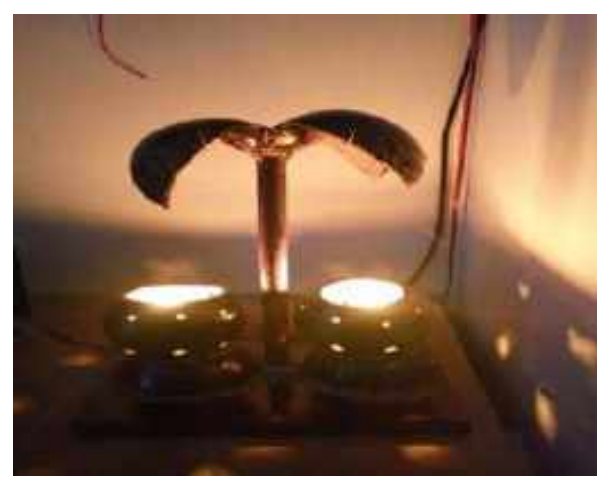

\subsection{Hambatan Berpikir Kreatif}

Sebagai manusia kita adalah ciptaan Tuhan yang paling unik. Perhatikanlah tidak ada dua orang manusia yang $100 \%$ sama, sekalipun mereka kembar. Dalam ilmu ekonomi, segala keunikan mempunyai nilai ekonomis yang dapat dibentuk menjadi sesuatu yang berharga sesuai dengan fitrah keunikan atau menghasilkan kesejahteraan. Dengan kata lain, bila anda punya bakat seni lukis yang tinggi, maka bentuklah diri anda 
menjadi pelukis yang andal, bukan menjadi dokter yang biasabiasa saja. Bila anda berbakat menjadi dokter,maka jadilah dokter yang terkenal dan janganlah menjadi pelukis yang biasabiasa karena bakat anda di bidang melukis kurang.

Kesalahan terbesar yang para sarjana dalam berkarier adalah ketidak tahuan dan keengganan dalam menggali dan memahami keunikan diri sendiri, serta ketidakmampuan dalam mengatasi hambatan berkreasi. Akibatnya,mereka memilih hidup yang biasa-biasa saja . Mereka terbelenggu oleh apa yang mereka dapatkan dengan sulit daripada mengenali potensi sendirinya. Banyak orang merasa tidak kreatif dan menyalahkan pekerjaannya tidak sesuai dengan bakatnya. Ada juga yang mengacaukan keadaan yang tidak mendukung untuk melakukan kreativitas.Atau selalu menyalahkan si bos yang tidak membri ruang gerak bagi dirinya. Apa pun alasannya, manusia yang tidak kreatif selalu melakukan hal yang sama berulang-ulang, cenderung menghindar resiko.I ngatlah, alasan hanya dibuat manusia untuk oranglain, bukan untuk memperbaiki dirinya sendiri

James L. A dams dalam bukunya conceptual blockbusting (1986) telah mengidentifikasi hambatan kreativitas tersebut dalam beberapa klasifikasi sebagai berikut. 


\begin{tabular}{|c|c|}
\hline Jenis Hambatan & Contoh \\
\hline Hambatan Persepsi & $\begin{array}{ll}\text { - } & \text { Pola Pikir stereotip } \\
\text { - } & \text { Membatasi masalah secara } \\
\text { berlebihan } \\
\text { - } & \text { Terlalu banyak atau terlalu } \\
& \text { sedikit informasi }\end{array}$ \\
\hline Hambatan Emosi & $\begin{array}{ll}\text { - } & \text { Takut mengambil resiko } \\
\text { - } & \text { Tidak menyukai } \\
& \text { ketidakpastian } \\
\text { - } & \text { Lebih suka menilai dari } \\
\text { - } & \text { Teda menghasilkan gagasan } \\
\text { - } & \text { menyelesa-gesa } \\
\end{array}$ \\
\hline Hambatan Kultural & $\begin{array}{ll} & \text { Kultur menghambat } \\
& \text { pengakumulasian gagasan }\end{array}$ \\
\hline Hambatan Lingkungan & $\begin{array}{ll} & \text { Kurangnya dukungan } \\
& \text { sarana, prasarana kerja }\end{array}$ \\
\hline Hambatan Intelektual & $\begin{array}{l}\text { - } \\
\text { Terlalu mangandalkan } \\
\text { logila } \\
\text { - } \\
\text { Enggan menggunakan } \\
\text { intuisa } \\
\text { - } \\
\text { Menggunakan pengalaman } \\
\text { atau cara lama yang } \\
\text { terbukti efektif hasilnya }\end{array}$ \\
\hline
\end{tabular}




\subsection{Mengukur Potensi Kreatif}

Melalui game ini, seluruh mahasiswa diajak untuk melihat sejauh mana kreatifnya mereka. Agar dapat menjadi wirausaha yang sukses dan dapat diandalkan menjadi alat penting. Melalui permainan kreativitas Planet Venus, mahasiswa diajak untuk wajib berpartisipasi dan kelas akan dibagi menjadi kelompok-kelompok dengan masing-masing kelompok terdiri dari 6-7 orang.Siapakah alat tulis dan dua lembar kertas polos ukuran folio atau a4.

"Bergembiralah karena anak didik sekalian terpilih menjadi astronot pertama yang akan menuju Planet Venus. Saudara adalah mahasiswa pilihan yang luar biasa. Maka layaklah kita menerawang luar angkasa, melihat jagat raya dan manyaksikan betapa agungnya ciptaan Tuhan. Planet ini letaknya sangat jauh dan membutuhkan perjalan kira-kira seminggu. Kita akan berangkat dan menggunakan pesawat ulang alik yang memiliki kecepatan yang pesawatnya belum pernah dilihat sebelumnya. Siapkan diri anda, dengan menyediakan kertas polos dua lembar,alat tulis,konsentrasi dan dengarkan baik-baik intruksi dari tenaga pengajar. Selamat bermain dan berkreativitas.

\subsection{Teknik Untuk Meningkatkan Proses Kreativitas}

Beberapa cara yang dapat dilakukan dalam meningkatkan kreativitas adalah:

a. Focus Group ( Kelompok Diskusi) 
Merupakan salah satu cara yang telah digunakan untuk meningkatkan proses kreatif sejak tahun 1950-an

b. Brainstorming (curah gagasan). Sekelompok kecil, biasanya terdiri dari 4-5 orang, distimulasi untuk mengeluarkan ide-idenya tanpa mengkritik ide yang dimunculkan oleh individu tersebut.

c. Mind mapping yaitu(pemetaan pemikiran) merupakan pengembangan brainstorming yakni dengan cara mengeluarkan ide - ide tidak secara sistematis dan linier.

d. Rapid prototyping (pembuatan protopipe singkat), metode untuk menguji dan menerapkan ide kreatif dan melakukan evaluasi secara tepat.

Contoh kreativitas sebagai berikut:

\section{Sejarah tentang Brownies Manten}

History of Brownies Manten :

Brownies Manten didirikan pada tanggal 18 September 2014 oleh dua orang yang saling berteman, yaitu Patria Prima Putra dan Awalinda Bestari. Meski terkadang perbedaan adalah sebuah alasan bagi kebanyakan orang untuk tidak membangun sesuatu bersama-sama, namun hal itu tidak berlaku bagi Patria Prima Putra dan Awalinda Bestari. Latar belakang yang berbeda satu sama lainlah yang membuat mereka semacam membutuhkan satu sama lain dan saling melengkapi kekurangan masing-masing. Awal mula Brownies Manten berdiri adalah karena faktor ketidaksengajaan, yaitu saat Patria 
dan Awalinda bertemu di suatu organisasi bisnis yang bernama ISC (Indonesia Sharing Club). Pada mulanya Patria dan Awalinda bertujuan ingin membeli atau mengakuisisi sebuat usaha brownies di Bali yang telah berjalan stabil dengan tujuan menjadi investasi dan sumber pemasukan pasti setiap bulannya. Namun ternyata apa yang mau dikata, mereka didahului oleh orang lain saat ingin mengakuisisi usaha brownies tersebut. Namun karena sudah memiliki tekad untuk memiliki sebuah usaha kuliner mereka pun sepakat membuat dari nol dari sebuah usaha kuliner.

Mulailah mereka menggelontorkan uang sebesar 3 juta Rupiah untuk membuat usaha kuliner Brownies Manten, yang diawali dengan memproduksi sendiri tanpa pegawai oleh Awalinda. Cerita pun Dimulai! Awalnya, ketika mereka hendak memilih nama, mereka sengaja membuat kata manten pada produk mereka, karena melihat tren bahwa anak muda sedang musimmusimnya membicarakan perihal nikah muda, dengan harapan nama tersebut membuat lebih mudah dikenal. Dan ketika mereka menamakan produk mereka dengan nama Brownies Manten, mungkin banyak yang bertanya. Mereka merubah hal tersebut menjadi kue yang digigit crispy dan lumer di mulut, sehingga banyak yang bertanya-tanya tentang hal itu. Akhirnya produk pun selesai, dan Awalinda menemukan resep di mana kue ini dibuat tanpa menggunakan bahan tepung serta mentega, sehingga sangat aman untuk mereka yang takut gemuk, karena segmentasi atau pasar mereka kebanyakan adalah wanita, dan 
ketika mereka mencari tahu apa yang wanita inginkan, mereka mendapati bahwa wanita itu mahluk yang hobi ngemil tapi takut gendut. Karena itulah Brownies Manten diciptakan rendah lemak dan kolestrol. Di bagian marketing Patria menciptakan sistem distribusi menarik yang sangat efektif. Dia menciptakan panggilan unik untuk setiap reseller dan distributornya. Dia menyebut distributor dengan nama "KUA", dan reseller dengan nama "Penghulu". Bukan tanpa alasan reseller disebut Penghulu. Karena mereka yang mempertemukan Brownies Manten dengan Calon Mantu (calon konsumen Brownies Manten), sehingga nama Penghulu-lah yang terpilih. Serta menyebut distributor sebagai KUA karena KUA adalah tempat berkumpulnya para Penghulu.

Mereka juga membuat kotak yang dapat ditulis dengan kata-kata romantis agar konsumen dapat menjadikan Brownies Manten sebagai sarana menyampaikan kasih sayang kepada kekasih dan keluarga yang mereka cintai, karena mereka melihat orang-orang di luar sana banyak yang saling mencintai, namun tak semuanya berani mengungkapkannya. Dan inilah tujuan Brownies Manten, yaitu dapat menjadi kado dan cara mengungkapkan kasih sayang kepada orang terkasih. Dengan segala keunikan tersebut, di luar dugaan Brownies Manten yang awalnya memiliki tagline "Oleh-Oleh dari Bali" ini diserbu pasar di seluruh Indonesia dalam waktu singkat. Bahkan mereka balik modal dalam waktu kurang dari 3 hari dan mendapatkan orderan lebih dari 2000 kotak di hari ketiga 
Brownies Manten berdiri, sehingga membuat antrian tunggu yang sangat panjang untuk orang yang penasaran ingin mencicipi Brownies Manten. Dalam waktu 3 hari itu juga-lah rekening usaha Brownies Manten mereka yang awalnya kosong, terisi dengan uang para pengorder yang berjumlah puluhan juta. Dengan uang itulah mereka membeli semua alat produksi serta merekrut karyawan. Mereka, Patria dan Awalinda beserta para karyawan, semakin hari semakin kelabakan karena perkembangan bisnisnya yang naiknya tidak wajar seperti bisnis pada umumnya. Di bulan pertama Brownies Manten berhasil terjual lebih dari 3000 kotak, dan di bulan kedua terus meningkat lebih dari 100 persen. Karena ketidakseimbangan antara marketing dan perkembangan produksi, mereka sempat kewalahan menerima orderan. Namun produksi mereka pun terus berkembang, sehingga pelan-pelan mereka dapat mengimbangi pasar. Dan dalam waktu 6 bulan pertama Brownies Manten telah mampu terjual sebanyak ratusan ribu kotak ke seluruh Indonesia dan Korea. Karena itu jugalah semakin banyak yang ingin meliput Brownies Manten, mulai dari media TV nasional hingga koran lokal yang mewawancarai setiap KUA di kota mereka masingmasing.

Dan sekarang mereka, dalam hal ini Patria dan Awalinda berserta para karyawan, terus berinovasi membuat Brownies Manten semakin gampang dimiliki oleh setiap Calon Mantu (calon konsumen). Mereka selalu berpikir untuk memberi 
kemudahan pada konsumen, sehingga terciptalah aplikasi ini, agar para konsumen dapat mendeteksi dan membeli secara otomatis Brownies Manten dari para Penghulu terdekat. Dengan ini pula-lah Brownies Manten menjadi snack pertama di dunia yang penyebarannya berbasis aplikasi, sehingga mempermudah konsumen menemukan atau mendeteksi Pengulu terdekat di kotanya. Semoga dengan aplikasi ini Brownies Manten dapat semakin lebih dekat dengan semua konsumen dari seluruh Indonesia.

https://sublibfood.wordpress.com/2017/06/08/sejarah -brownies-manten/ 


\subsection{Hak Kekayaaan Intelektual (HKI)}

Setelah seorang wirausaha menghasilkan ide kreatifnya da menerapkan ide-idenya, maka sebaiknya hasil karya tersebut dilindungi dalam bentuk hukum melalui kepemilikan HKI.

HKI atau hak atas kekayaan intelektual adalah hak yang timbul dari hasil olah pikir yang meghasilkan suatu produk atau proses yang berguna untuk manusia dan hak untuk menikmati secara ekonomis hasil dari suatu kreativitas intelektual.

Secara garis besar HKI dibagi menjadi 2 bagian yaitu:

1. Hak Cipta (Copy Right)

2. Hak Kekayaan Industri yang mencakup:
a. Paten
b. Desain Industri
c. Merek
d. Penanggulangan praktik persaingan curang
e. Desain tata letak sirkuit terpadu
f. Rahasia Dagang 


\section{Rangkuman}

1. Beberapa cara yang dapat dilakukan dalam meningkatkan kreativitas adalah

a. Focus Group ( Kelompok Diskusi)

b. Brainstorming (curah gagasan).

c. Mind mapping yaitu(pemetaan pemikiran) merupakan pengembangan

d. Rapid prototyping (pembuatan protopipe singkat).

2. Kreativitas merupakan kemampuan seseorang untuk dapat memikirkan dan mengembangkan ide-ide baru, cara-cara baru dalam melihat masalah dan peluang sehingga muncul solusi kreatif

Pertanyaan untuk diskusi

1. Mengapa kreativitas penting dalam kewirausahaan

2. Jelaskan langkah-langkah dalam meningkatkan kreativitas

3. Jelaskan pentingnya HKI bagi UMKM

Tugas:

Buatlah suatu kreativitas dalam bentuk produk dan bahan utama serta pendukungnya berasal dari barang bekas, kemudian langkah pengerjaannya di videokan dan dipresentasikan dalam bentuk power point 


\section{BAB V \\ BERORIENTASI PADA TINDAKAN}

Setelah mempelajari bab ini, calon wirausaha diharapkan:

1. Menjelaskan karakter yang berorientasi pada tindakan sebagai salah satu karakter yang terpenting bagi wirausaha

2. Menjelaskan sikap dan tindakan yang perlu dimiliki untuk dapat menjadi pribadi yang berorientasi pada tindakan.

\subsection{Karakter yang berorientasi pada tindakan}

Orientasi pada tindakan merupakan kemampuan berpikir dan bertindak cepat terhadap suatu keadaan maupun permasalahan dengan hasil solusi yang dianggap terbaik dan efektif bagi permasalahan tersebut. Karakter yang berorientasi pada tindakan adalah karakter-karakter yang dimiliki oleh pribadi yang cenderung memilih tindakan-tindakan nyata daripada hanya berkata-kata maupun berpikir.

Salah satu ciri seorang wirausaha adalah pikirannya yang lebih berorientasi pada tindakan (action) daripada sekedar bermimpi, berkata-kata, berpikir-pikir, atau berwacana. Seorang wirausaha selalu menghadapi resiko, ketidakpastian, dan keterbatasan dalam setiap masalah yang dihadapi. Jika hanya berkata-kata dan tak pernah bertindak, segala kesempatan yang ada berubah menjadi bencana (kerugian) 
Selain itu seorang wirausaha harus memiliki orientas PDCA -Plan, do check and action. Ini berarti dia tidak hanya sekedar menrencanakan berbagai strategi dan taktik, tetapi juga melaksanakanya. Secara spesifik, seorang wirasaha harus menghindari NATO (no action talk only), NADO ( no action dream only) dan NACO (No action concept only). NATO hanya akan menghasilkan gosip, NADO hanya menghasilkan visi tanpa tindakan, dan NACO hanya akan menghasilkan teori dan falsafah, Umumnya yang berpikiran NACO adalah akademisi yang berpikir menggunakan logika formal.

\subsection{Sikap dan tindakan bagi pribadi yang berorientasi pada tindakan}

Seorang yang berorientasi pada tindakan adalah orang yang memiliki tingkat efektivitas yang tinggi. Dalam materi ini, kita akan mempelajari karakteristik seseorang yang berorientasi pada tindakan. Dalam hal ini, akan digunakan konsep seseorang yang efektif yang dikemukakan oleh Stephen Covey (2004)

8 (delapan) habbits of highly effective people:

\section{Proaktif}

Seseorang yang efektif mengambil inisiatif untuk bertindak, bukan menunggu atau bewacana. Bertindak proaktif adalah mengambil tindakan sebelum sebuah kejadian yang tidak dikehendaki muncul Dengan kata 
lain, orang-orang yang proaktif selalu mengantisipasi hal-hal yang akan terjadi dan cepat mengambil tindakan penyelamatan. Mengapa mereka bisa bertindak cepat? Jawabannya adalah karena mereka sehari-hari berada dilapangan . Mereka melatih instuisi dengan menangkap segala signal tersebut. Sebagai contoh: menjelang lebaran, para pedagang tekstil sudah melakukan stok barang lebih banyak dari biasanya untuk mengantisipasi lonjakan permintaan. Dengan kata lain, ada "pola" yang dipelajari oleh seseorang wirausaha. Misalnya, pola permintaan pada hari-hari tertentu atau menjelang hari raya sehingga sebelum bulan puasa tiba, dia sudah melakukan penyetokan barang dalam jumlah yang cukup.

2. Bermula Dari Ujung Pemikiran (Goal Oriented)

Manusia yang berorientasi pada tindakan tidak hanya mengejar pencapaian tujuan, akan tetapi juga berburu tujuan yang benar. Supaya mampu berorientasi pada tindakan, manusia harus mengenal dan paham betul situasi yang dihadapi. Anda harus mengenal lingkungan (pasar) dimana Anda berada, produk yang Anda tangani pasar dan konsumennya harga, lokasi, siklus ekonomi, latar belakang suatu keadaan, dan seterusnya. Namun kenyataannya, semua itu tidak mudah. 
3. Mendahulukan hal yang utama

Kebiasaan ini berkaitan dengan sikap mengedepankan prioritas. Seseorang harus focus pada hal-hal yang urgent dengan membuat prioritas, dan menyadari bahwa tidak semua hal dikategorikan urgent. Demikian pula kita tidak bisa mengatasi semua masalah. Selesaikan masalah-masalah tertentu saja yang bisa diselesaikan, dan lainnya akan mengikuti. Sekali lagi, kita hanya bisa menyelesaikan sebagaian masalah saja, karena kita wajib memilihnya. Sebagai contoh tiap individu pasti mempunyai masing-masing dalam hidupnya.

\section{Berpikir dan Bertindak Win/win}

Bisnis atau berwirausaha pada dasarnya adalah upaya memenangkan kehidupan dan selalu bersikap win-win. Mereka berusaha agar semua pihak mencapai kondisi akhir yang baik. Pola berpikir win-win akan membantu kita menciptakan kerjasama.

5. Cari Tahu Dulu untuk memahami, baru dipahami. Agar dapat mengembangkan hubungan yang win-win, seseorang harus dapat mengetahui apa yang diinginkan oleh pihak lain dan apa makna menang bagi mereka. Dalam hal ini, kita harus dapat memahami apa yang menjadi kebutuhan dan keinginan orang lain sebelum mengutamakan tujuan pribadi kita. 


\section{Sinergi}

Dalam berwirausaha, Anda harus mencari sinergi, yaitu suatu total yang lebih besar dari penjumlahan elemenelemen tunggalnya. Misalnya, ada 2 phak A dan B, dan bila masing-masing bekerja sendiri-sendiri, masingmasing hanya akan menghasilkan 2 buah, dan kalau dijumlahkan $A+B=4$. Dengan sinergi antara $A$ dan B, maka $2+2>4$ inilah yang disebut sinergi. Sinergi yang efektif sangat bergantung pada komunikasi.

7. Menajamkan Ketahanan, Fleksibilitas dan kekuatan Habit ini berkaitan dengan upaya yang dilakukan oleh seseorang untuk melatih ketahanan, fleksibilitas dan kekuatannya. Upaya yang dapat dilakukan adalah melalui kegiatan-kegiatan spiritual, hidup yang seimbang, melakukan meditasi atau bisa juga dengan membaca buku-buku self help yang membangkitkan semangat atau mendengarkan musik.

Keseimbangan mental dapat mengubah kebiasaankebiasaan buruk, seperti kebiasaan menonton televisi berlebihan-atau bermalas-malasan. Dengan kata lain, hal ini berkaitan dengan latihan mengembangkan hati, koneksi emosi, dan keterikatan kita pada orang lain.

Selain itu , jangan pernah takut salah selama kesalahankesalahan tersebut masih kesalahan kecil.

8. Menemukan Keunikan Pribadi Dan Membantu Orang Lain Menemukannya. 
Menemukan keunikan berarti mengenal potensi yang dimilikinya, yang tersebar pada empat elemen utama, yaitu pkiran, tubuh, hati dan jiwa. Jika pikiran terus dikembangkan

\section{Rangkuman}

seorang wirausaha harus memiliki orientas PDCA -Plan, do check and action. Secara spesifik, seorang wirasaha harus menghindari NATO (no action talk only), NADO ( no action dream only) dan NACO (No action concept only).

\section{Pertanyaan Untuk Diskusi}

1. Jelaskan karakter yang berorientasi pada tindakan

2. Jelaskan sikap dan tindakan yang perlu dimiliki untuk dapat menjadi pribadi yang berorientasi pada tindakan.

\section{Tugas}

Sebutkan dan Jelaskan 8 (delapan) habbits of highly effective people 


\section{BAB VI \\ PENGAMBILAN RESIKO}

Setelah mempelajari bab ini, calon wirausaha diharapkan:

1. Menjelaskan konsep resiko

2. Menjelaskan bagaimana pengambilan resiko dilakukan

3. Mengindentifikasi resiko-resiko potensial yang terjadi ketika memulai usaha

4. Menjelaskan pengelolaan resiko

\subsection{Konsep Resiko}

Resiko dalam bahasa Inggris (Risk), yang bisa berarti kegagalan, Kendala, hambatan, akibatnya, bahayanya dan kerugiannya. Berhasil atau tidaknya suatu usaha atau bisnis pada dasarnya tidak tergantung pada besar kecilnya ukuran usaha atau bisnis, tapi lebih dipengaruhi dari bagaimana cara pengelolaannya antara lain dalam pengorganisasian, keuangan, pembukuan, pemasaran, produksi, bahan baku, model, desain produk dsb. Seorang wirausaha harus memiliki kemampuan menemukan dan mengevaluasi peluang usaha yang ada, mengumpulkan dan mendayagunakan sumber-sumber daya yang diperlukan untuk memperoleh keuntungan. Seiring dengan bertambah luasnya usaha maka akan bertambah rumit permasalahannya. Tapi pertumbuhan dan perkembangan 
usaha yang cepat, akan menanamkan rasa tidak takut untuk mengambil keputusan dan bersedia untuk menerima resiko. Jika dianalisa. Mengenai resiko suatu usaha atau bisnis, selalu berkaitan dengan kreativitas dan inovasi, serta merupakan bagian penting dalam mengubah ide ata gagasan para wirausaha.

Dalam dunia bisnis kita mengetahui beberapa defenisi resiko. Namun, secara umum selalu dikaitkan dengan adanya suatu ketidakpastian pada masa yang akan datang. Secara spesifik, risiko didefenisikan sebagai adanya konsekuensi, sebagai dampak adanya ketidakpastian yang memunculkan dampak yang merugikan pelaku usaha.

\subsection{Pengambilan Resiko}

Terdapat beberapa alasan mengapa seseorang mengambil resiko. Seseorang mengambil resiko bisa jadi didasari oleh keinginan untuk mendapatkan tingkat pengambalian/keuntungan yang sepadan dengan pengorbanan yang telah dia keluarkan. Ketika seorang melakukan kegiatan yang beresiko karena menginginkan keuntungan, biasanya dia mampu mengkalkulasi besarnya resiko. Atas dasar kalkulasi tersebut, dia akan menetapkan target keuntungan yang dikehendaki. 


\subsection{Mengindentifikasi Resiko Usaha}

Beberapa resiko yang sering dijumpai dalam bisnis, khususnya start-up business, yaitu:

1. Resiko murni adalah resiko yang muncul sebagai akibat dari sebuah situasi atau keputusan, yang konsekuensinya adalah kerugian. Beberapa bentuk resiko murni yang sering muncul diantara adalah:

a. Resiko hilang/rusaknya asset yang dimiliki yang diakibatkan kebakaran, pencurian, penggelapan, dan sebagainya

b. Kecelakaan kerja pada proses produksi

c. Risiko akibat tuntutan hukum pihak lain, misalnya keracunan dari makanan yang anda jual, tuntutan konsumen akibat kelalaian kita, dan sebagainya.

d. Risiko operasional lainnya

e. Bencana alam, seperti banjir, gempa, angin topan, dan sebagainya

2. Risiko Spekulatif

Risiko spekulatif adalah risiko yang muncul akibat situasi atau keputusan konsekuensinya bisa berupa keuntungan ataupun kerugian. Contoh risiko spekulatif diantaranya adalah:

a. Risiko perubahan harga

Harga pasar suatu produk, jasa atau komiditi dapat berubah-ubah. Ini dapat naik atau turun. Terkait dengan perubahan harga input jika harga input naik, 
maka perusahaan daopat mengalami kerugian penurunan margin keuntungan. Sebaliknya, jika harga input turun, maka perusahaan dapat mengalami keuntungan, yaitu berupa kenaikan marjin keuntungan.

b. Resiko kredit

Resiko kredit adalah resiko yang muncul dari transaksi kredit, seperti utang dagang. Jika pihak yang kita berikan kredit mengalami gagal bayar, maka kita akan mengalami kerugian.

\subsection{Pengelolaan Resiko}

Untuk melakukan pengelolaan resiko anda dapat menggunakan 4 pilihan strategi pengelolaan resiko, yaitu:

1. Dikontrol (risk control)

Yaitu upaya yang dilakukan agar probabilitas terjadinya resiko yang kita identifikasi menjadi berkurang. Mengontrol resiko juga dimaksudkan untuk mengurangi dampak yang mungkin terjadi.

2. Ditransfer kepada pihak lain (risk transfer)

Yaitu upaya-upaya yang secara sadar dilakukan dengan memindahkan resiko yang kita hadapi terhadap pihak lain. Hal ini dapat dilakukan dengan memindahkan resiko terjadinya kebakaran took kepada perusahaan asuransi. 
3. Dibiayai sendiri(risk retention)

Yaitu upaya - upaya mendanai dampak yang ditimbulkan oleh resiko. Dalam konteks mendanai resiko ini, terdapat dua cara, yaitu dengan menyiapkan dana cadangan (allowance) khusus untuk mendanai resiko, atau tanpa membuat cadangan.

4. Dihindari (risk avoidance)

Yaitu tindakan secara sadar untuk menghindari resiko yang dihadapi. Misalnya, jika selama satu minggu kedepan diprediksi hujan akan turun sangat lebat, maka jika Anda mempunyai bisnis restoran, anda disarankan untuk menghindari penjualan bermacam-macam minuman dingin/es. Hal ini dilakukan karena kemungkinan produk-produk itu tidak akan laku.

\section{Rangkuman}

1. Resiko dalam bahasa Inggris (Risk), yang bisa berarti kegagalan, Kendala, hambatan, akibatnya, bahayanya dan kerugiannya.

3. Untuk melakukan pengelolaan resiko anda dapat menggunakan 4 pilihan strategi pengelolaan resiko, yaitu:

a. Dikontrol (risk control)

b. Di Transfer kepada pihak lain

c. Dibiayai sendiri

d. Dihindari 
Pertanyan untuk diskusi

1. Jelaskan konsep resiko

2. Jelaskan bagaimana pengambilan resiko dilakukan

3. Jelaskan resiko-resiko potensial yang terjadi ketika memulai usaha

4. Jelaskan pengelolaan resiko

Tugas

Berikan contoh resiko yang dihadapi oleh wirausaha dan bagaimana cara penanggulangannya 


\section{BAB VII \\ KEPEMIMPINAN}

Tujuan Pembelajaran

Setelah mempelajari bab ini, calon wirausaha diharapkan:

1. Menjelaskan pentingnya kepemimpinan bagi wirausaha

2. Menjelaskan perbedaan manajer dan pimpinan

3. Menjelaskan teori kepemimpinan awal dan kontemporer

\subsection{Aspek kepemimpinan penting bagi wirausaha}

Wirausaha yang berhasil merupakan pimpinan yang berhasil, baik yang memimpin beberapa atau beratus-ratus karyawan. Dari hakikat pekerjaannya mereka adalah pemimpin, karena mereka harus mencari peluang-peluang, memulai proyek-proyek mengumpulkan sumber daya manusia dan finansial yang diperlukan untuk melaksanakan proyek, menentukan tujuan-tujuan untuk mereka sendiri dan orang lain, dan memimpin serta membimbing orang lain untuk mencapai tujuan. Karena seorang pemimpin yang efektif akan selalu mencari cara-cara yang lebih baik. Dan pemimpin yang kadar orientasi tugasnya rendah cenderung menjadi tidak aktif dalam dalam mengarahkan perilaku yang berorientasi pada tujuan, seperti perencanaan dan penjadwalan. Mereka cenderung bekerja seperti para karyawan lain dan tidak membedakan 
peranan mereka sebagai pemimpin organisasi secara jelas. Dari sifat hakikat kegiatan-kegiatannya, para wirausaha adalah pemimpin, pemimpin-pemimpin yang berorientasi orangnya efektif sangat terampil dalam memotivasi dan berkomunikasi dengan karyawan mereka. Dan seorang pemimpin harus mengetahui dan memahami kebutuhan-kebutuhan karyawan mereka dan gigih melibatkan karyawan mereka dalam mencapai sasaran-sasaran perusahaan.

\subsection{Perbedaan Antara Manjer Dan Pemimpin}

Pertama, dalam hal perencanaan manajer akan merencanakan sesuatu berdasarkan halhal yang sifatnya prosedural, teknis, terarah, tegas, dan tidak bertele-tele namun jika pemimpin tidak merencanakan sesuatu karena pemimpin tidak merancang rencana prosedural, pemimpin lebih memiliki visi atau pandangan dalam perencanaannya . Kedua, dalam hal pengaruh manajer memiliki pengaruh hanya dalam batasan formal, yang artinya dia akan memiliki pengaruh ketika dia secara formal diberikan jabatan seorang manajer kalau pemimpin memiliki pengaruh luas, kharismatik, dan energik dalam berpikir, bahkan ketika pemimpin itu sudah tidak jadi pemimpin lagi, pendapat-pendapatnya akan tetap di pertimbangkan dan di utamakan. Ketiga, dalam mengatur sumber daya manusia di organisasinya manajer akan memilih untuk memberikan perintah ini dan itu ketimbang menunggu anak buahnya melakukan sesuatu untuknya, misalnya manajer 
akan cenderung selalu memberikan tugas ini itu dan sebagainya, tugas itu biasanya terkesan menuntut jika pemimpin justru akan memberikan kekuatan wewenangnya untuk memberdayakan (empowering) anak buahnya, biasanya pemimpin akan menjelaskan bagaimana, apa, dan siapa yang harus merealisasikannya, namun justru anak buahnya akan dengan senang hati merealisasikannya untuknya. Keempat, dalam mengontrol organisasi dan anak buahnya, sang manajer akan cenderung malas untuk memberikan perhatian moral dalam mengontrol anak buahnya, namun justru lebih sering memberikan control yang sifatnya prosedural, seperti memberikan sanksi untuk memotivasi anak buahnya yang sudah menunjukkan gejala penurunan performa hal ini berbeda dengan sang pemimpin, karena pemimpin (leader) justru akan memberikan kepedulian kepada anak buahnya jika performa anak buahnya menurun. Kelima, dalam tujuan yang ingin dicapai manajer memiliki tujuan yang jelas dan memiliki target kuantitatif, yaitu mendapatkan hasil yang sudah digariskan perusahaan atau organisasi miliknya namun pemimpin akan lebih suka memperbaiki sistem di organisasinya yang ia rasakan kurang atau belum sempurna. 


\subsection{Kepemimpinan Awal Dan Kepemimpinan}

\section{Kontemporer}

\section{Definisi kepemimpinan}

Kepemimpinan bukanlah pengajaran melainkan suatu hasil. Kata pemimpin bukan lebel yang kita berikan kepada diri sendiri. Pemimpin adalah apa yang orangorang yang telah kita inspirasikan sebutkan untuk kita karena mereka didorong berpartisipatif dalam visi positif yang kita sajikan kepada mereka. Maka kepemimpinan adalah :

a. Kepemimpinan adalah kemampuan seseorang untuk mempengaruhi orang lain sehingga orang lain tersebut bertingkah laku sebagaimana yang dikehendaki oleh pemimpinnya. Dalam hal ini bukan pengendalian atau manipulasi atas orang lain melainkan penyerahan otoritas orang lain dengan rela kepada pemimpin mereka.

b. Kepemimpinan adalah kapasitas untuk mempengaruhi orang lain melalui inspirasi yang dimotivasi oleh suatu hasrat, dibangkitkan oleh suatu visi, dihasilkan oleh suatu keyakinan, dinyalakan oleh suatu tujuan.

\section{Definisi Kontemporer}

Definisi kata kontemporer menurut kamus besar bahasa Indonesia adalah pada waktu yang sama; semasa; sewaktu; pada masa kini; dewasa ini Contoh : Di samping tarian 
klasik disuguhkan juga tarian modern. Bulan ini diadakan pameran seni lukis di Taman Ismail Marzuki, Jakarta Definisi kepemimpinan kontemporer dari pengertian awal atau dasar di atas maka definisi sederhana dari kepemimpinan kontemporer dapat kita simpulkan kepemimpinan

\section{Rangkuman}

Kepemimpinan bukanlah pengajaran melainkan suatu hasil. Kata pemimpin bukan lebel yang kita berikan kepada diri sendiri. Pemimpin adalah apa yang orang-orang yang telah kita inspirasikan sebutkan untuk kita karena mereka didorong berpartisipatif dalam visi positif yang kita sajikan kepada mereka.

Pertanyaan untuk Diskusi

1. Jelaskan pentingnya kepemimpinan bagi wirausaha

2. Jelaskan perbedaan manajer dan pimpinan

Tugas

Jelaskan Teori Kepemimpinan Awal dan Kontemporer 


\section{BAB VIII \\ ETIKA BISNIS}

Tujuan Pembelajaran

Setelah mempelajari bab ini, calon wirausaha diharapkan :

1. Menjelaskan peranan etika dalam bisnis

2. Menjelaskan rahasia sukses jangka panjang

\subsection{Peranan Etika dalam Bisnis}

Etika bisnis adalah segmen etika terapan yang mencoba untuk mengontrol dan memeriksa pengaturan moral dan etika perusahaan. Ia juga mendalami seberapa baik atau buruk badan usaha membahas masalah-masalah moral dan etika dan menunjukkan apa yang salah dalam proses alami mereka. Ini mencakup semua aspek bisnis dari produksi untuk administrasi, keuangan dan pemasaran. Hal ini juga berlaku untuk berbagai industri dan dapat deskriptif atau normative dalam disiplin. Penerapan etika bisnis dalam kewirausahaan mencerminkan keterlibatan perusahaan non nilai-nilai sosial ekonomi didorong-yang saat ini, telah sangat diabaikan. Itu membuat perusahaan sejalan dengan lebih baik dan membuat mereka pemain kontributif untuk praktek bisnis sehat. Seperti kita semua tahu, prospek penghasilan lebih mungkin melebih-lebihkan keinginan kebanyakan pengusaha untuk terlibat dalam penebangan, transaksi tidak etis. Hal ini memaksa mereka 
untuk menipu, berbohong, mencuri dan menyangkal orang lain hak-hak mereka untuk double/triple pendapatan atau maju. Misalnya, kurangnya pengaruh etika dapat menyebabkan perusahaan-perusahaan farmasi untuk dokter laporan laboratorium mengenai efek samping obat yang paling laku. Hal ini dapat mendukung bias gender dalam perekrutan. Dan juga dapat menyebabkan perusahaanperusahaan kaya untuk menahan manfaat dan upah dari pekerja mereka. Meskipun jelas tidak pantas, ini adalah masalah sosial dan bisnis yang masih saat ini lazim planning bisnis - dengan demikian menekankan penerapan bijaksana etika dalam bisnis.

Seperti digambarkan dalam film The Insider yang dibintangi Russel Crowe dan Al Pacino, ada konsekuensi yang signifikan terhadap kurangnya etika dalam prosedur bisnis. Untuk menjelaskan, kebejatan etis telah menghasut menyabot banyak perusahaan, serikat pekerja, dan tuntutan hukum. Dalam ekstrim, telah menyebabkan penutupan dan penurunan komersial. Ini telah tumbang pemimpin dan pemerintah dan ribuan nyawa dikompromikan. Jika ada, perusahaan harus memperlakukan etika sebagai bagian penting dari operasi sehari-hari mereka. Mengingat tujuan di balik keberadaan mereka, peran mereka bermain dalam masyarakat dan kontribusi mereka ke seluruh dunia, perusahaan yang terikat secara hukum bertanggung jawab atas kesejahteraan konsumen mereka melalui etika. Ini adalah hal yang baik 
bahwa banyak pengusaha pemula sekarang lebih dikenal etika bisnis untuk kewirausahaan. Ini menghemat masa depan dari menjadi korban dari pengaruh masa lalu komunitas bisnis sejahtera. Jika ada, kita tidak ingin mengulang kesalahan kita. Etika bisnis saat ini diajarkan di banyak lembaga dan ada juga ribuan referensi dibuat tersedia secara online. Dengan demikian, setiap pengusaha calon diberi kewenangan untuk menerapkannya. Kita semua harus ingat bahwa sebagai pengusaha, itu merupakan bagian dari tanggung jawab kita untuk menjalankan bisnis kami di bawah kode moral yang menghormati, mencari keadilan dan mempromosikan kebaikan semua orang.

\subsection{Rahasia Sukses Jangka Panjang}

Dalam berwirausaha, apapun juga bisnis yang Anda tekuni, ingatlah bahwa usaha yang lenggeng adalah usaha yang dijunjung oleh nilai-nilai etika. Berbagai studi menemukan perusahaan-perusahaan yang tumbuh menjadi besar bukanlah perusahaan yang diawali oleh manajer-manajer hebat yang digaji mahal, atau dibangun oleh pendiri yang luar biasa. Demikian juga bukan moda kuat atau kecerdasan para pendirinya. Perusahaan yang tumbuh menjadi besar justru dimulai dari orang-orang biasa yang sedari awal memegang teguh nilai-nilai moral dan etika. Mereka menjaga kepercayaan dan tidak sembarangan dalam berkata-kata, apalagi dalam bertindak. 


\section{Rangkuman}

Etika bisnis adalah segmen etika terapan yang mencoba untuk mengontrol dan memeriksa pengaturan moral dan etika perusahaan. Ia juga mendalami seberapa baik atau buruk badan usaha membahas masalah-masalah moral dan etika dan menunjukkan apa yang salah dalam proses alami mereka. Ini mencakup semua aspek bisnis - dari produksi untuk administrasi, keuangan dan pemasaran

Pertanyaan Untuk Diskusi

1. Jelaskan peranan etika dalam bisnis

2. Jelaskan rahasia sukses jangka panjang

Tugas

Jelaskan dan Berikan contoh penerapan etika bisnis di dunia usaha 


\section{BAB IX \\ FAKTOR X}

Tujuan pembelajaran

Setelah mempelajari bab ini, calon wirausaha diharapkan:

1. Menjelaskan pengertian faktor $X$

2. Menemukan dan menggali faktor $X$

3. Menjelaskan sikap-sikap menghadapi faktor $X$

4. Menjelaskan tipe-tipe dan karakteristik faktor $\mathrm{X}$

\subsection{Pengertian Faktor X}

Faktor X merupakan faktor yang melekat pada diri semua orang, tak berwujud benda namun dapat dirasakan. Pada diri seorang entreprenuer faktor $\mathrm{X}$ sangat mempengaruhi geraknya dalam menjalankan usaha.

\subsection{Menggali Faktor X}

Ada $\mathrm{X}$ besar dan ada pula $\mathrm{X}$ kecil, $\mathrm{X}$ besar ada ditanga $\mathrm{n}$ orang dewasa yaitu orang-orang yang sudah memiliki kepercayaan pasar. Sedangkan X kecil ada pada diri orang masing-masing. Bentuk X pun macam-macam, dapat berasal dari diri sendiri, orang lain, atau lembaga lain. Darimanapun sumbernya faktor $\mathrm{X}$ itu dapat tumbuh menjadi $\mathrm{X}$ besar atau bahkan sebaliknya. Faktor $\mathrm{X}$ yang berasal dari diri sendiri adalah bakat (talenta), kerja keras, kejujuran, kecerdasan, keterampilan, penampilan fisik, kualitas suara, dan pendidikan. 
Kita dapat menunggang kuda yang berasal dari atau orang lain atau lembaga lain untuk menemukan pintu. Temuilah orangorang yang dapat membuat anda menemukan faktor $\mathrm{X}$ dalam diri Anda, jadikan mereka guru dan motivator Anda. Berikut tips yang dapat Anda lakukan dalam menggali faktor X dalam diri Anda:

\section{Kenalilah diri Anda sendiri dan mulailah menimbulkan $\mathrm{X}$ pada diri Anda.}

a. Carilah pintu yang mampu membuat X Anda tumbuh. Datangi dan ketuklah masing-masing pintu itu. Pintu yang bagus adalah pintu yang didalamnya terdapat ruang besar bagi Anda untuk berkembang dan di dalamnya terdapat pintu-pintu lain yang tentunya dapat Anda buka.

b. Waspadailah hidup yang nyaman karena hidup yang demikian dapat membuat hidup Anda sulit. Berselancarlah pada gelombang-gelombang ketidaknyamanan dengan berani menembus segala halhal baru yang sulit karena Anda akan mendapatkan pembelajaran-pembelajaran baru.

c. Pintu yang tepat adalah pintu yang membuat Anda merasa mampu untuk tumbuh dan memberi ruang untuk berkembang. 


\subsection{Sikap Menghadapi Faktor $X$}

Sikap itu adalah sebuah pilihan.Pilihannya bermacam-macam:

a. Ada yang mendiamkan saja. Ia adalah orang yang percaya diri dengan bakatnya dan membiarkan "pintu"menemukan dirinya. Kalau ia beruntung bisa saja ia berhasil.Namun faktanya, sedikit sekali orang yang berhasil yang menggunakan cara ini.

b. Mengirim sinyal positif. Orang kedua ini sepertinya diam dan menunggu pintu mendatanginya,namun sesungguhnya ia tidak diam.ia mengirimkan signal agar "pintu"itu bergerak menghampirinya.Dengan kata lain,ia mengetuk "pintu"itu dengan bahasa tubuhnya. Apakah itu penampilannya yang menarik, suaranya yang khas,dan sebagainya.Mencari pintu,mengetuk pintu. Orang yang ketiga ini adalah orang yang kurang beruntung.Mereka sadar bahwa "pintu”tidak akan terbuka kecuali mereka mendatangi dan mengetukngetuknya,maka mereka mendatangi sebuah pintu.Pintu itu mungkin Cuma dibuka separuh oleh pemilik atau penghuninya.Ia tidak welcome.Anda harus pergi mencari pintu lainnya.Terus mencari dan mengetuknya.Namun begitu berada di dalam pintu itu,lagi-lagi sikap mereka berbeda-beda

c. Ada yang sudah merasa nyaman dengan berada di ruang tunggu yang membukakan pintu itu.Ia tidak mengerti bahwa ia hanya welcome di ruang itu 
saja.Ruang itu terlalu kecil,namun ia sudah merasa betah.

d. Ada yang segera menyadari bahwa ruang itu sekedar ruang tunggu saja.Kalau pintu utama tidak dibukakan ia segera keluar mencari pintu lainnya yang lebih welcome dan di dalamnya tersimpan pintu-pintu lain yang boleh ia ketuk dan masuk ke dalamnya.

Demikianlah, hidup adalah sebuah pikiran.Ada demikian banyak pilihan yang tersedia. Masalahnya, apakah kita mau mendatangi pilihan-pilihan itu, mengetuknya,dan mengambil pilihan yang terbaik? Dalam berwirausaha, seorang pemula dapat diibaratkan sebagai seseorang yang mencari pintu. Sukses yang dicapainya adalah sebuah keberhasilan menemukan pintu yang sesuai dengan minat dan masa depannya.Tapi untuk menemukan "pintu"itu ia harus mandapatkan jawaban yang setimpal.

\subsection{Tipe Dan Karakteristik Faktor X}

\section{Tipe Faktor $\mathbf{X}$}

"X"Kecil dan "X" Besar Dengan demikian faktor " $x$ " tidak lain adalah sesuatu yang kita cari dan kita miliki.Ia akan menemani siapa saja yang ingin berubah,menjadi lebih baik. Orang yang tidak ingin berubah juga memiliki faktor "x",namun itu hanyalah "x"kecil yang berarti sebuah kenyamanan. Ia sudah nyaman dengan kondisi sekarang dan tentu saja 
hidupnya tidak akan mengalami kemajuan. Untuk mengalami kemajuan, seseorang harus berani berselancar pada gelombang ketidaknyamanan. Entrepreuner adalah orang yang merasa hidupnya kurang nyaman, terancam, miskin atau kurang bermakna. Maka berjuang mengejar kenyamanan baru. Ia bergerak, berjalan ,berpikir , mengetuk pintu, mengambil resiko, mencari produk, membuat, membangun usaha, mendatangi pelanggan, dan seterusnya. Kalau ia diam atau menikmati warisan orang tua,ia sudah bisa hidup nyaman. Tapi dia ingin masa depannya lebih baik. Dari pada hidup susah nanti, lebih baik sulit sekarang. Ia tidak memilih hidup nyaman dengan " $\mathrm{x}$ " kecil warisan,melainkan membentuk " $x$ "besar. Lambat laun " $x$ " yang dikejar akan membesar dan melakat pada diri Anda, dan seperti benih tanaman, ia dapat tumbuh menjadi keahlian,kepercayaan,magnet,dan tentu saja rejeki. Karena melekat,ia tidak dapat dirampas dari diri Anda. Faktot " $x$ " yang melekat pada diri Anda.Faktor " $x$ " yang melekat pada diri Anda itu adalah benda tak berwujud, namun dapat dirasakan. Awalnya ia tidak melekat pada diri Anda,atau kecil sekali. Namun kalau Anda tekun ia akan terus tumbuh karena ia hidup. Dan karena ia hidup, ia pun dapat menjadi mati.Ia akan hidup kalau Anda menjaga kepercayaan, menumbuhkan 
kreatifitas dan keahlian, dan memberi banyak oksigen dari lingkungan yang bersih. Ia akan mati kalau Anda main-main dengan kepercayaan, berperilaku arogan, menentang pembaharuan, dan membiarkan terjadi penuaan.

\section{Karakteristik faktor " $x$ "}

- Merupakan penetuan keberhasilan

- Merekat pada diri manusia.

- Tidak diperoleh dalam waktu sekejab.

- Namun ia dapat tumbuh dan berkembang menjadi " $\mathrm{x}$ " besar.

- Berasal dari diri sendiri,namun juga dapat berasal dari luar diri.

- Sekali tumbuh ia dapat dipakai untuk usaha lainnya.

\section{Rangkuman}

1. Faktor $X$ merupakan faktor yang melekat pada diri semua orang, tak berwujud benda namun dapat dirasakan. Pada diri seorang entreprenuer faktor $\mathrm{X}$ sangat mempengaruhi geraknya dalam menjalankan usaha.

2. Karakteristik faktor " $\mathrm{x}$ "

- Merupakan penetuan keberhasilan

- Merekat pada diri manusia.

- Tidak diperoleh dalam waktu sekejab.

- Namun ia dapat tumbuh dan berkembang menjadi " $x$ " besar. 


\section{Pertanyaan Untuk Diskusi}

1. Jelaskan pengertian faktor $\mathrm{X}$

2. Bagaimana cara menemukan dan menggali faktor $X$

3. Jelaskan sikap-sikap menghadapi faktor $\mathrm{X}$

4. Jelaskan tipe-tipe dan karakteristik faktor $\mathrm{X}$ 


\section{BAB X \\ MENCARI GAGASAN UTAMA}

Tujuan Pembelajaran

Setelah mempelajari bab ini, calon wirausaha diharapkan

1. Menjelaskan Cara-Cara Mencari Gagasan Usaha

2. Menjelaskan bidang usaha: Kreatif, Konsultatif, Pelayanan

Dan Analitis

3. Menjelaskan Ide Usaha Dari Imitasi

Gagasan atau ide merupakan hal yang kadang dirasa sangat sulit untuk ditemukan dan terkadang gagasan yang berhasil ditemukan tidak sesuai dengan tujuan utama yang ingin dituju atau dicapai. Akan lebih sulit lagi jika gagasan tersebut diperoleh dari pemikiran bersama. Diperlukan pemikiran yang lebih matang untuk memilih atau menggabungkan gagasan yang dicetuskan setiap individu agar nantinya diperoleh suatu gagasan yang bisa digunakan untuk mencapai kepentingan bersama. Dalam modul ini mahasiswa akan belajar mengenai mencari gagasan sebagai salah satu tolak ukur keberhasilan dari kegiatan berwirausaha. Substansi materi terdiri dari pengertian gagasan, metode ATM, bidang usaha berbagai kelompok serta hubungan kreativitas, ide dan peluang. 


\subsection{Cara-Cara Mencari Gagasan Usaha}

Gagasan atau ide merupakan istilah yang dipakai baik secara populer maupun dalam bidang filsafat dengan pengertian umum "citra mental” dan "pengertian". Gagasan menyebabkan timbulnya konsep yang merupakan dasar bagi segala macam pengetahuan, baik sains maupun filsafat. Sekarang ini banyak orang percaya bahwa gagasan adalah suatu kekayaan intelektual seperti hak cipta atau paten. Di dalam Kamus Besar bahasa indonesia ide diartikan sebagai rancangan yang tersusun di pikiran. Artinya sama dengan gagasan atau cita- cita. Selama ide belum dituangkan menjadi suatu konsep dengan tulisan maupun gambar yang nyata, maka ide masih berada di dalam pikiran. ide yang sudah dinyatakan menjadi suatu perbuatan adalah karya cipta. Untuk mengubah ide menjadi karya cipta dilakukan serangkaian proses berpikir yang logis dan seringkali realisasinya memerlukan usaha yang terus menerus sehingga antara ide awal yang muncul dipikiran dan karya cipta satu sama lain saling bersesuaian sebagai kenyataan. Jika sudah ada ide, hal pertama yang harus dilakukan adalah bergerak, kaena tanpa itu, ide hanyalah menjadi sebuah pemikiran saja

\subsection{Kreatif, Konsultatif, Pelayanan Dan Analitis}

Dengan karakter, bakat, keterampilan atau hobi yang dimiliki. Di sini, blidang usaha dibagi menjadi 4 bidang usaha yang dikategorikan berdasar karakter, bakat, keterampilan dan 
hobi, yaitu bidang usaha kelompok kreatif, konsultatif, pelayanan dan analitis.

1. Kelompok Kreatif:

Terdiri dari orang orang yang karena kreativitasnya, sangat mendambakan kebebasan. Dalam bekerja, mereka berorientasi pada pencapaian hasil akhir yang baik. Biasa bekerja sendiri, tidak banyak bicara jadi mereka tergolong pada orang orang yang "tidak pintar ngomong". Karena sifatnya dominan, dalam berwiraswasta seyogyanya lebih memilih bidang-bidang yang tidak perlu banyak berhubungan dengan orang lain guna "lobi-melobi” karena tugas itu tidak cocok dengan temperamennya. Mereka juga termasuk introvert.

Oleh sebab itu, lebih baik bergerak dalam bidang produksi, antara lain:

a. Bidang makanan dan minuman

b. Kerajinan

c. Logam

d. Pertanian dan Agrobisnis

e. Peternakan dan hasil-hasil tambak

f. Rajutan, border, dan renda

g. Sabion

h. Penerbitan

i. Mainan Anak-anak

j. Kartu Ucapan

k. Karya-karya Intelektual 


\section{a. Bidang Usaha Kelompok Konsultif}

Orang-orang dari kelompok ini bersifat dominative dan karena berpembawaan extrovert mereka menyukai pergaulan, senang bertemu dengan publik dan pandai bicara. Meski demikian, mereka selalu cenderung mempengaruhi orang lain. Senang popularitas. Positifnya, kebanyakan dari mereka suka membantu dan menolong. Oleh karena itu, orang-orang konsultatif lebih sesuai dalam bidang-bidang usaha yang bersifat mengarahkan atau member intruksi, antara lain:
a. Jasa Konsultasi
b. Kursus-kursus
c. Pusat Kebugaran dan Pelatihan Olahraga
d. Bidang Perdagangan

\section{b. Kelompok Pelayanan}

Kelompok ini termasuk "extrovert", tetapi kepribadiannya berbeda dengan kelompok konsultatif. Kalau yang disebut terakhir lebih condong mendominasi, maka kelompok servis cenderung melayani atau mengikuti keinginankeinginan orang lain. Oleh sebab itu bidang-bidang yang sesuai dengan mereka antara lain:

1. Biro jasa

2. Biro teknik

3. Jasa Pengetikan 
4. Fotokopi dan Penjilidan

5. Sablon Pesanan

6. Perbengkelan

7. Kontraktor dan Jasa Perbaikan Bangunan

8. Rumah kos

9. Salon kecantikan

10. Makelar

\section{c. Kelompok Analitis}

Sifat introvert terkombinasi dengan pembawaan yang dedikatif membuat kelompok ini lebih sesuai dengan pekerjaan-pekerjaan yang bersifat "memecahkan problem" (problem solver). Kelompok analitis sebenarnya kurang suka bertemu dengan banyak orang, apalagi jika frekuensinya sangat sering. Bidang-bidang usahai tu semacam itu antara lain adalah:

1. Jasa Penerjemah

2. Jasa Reparasi Perangkat Elektronik dan Teknologi Informasi

3. Karya intelektual

4. Perancang Busana

5. Laundry

6. Jasa Penjahitan 


\subsection{Usaha dari Imitasi}

Ide usaha muncul karena adanya informasi yang sudah ada, lalu mencari kelemahan-kelemahan dan kekurangannya dan memperbaikinya. Namun, selalu gunakan brand sendiri. Selanjutnya, ide-ide usaha muncul karena adanya informasi yang mengindikasikan adanya kebutuhan,. Pendekatan ini membutuhkan data dan pertimbangan-pertimbangan. Kebutuhan tersebut mungkin sekarang belum dapat terpenuhi karena produk yang tersedia masing sangat mahal atau hal-hal yang belum terpenuhi. Oleh karena itu, kita perlu melakukan hal-hal seperti dibawah ini:

a. Mempelajari industri yang sudah ada

b. Mengkaji input dan output industri

c. Menganalisis tren populasi dan data demografi

d. Mengkaji Tren Ekonomi

e. Analisis terhadap perubahan social

f. Mengkaji pengaruh aturan baru

Rangkuman

1. Gagasan atau ide merupakan hal yang kadang dirasa sangat sulit untuk ditemukan dan terkadang gagasan yang berhasil ditemukan tidak sesuai dengan tujuan utama yang ingin dituju atau dicapai.

2. Gagasan atau ide merupakan istilah yang dipakai baik secara populer maupun dalam bidang filsafat dengan pengertian umum "citra mental" dan "pengertian". Gagasan 
menyebabkan timbulnya konsep yang merupakan dasar bagi segala macam pengetahuan, baik sains maupun filsafat

\section{Pertanyaan Untuk Diskusi}

1. Jelaskan cara-cara mencari gagasan usaha

2. Jelaskan bidang usaha: Kreatif, konsultatif, pelayanan dan analitis

3. Jelaskan ide usaha dari imitasi 


\section{BAB XI \\ PEMASARAN}

Tujuan Pembelajaran

Setelah mengikuti bab ini, calon wirausaha diharapkan bahwa:

1. Menjelaskan konsep pemasaran

2. Menjelaskan strategi dan taktik pemasaran

3. Menjelaskan konsep bauran pemasaran

Kotler (2003) mengatakan bahwa pemasaran sebagai suatu proses sosial dan manajerial dimana individu dan kelompok mendapatkan apa yang mereka butuhkan dan inginkan dengan menciptakan, menawarkan dan mempertukarkan produk yang bernilai dalam pasar. Pemasaran melibatkan banyak kegiatan yang berbeda yang menambah pada saat produk bergerak melalui sistem tersebut.

Pemasaran memiliki inti yang meliputi kebutuhan (needs), keinginan (wants), dan permintaan (demands). Kegiatankegiatan dalam usaha pemasaran tidak hanya kegiatan memindahkan barang/jasa dari tangan produsen ke tangan konsumen saja dengan sistem penjualan, tetapi banyak kegiatan lain yang juga dijalankan dalam kegiatan pemasaran. 


\subsection{Konsep Pemasaran}

Sebuah industri mempraktik konsep pemasaran tertentu untuk mencapai objektif pemasarannya. Konsep pemasaran dipilih berasakan kepada kessediaan produk dan keupayaan fasilitas pemasaran oleh industri tersebut, serta bersesuain pula dengan faktor-faktor persekitaran pasaran dan pembelian oleh pengguna sasaran.

Secara umum, terdapat lima konsep pemasaran, yaitu:

a. Konsep Pengeluaran

Konsep pengeluaran adalah berasakan kepercayaan bahwa pengguna lebih berminat membeli produk yang berharga murah serta mudah diperoleh. Oleh itu, industri akan memberi tumpuan kepada kecekapan pengeluaran produk dalam jumlah yang tinggi, menggunakan kos sumber yang rendah, menawarkan harga jualan yang murah dan mengadakan liputan pengedaran yang luas.

b. Konsep Produk

Konsep produk adalah berasakan kepada prinsip bahwa pengguna akan menghargai dan lebih mengutamakan produk yang menawarkan kualitas, prestasi dan ciri-ciri inovatif yang terbaik. Untuk itu, industri akan memmberi lebih tumpuan kepada mereka cipta produk yang berprestige mempunyai atribute dan value yang terbaik dalam kelasnya yang tersendiri serta 
memyempurnakan pengeluarannya walaupun dengan harga yang tinggi.

c. Konsep Jualan

Konsep jualan berorientasikan menjual produk melalui kaedah pemasran yang lebih agresif. Industri yang memilih konsep ini percaya bahwa pengguna mempunyai minat yang rendah untuk membeli produknya serta tidak akan membeli produk dengan mencakupi sebagaimana diharapkan sekirannya tidak didorong. Konsep ini dipraktik apabila industri mempunyai kelebihan keupayaan dalam menyediakan produk serta berkeyakinan bahwa ia mempunyai fasilitas yang cukup untuk melaksanakan aktiviti pemasaran yang dirancang.

d. Konsep Pemasaran

Konsep Pemasaran berbeda dengan tiga konsep yang dinyatakan di atas. Konsep ini berorientasikan memenuhi keperluan dan kemahuan pengguna dengan efektif, sedangkan tiga konsep sebelumnya berorentasikan kepentingan industri untuk menjual produk. 
e. Konsep Kesejahteraan

Konsep Kesejahteraan adalah langsungan daripada Konsep Pemasaran dimana ia ditambah dengan unsurunsur kepekaan industri terhadap kesejahteraan pengguna serta masyarakat keseluruhan.

\subsection{Strategi dan taktik Pemasaran}

Ada beberapa strategi pemasaran yang dapat digunakan untuk mencapai keunggulan bersaing, diantaranya strategi penetrasi pasar, strategi pengembangan pasar, strategi pengembangan produk, dan segmentasi pasar (zimmer dan scarborough, 2002).

Strategi penetrasi pasar adalah usaha meningkatkan penjualan dari produk yang sama (lama) dan dalam pasar yang sekarang (atau lokasi yang sekarang) melalui peningkatan usaha penjualan dan periklanan. Dilain Pihak strategi pengembangan pasar adalah usaha untuk meningkatkan penjualan dengan memperkenalkan produk atau jasa yang sama (lama) kepada pasar atau segmen yang baru.

Ada beberapa syarat untuk melakukan segmentasi yang efektif, yaitu segmentnya harus dapat dikur, dijangkau, cukup besar atau cukup menguntungkan, dapat dibedakan dan dapat dilaksanakan. 
Dalam menetapkan dasar segmentasi ada dua cara yang dapat dilakukan, yaitu

Konsumen characteristic (karakteristik konsumen) yang merupakan variabel utama dalam segmentasi yang terdiri dari Segmentasi Pasar

Menurut para ahli segmentasi pasar dapat diartikan sebagai berikut :

1. Swastha \& Handoko (1997)

mengartikan segmentasi pasar sebagai kegiatan membagibagi pasar atau market yang bersifat heteron kedalam satuan pasar yang bersifat homogen

2. $\quad$ Pride \& Ferrel (1995)

mengatakan bahwa segmentasi pasar adalah suatu proses membagi pasar ke dalam segmen-segmen pelanggan potensial dengan kesamaan karakteristik yang menunjukkan adanya kesamaan perilaku pembeli.

3. Kotler, Bowen dan Makens

Pasar Terdiri dari pembeli dan pembeli berbeda-beda dalam berbagai hal yang bisa membeli dalam keinginan,sumber daya, lokasi, sikap membeli, dan kebiasaan membeli. Karena masing-masing memiliki kebutuhan dan keinginan yang unik, masing-masing pembeli merupakan pasar potensial tersendiri. Oleh sebab itu penjual idealnya mendesain program pemasarannya tersendiri bagi masing-masing pembeli. Segmentasi yang lengkap membutuhkan biaya yang tinggi, dan kebanyakan 
pelanggan tidak dapat membeli produk yang benar-benar disesuaikan dengan kebutuhan. Untuk itu, perusahaan mencari kelas-kelas pembeli yang lebih besar dengan kebutuhan produk atau tanggapan membeli yang berbedabeda. Segmen pasar terdiri dari kelompok pelanggan yang memiliki seperangkat keinginan yang sama.

Sementara itu Kotler, Kartajaya, Huan dan Liu (2003) menyatakan bahwa segmentasi adalah melihat pasar secara kreatif, segmentasi merupakan seni mengidentifikasi dan memanfaatkan peluang-peluang yang muncul di pasar. Pada saat yang sama segmentasi merupakan ilmu (science) untuk memandang pasar berdasarkan variabel geografis,demografis, psikografis dan perilaku.

Jadi, segmentasi pasar adalah kegiatan membagi suatu pasar menjadi kelompok-kelompok pembeli yang berbeda yang memiliki kebutuhan, karakteristik, atau perilaku yang berbeda yang mungkin membutuhkan produk atau bauran pemasaran yang berbeda. Atau segmentasi pasar bisa diartikan proses pengidentifikasian dan menganalisis para pembeli di pasar produk, menganalisa perbedaan antara pembeli dipasar. Atau bisa juga diartikan sebagai kegiatan membagi-bagi pasar yang bersifat heterogen dari suatu produk kedalam satuan-satuan pasar (segmen pasar) yang bersifat homogen. Berdasarkan definisi diatas diketahui bahwa pasar suatu produk tidaklah homogen, akan tetapi pada kenyataannya adalah heterogen. Pada dasarnya segmentasi pasar adalah suatu strategiyang 
didasarkan pada falsafah manajemen pemasaran yang orientasinya adalah konsumen. Dengan melaksanakan segmentasi pasar, kegiatan pemasaran dapat dilakukan lebih terarah dan sumber daya yang dimiliki perusahaan dapat digunakan secara lebih efektif dan efisien dalam rangka memberikan kepuasan bagi konsumen.

Segmentasi tersebut memiliki peran penting karena beberapa alasan;

1. Segmentasi memungkin perusahaan untuk lebih fokus dalam mengalokasikan sumberdaya. Dengan membagi pasar menjadi segmen-segmen akan memberikan gambaran bagi perusahaan untuk menetapkan segmen mana yang akan dilayani. Selain itu segmentasi memungkin perusahaan mendapatkan gambaran yang lebih jelas mengenai peta kompetisi serta menentukan posisi pasar perusahaan.

2. Segmentasi merupakan dasar untuk menentukan komponenkomponen strategi. Segmentasi yang disertai dengan pemilihan target market akan memberikan acuan dalam penentuan positioning.

3. Segmentasi merupakan faktor kunci untuk mengalahkan pesaing, dengan memandang pasar dari sudut yang unik dan cara yang berbeda dari yang dilakukan pesaing. 
Manfaat segmentasi pasar:

1. Mempertahankan dan meningkatkan tingkat penjualan, operasi perusahaan dalam jangka panjang dapat berkelanjutan dan kompetitif

2. Perusahaan akan dapat mendeteksi secara dini dan tepat mengenai kecendrungan-kecendrungan dalam pasar yang senantiasa berubah

3. Dapat mendesain produk yang benar-benar sesuai permintaan pasar

4. Dapat menentukan promosi yang paling efektif

Kelemahan segmentasi pasar:

1. Biaya produksi akan lebih tinggi, karena jangka waktu proses produksi lebih pendek

2. Biaya riset pasar akan bertambah searah dengan banyaknya ragam dan manfaat segmen pasar yang ditetapkan

3. Biaya promosi akan lebih tinggi, ketika jumlah media tidak menyediakan diskon

4. Kemungkinan akan menghadapi pesaing yang membidik segmen serupa

\section{Dasar Segmentasi}

Dalam menetapkan dasar segmentasi ada dua cara yang dapat dilakukan, yaitu Konsumen characteristic (karakteristik 
konsumen) yang merupakan variabel utama dalam segmentasi yang terdiri dari :

\section{Segmentasi Geografi}

Membagi segmen pasar secara geografis artinya pengelompokan konsumennya didasarkan atas tempat, lokasi dan daerahnya. Dengan demikian segmentasinya dapat dikembangkan menjadi beberapa bagian seperti berikut:
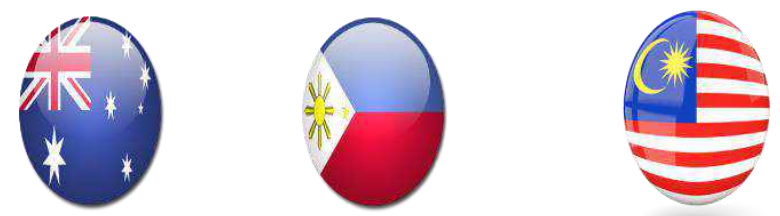

Dalam hal ini dapat berbentuk negara, negara bagian, provinsi pulau seperti:Jawa, Kalimantan, Sulawesi, Irian Jaya, Nusa Tenggara Barat, NusaTenggara Timur, Riau.

Daerah Kepadatan Penduduk. Dalam hal ini segmentasi dilihat dari jumlah kepadatan penduduk seperti misalnya Jakarta, Semarang, Surabaya, Medan dan Makassar dan kota besarlainnya yang dijadikan target market setelah melakukan segmentasi pasar.

Iklim. Dalam hal ini sementasi didasarkan atas iklim daerahnya, misalnya daerah tropis, Sub-tropis, Sedang/dingin Contoh:

Kentucky Fried Chicken (KFC), berasal dari Amerika memasarkan produknya keberbagai Negara tetapi dengan 
rasa khas di berbagai tempat Negara tersebut. Misalnya di Indonesia yang dibuat lebih pedas

Sepatu ski akan dijual di wilayah tertentu saja, tidak akan dijual di wilayah yang beriklim tropis yang memiliki dua musim saja.

Jumlah penjualan AC di AsiaTenggara jauh lebih besar disbanding Eropa disebabkan perbedaan cuaca panas dan dingin.

\section{Segmentasi Demografi}

Segmentasi berdasarkan demografi adalah berkaitan dengan masalah kependudukan. Segmentasi ini memisahkan pada variable demografis seperti umur, jenis kelamin, besarnya /jumlah anggota keluarga, siklus hidup keluarga, pendapatan, pendidikan, pekerjaan, agama, ras dan kebangsaan. Bentuk segmentasi yang dapat dilakukan antara lain:

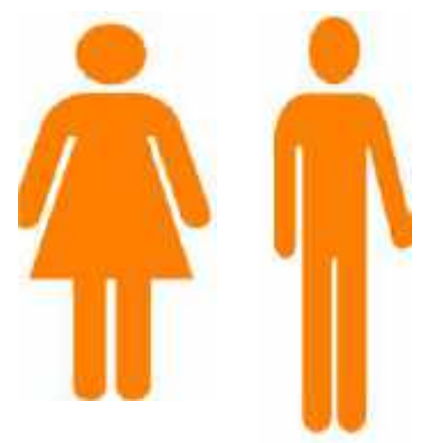

Umur Kurang dari 6, 6-11, 12-20, 21-30, 31-40, 41-50, 51-60, lebih dari 61.Misalnya, sabun mandi Cusson ditujukan bukan 
hanya untuk orang Dewasa tetapi ada juga yang untuk bayi/anak-anak.

Jenis Kelamin Pria, Wanita. Segmentasi ini banyak diaplikasikan untuk pakaian, kosmetik, asesoris rambut, majalah, rokok, mobil. Misalnya, parfum Burt untuk -pria dan channel untuk wanita.

Besarnya Keluarga1-2, 3-4, 5-7, 8 atau lebih

Tipe Keluarga Keluarga inti (suami istri), keluarga kecil (suami,istri, anak), keluarga besar (suami, istri, anak, orang tua, saudara). Aplikasi dalam pemasaran adalah adanya kemungkinan bagi keluarga besar untuk berbelanja bersama dan dalam jumlah besar.

Siklus Hidup Keluarga Muda, tidak kawin; muda, kawin, tidak ada anak; muda, kawin, anak terkecil kurang dari 6 tahun; muda, kawin, anak terkecil 6 tahun atau lebih; tua,kawin, ada anak; tua, kawin, tidak ada anak di bawah 18 tahun; tua, tidak kawin; lain-lain.

Pendapatan Kurang dari Rp300.000,00; Rp300.000,00 Rp750.000,00; Rp750.001,00-Rp200.000,00; Rp 1.200.00; Rp 1.700.000,00; di atas 1.700.000,00. Biasanya diterapkan untuk kendaraan, kapal, pakaian, kosmetik, liburan dan perjalanan.

Pekerjaan Profesional, ahli teknik; manajer; ofisial, pemilik, tenaga administrasi, tenaga penjual, tukang, mandor, operator, petani, ibu rumah tangga, mahasiswa,purnawirawan, pelajar, penganggur. 
Pendidikan SD atau kurang, tidak lulus SMP, lulus SMP, tidak lulus SMA, lulus SMA,tidak lulus Universitas, sarjana, master ke atas.

Agama Kristen, Katolik, Islam, Hindu, Budha

Ras Kebangsaan Amerika, Inggris, Prancis, Indonesia, Jepang.

Contoh Segmentasi Demografi:

Susu Sustagen, membagi produknya kedalam kelompok umur (bayi balita, dan diatas lima tahun)

Games untuk anak-anak dan remaja

Sepatu pria dan Wanita

Majalah Kartini dan Femina untuk Wanita

Mobil Toyota Kijang, membidik pasarnya di Indonesia untuk mayoritas konsumen yang sudah berkeluarga

Toyota Alphard, pasar sasarannya keluarga menengah keatas dimana konsumen mengutamakan prestige serta kenyamanan Bank Syariah (Muamalat, Mandiri Syariah, BRI Syariah, dll, pasar sasarannya umat Islam dengan slogan-slogan yang berkaitan dengan Agama

\section{Psychographic Segmentation (Segmentasi Psikografis)}

Pada Psychographic segemtation pengelompokan didasarkan pada karakteristik setiap konsumen, seperti 
motivasi, kepribadian, persepsi,interest, minat dan sikap, atau gaya hidup.

consumer responses (respon konsumen) yang terdiri dari Benefit segmentation (segmentasi manfaat) yaitu pengelompokan yangdi dasarkan kepada manfaat yang diharapkan konsumen dari suatu produk atau jasa, use occasion (saat pemakaian) dan Brand atau merek. Dengan ini konsumen akan dikelompokkan berdasarkan respon mereka terhadap produk atau jasa, seperti ada konsumen yang mementingkan kualitas dan ada konsumen yang mementingkan harga yang murah. Segmentasi manfaat menuntut ditemukannya manfaat utama yang dicari orang dalam kelas produk, jenis orang yang mencari setiap manfaat dan merek utama yang mempunyai setiap manfaat. Perusahaan dapat menggunakan segmentasi manfaat untuk memperjelas segmen manfaat yang mereka inginkan, karakteristiknya serta merek utama yang bersaing. Mereka juga dapat mencari manfaat baru dan meluncurkan merek yang memberikan manfaat.

Contoh Segmentasi Psikografis:

Produsen mendesain mobil sport untuk konsumen bergaya sportif, mobil sedan lux untuk menginginkan kesan ekslusif dan mengutamakan kenyamanan

Departemen Store SOGO, melayani kelas atas 


\section{Segmentasi Behavioristis/Perilaku}

Pada segmentasi ini perilaku digunakan sebagai variable utama dalam segmentasi pasar, konsumen dibagi menjadi kelompok-kelompok menurut tingkat pengetahuan, sikap , penggunaan atau tanggapannya terhadap suatu produk tertentu.

Contoh segmentasi perilaku yaitu:

Rinso, lebih dikenal di benak masyarakat karena sudah lama berdiri dan mencuci lebih bersih dari deterjen lain

\section{B. PASAR SASARAN}

Pasar Sasaran terdiri dari seperangkat pembeli yang memiliki kebutuhan dan karakteristik yang sama, yang diputuskan untuk dilayani oleh perusahaan Ada tiga alternatif strategi pemilihan pasar sasaran, yaitu:

Pemasaran tidak dibedakan/tanpa diferensiasi (undifferentiated marketing)

Pemasaran dibedakan/dengan diferensiasi/differentiated marketing)

Pemasaran terkonsentrasi (concentrated marketing)

\section{Pemasaran tanpa diferensiasi}

Perusahaan mungkin memutuskan untuk mengabaikan perbedaan-perbedaan yang ada pada tiap-tiap segmen pasar, dan masuk ke pasar secara keseluruhan dengan satu tawaran 
Contoh air minum aqua, pemasaran coca cola company hanya berupa satu minuman dalam satu ukuran botol dengan satu rasa untuk semua orang

\section{Pasar dengan Diferensiasi}

Dimana sebuah perusahaan memutuskan untuk membidik beberapa segmen pasar dan mendesain tawaran yang terpisah

Contoh:

Parfum chanel wanita dan parfum chanel laki -laki

\section{Pemasaran terkonsentrasi}

Pemasaran terkonsentrasi, dimana sebuah perusahaan memilih untuk meraih pangsa pasar yang besar pada satu atau dua segmen saja

Contoh penerbit salemba empat pada pasar bacaan ekonomi dan bisnis

\section{Posisi Pasar (Positioning)}

Posisi pasar adalah cara produk didefenisikan oleh konsumen berdasarkan beberapa atribut penting tempat yang diduduki produk dalam benak konsumen dibandingkan hubungan produk-produk pesaing.

Positioning suatu produk menuntut perusahaan untuk menanamkan keunikan manfaat dan diferensiasi merek kedalam benak pelanggan. Contoh: Dalam pasar mobil, 
Mercedes dan Cadilac berdasarkan kemewahan, BMW berdasarkan kinerja, Volvo sangat kuat memposisikan pada keselamatan

\subsection{Konsep Bauran Pemasaran}

Menurut William J.Stanton, pengertian marketing mix secara umum adalah sebagai berikut: marketing mix adalah istilah yang dipakai untuk menjelaskan kombinasi empat besar pembentuk inti system pemasaran sebuah organisasi. Keempat unsur tersebut adalah penawaran produk/ jasa, struktur harga, kegiatan promosi, dan system distribusi.

Keempat unsure atau variable bauran pemasaran (Marketing Mix) tersebut atau yang disebut four p's adalah sebagai berikut:

1. Strategi Produk

2. Strategi Harga

3. Strategi Penyaluran/ Distribusi

4. Strategi Promosi

Marketing mix yang dijalankan harus sesuai dengan situasi dan kondisi perusahaan. Disamping itu, marketing mix merupakan perpaduan dari factor-

Faktor yang dapat dikendalikan perusahaan untuk mempermudah buying decision, maka variable-variabel marketing mix diatas tadi dapat dijelaskan sedikit lebih mendalam sebagai berikut: 
1. Produk ( Jasa )

Kebijaksanaan mengenai produk atau jasa meliputi barang /jasa yang akan ditawarkan perusahaan, pelayanan khusus yang ditawarkan perusahaan guna mendukung penjualan barang dan jasa, dan bentuk barang ataupun jasa yang ditawarkan. Produk merupakan elemen yang paling penting, sebab dengan inilah perusahaan berusaha untuk memenuhi “ kebutuhan dan keinginan " dari konsumen, namun keputusan itu tidak terdiri sebab produk/jasa sangat erat hubungannya dengan target market yang dipilih. Sedangkan sifat dari produk/jasa tersebut adalah sebagai berikut:

a. Tidak berwujud

Jasa mempunyai sifat tidak berwujud karena tidak bisa dilihat,dirasa,diraba,didengar atau dicium, sebelum ada transaksi pembelian.

b. Tidak dapat dipisahkan

Suatu produk jasa tidak dapat dipisahkan dari sumbernya, apakah sumber itu merupakan orang atau benda. Misalnya jasa yang diberikan oleh sebuah hotel tidak akan bisa terlepas dari bangunan hotel tersebut

c. Berubah-ubah Bidang jasa sesunggunya sangat mudah berubah-ubah, sebab jasa ini sangat tergantung kepada siapa yang menyajikan, kapan 
disajikan dan dimana disajikan. Misalnya jasa yang di berikan oleh sebuah hotel berbintang satu akan berbeda dengan jasa yang diberikan oleh hotel berbintang tiga.

\section{d. Daya Tahan}

jasa tidah dapat disimpan. Seorang pelanggan yang telah memesan sebuah kamar hotel akan dikenakan biaya sewa, walaupun pelanggan tersebut tidak menepati kamar yang ia sewa.

\section{Harga (Price)}

Setiap perusahaan selalu mengejar keuntungan guna kesinambungan produksi. Keuntungan yang diperoleh ditentukan pada penetapan harga yang di tawarkan. Harga suatu produk atau jasa ditentukan pula dari besarnya pengorbanan yang dilakukan untuk menghasilkan jasa tersebut dan laba atau keuntungan yang diharapkan. Oleh karena itu, penentuan harga produk dari suatu perusahaan merupakan masalah yang cukup penting, karena dapat mempengaruhi hidup matinya serta laba dari perusahaan. Kebijaksanaan harga erat kaitannya dengan keputusan tentang jasa yang dipasarkan. Hal ini di sebabkan harga merupakan penawaran suatu produk atau jasa. Dalam penetapan harga, biasanya didasarkan pada suatu kombinasi barang/jasa ditambah dengan beberapa jasa lain serta keuntungan yang memuaskan. Berdasarkan harga barang yang di tetapkan ini konsumen akan mengambil 
keputusan apakah dia mengambil keputusan apakah dia membeli barang tersebut atau tidak. Juga konsumen menetapkan berapa jumlah barang / jasa yang harus dibeli berdasarkan harga tersebut. Tentunya keputusan dari konsumen ini tidak hanya berdasarkan pada harga semata, tetapi banyak juga faktor lain yang menjadi pertimbangan, misalnya kualitas dari barang atau jasa, kepercayaan terhadap perusahaan dan sebagainya. Hendaknya setiap perusahaan dapat menetapkan harga yang paling tepat, dalam arti yang dapat memberikan keuntungan yang paling baik, baik untuk jangka pendek maupun jangka panjang.

\section{Saluran Distribusi ( Place )}

Setelah perusahaan berhasil menciptakan barang atau jasa yang dibutuhkan dan menetapkan harga yang layak, tahap berikutnya menentukan metode penyampaian produk atau jasa ke pasar melalui rute-rute yang efektif hingga tiba pada tempat yang tepat, dengan harapan produk / jasa tersebut berada di tengah tengah kebutuhan dan keinginan konsumen yang haus akan produk / jasa tersebut. Yang tidak boleh di abaikan dalam langkah kegiatan memperlancaar arus barang / jasa adalah memilih jalur distribusi (Channel of Distribution). Masalah pemilihan saluran distribusi adalah masalah yang berpengaruh bagi marketing, karena kesalahan dalam memilih dapat 
menghambat bahkan memacetkan usaha penyaluran produk/jasa dari produsen ke komsumen. Distributordistributor atau penyalur ini bekerja aktif untuk mengusahakan perpindahan bukkan hanya secara fisik tapi dalam arti agar jasa-jasa tersebut dapat diterima oleh konsumen. Dalam memilih saluran distribusi ini ada beberapa hal yang perlu dipertimbangkan, yaitu sebagai berikut :

a. Sifat pasar dan lokasi pembelian

b. Lembaga-lembaga pemasaran terutama pedagangpedagang perantara

c. Pengendalian persediaan, yaitu menetapkan tingkat persediaan yang ekonomis.

d. Jaringan pengangkut

Saluran distribusi jasa biasanya menggunakan agen travel untuk menyalurkan jasanya kepada konsumen. Jadi salah satu hal yang penting untuk diperhatikan dalam kebijaksanaan saluran distribusi itu sendiri dengan memperhitungkan adanya perubahan pada masyarakat serta pola distribusi perlu mengikuti dinamika para konsumen tadi.

\section{Promosi ( Promotion)}

Aspek ini berhubungan dengan berbagai usaha untuk memberikan informasi pada pasar tentang produk / jasa yang dijual, tempat dan saatnya. Ada beberapa cara menyebarkan informasi ini, antara lain periklanan, 
(advertising), penjualan pribadi ( Personal Swlling), Promosi Penjualan (Sales Promotion) dan publisitas ( Publicity).

a. Periklanan (Adveristing ) : merupakan alat utama bagi pengusaha untuk mempengaruhi konsumennya. Periklanan ini dapat dilakukan oleh prngusaha lewat surat kabar, radio, majalah, bioskop, telivisi, ataupun dalam bentuk poster-poster yang dipasang dipinggir jalan atau tempat-tempat strategis.

b. Penjualan Pribadi (Personal Selling) : merupakan kegiatan perusahaan untuk melakukan kontak langsung dengan calon konsumennya. Dengan caalon konsumennya. Dengan kotak langsung ini diharapkan akan terjadi hubungan atau interaksi yang positif antara pengusaha dengan calon konsumennya itu. Yang termasuk dalam personal selling adalah : door to door selling, mail order, telephone selling, dan direct selling.

c. Promosi Penjualan (Salesman Promotion) : merupakan kegiatan perusahaan untuk menjajakan produk yang dipasarkannya sedmikian rupa sehingga konsumen akan mudah untuk melihatnya dan bahkan dengan cara penempatan dan pengaturan tertentu, maka produk tersebut akan menarik perhatian konsumen.

d. Publisitas ( Publicity) : merupakan cara yang biasa digunakan juga oleh perusahaan untuk membentuk pengaruh secara tidak langsung kepada konsumen, agar 
mereka menjadi tahu, dan menyenangi produk yang dipasarkannya, hal ini berbeda dengan promosi, dimana didalam melakukan publisitas perusahaan tidak melakukan hal.

\section{Rangkuman}

1. Kotler (2003) mengatakan bahwa pemasaran sebagai suatu proses sosial dan manajerial dimana individu dan kelompok mendapatkan apa yang mereka butuhkan dan inginkan dengan menciptakan, menawarkan dan mempertukarkan produk yang bernilai dalam pasar. Pemasaran melibatkan banyak kegiatan yang berbeda yang menambah pada saat produk bergerak melalui sistem tersebut.

2. segmentasi pasar adalah kegiatan membagi suatu pasar menjadi kelompok-kelompok pembeli yang berbeda yang memiliki kebutuhan, karakteristik, atau perilaku yang berbeda yang mungkin membutuhkan produk atau bauran pemasaran yang berbeda

Pertanyaan untuk Diskusi

1. Jelaskan konsep pemasaran

2. Jelaskan strategi dan taktik pemasaran

3. Jelaskan konsep bauran pemasaran 


\section{BAB XII \\ PERKEMBANGAN, PENGEMBANGAN \\ KEWIRAUSAHAAN DAN UMKM}

Tujuan Pembelajaran:

Setelah mempelajari bab ini calon wirausaha diharapkan dapat:

1. Menjelaskan Perkembangan Kewirausahaan

2. Menjelaskan Pengembangan Kewirausahaan

3. Menjelaskan jenis-jenis usaha kecil berdasarkan peluang yang ada

4. Menjelaskan Pengertian UMKM

5. Menjelaskan Faktor-Faktor Yang Mempengaruhi Kegalalan UMKM

6. Mejelaskan Faktor Pendukung Keberhasilan UMKM

7. permintaan barang dan jasa

8. Menjelaskan Pengembangan UMKM Melalui Pembinanaan Oleh Pemerintah

\subsection{Perkembangan Kewirausahaan}

Kewirausahaan mulai dikenai populer pada awal abad ke-18 pada tahun 1755 oleh seorang Irlandia bernama Richard Cantillon yang berdiam di Perancis merupakan orang yang pertama menggunakan istilah wirausaha.

Seorang ahli manajemen, Peter Drucker dalam bukunya Innovation and Entrepreneurship di Amerika, menyimpulkan bahwa telah terjadi pergeseran dari masa ekonomi berdaarkan manajemen ke ekonomi berdasarkan kewirausahaan. 
Misalnya, dalam hal penyediaan lapangan kerja, pencipta lapangan kerja yang lama, yaitu organisasi besar bahkan mengurangi tenaga kerjanya, sedangkan organisasi baru berskala kecil dan menengah diwarnai oleh kewirausahaan dari pendiri dan pemimpinnya menjadi penyedia lapangan kerja baru.

\subsection{Pengembangan Kewirausahaan}

Pada era dunia usaha yang makin kompetitif, seseorang wirausaha harus memiliki keceradasan untuk menangkap peluang usaha. Dunia usaha zaman sekarang telah melahirkan kreatifitas dan inovasi yang cukup tinggi. Mampu memanfaatkan sesuatu untuk dikembangkan menjadi sebuah peluang usaha.

Seperti sebuh pengembangan, wirausahwan telah menciptakan berbagai pengembangan dalam dunia usahanya, seperti sosial entrepreneurship, technopreneurship, leadpreneurship, beautypreneurship, dan cyberpreneurship.

\section{a. Technopreneurship}

Secara terminologi technopreneurship merupakan istilah bentkan dari dua kata, yakni teknologi dan enterpreneurship. Secara umum, kata teknologi digunakan untuk merujuk pada penerapan praktis ilmu pengetahuan ke dunia industri atau sebagai kerangka pengetahuan yang digunakan untuk 
menciptakan alat-alat, untuk mengembangkan keahlian dan mengolah materi guna memecahkan persoalan yang ada.

Technopreneurship merupakan proses dan pembentukan usaha baru yang melibatkan teknologi sebagai basisnya dengan harapan bahwa penciptaan strategi dan inovasi yang tepat kelak bisa menempatkan teknologi sebagai salah satu faktor untuk pengembangan ekonomi nasional. Contoh usaha yang berbasis teknologi sbb:

Gambar 2. Mesin pembuat susu kedelai
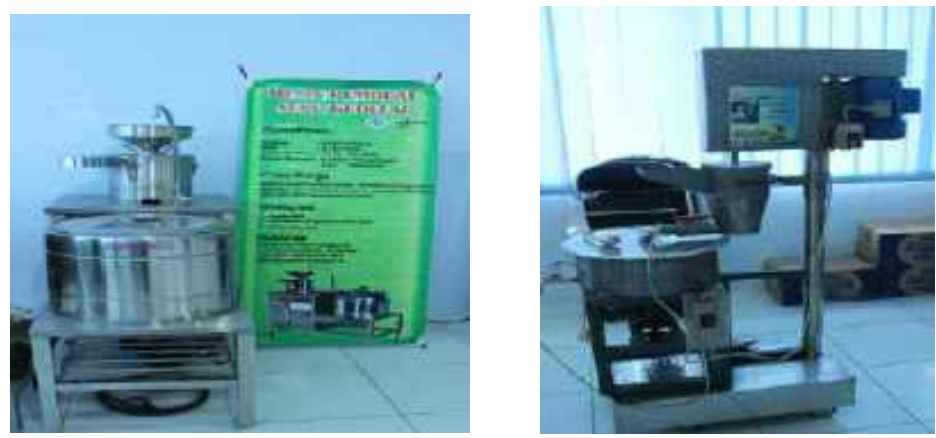

b. Kewirausahaan Sosial (Sosial Entrepreneurship)

Wirausaha sosial bertujuan meningkatkan nilai kesejahteraan anggota masyarakat yang menjadi target pelayanannya.

Salah satu contoh wirausaha sosial adalah Mohammad Yunus, pendiri Grameen Bank, pionir sistem kredit mikro yang ditujukan kepada para wanita pengusaha skala mikro. Pada tahun 2006 ia terpilih sebagai penerima hadiah nobel perdamaian. 
Salah satu entrepreneurship sosial di kota medan yakni Alween Ong.

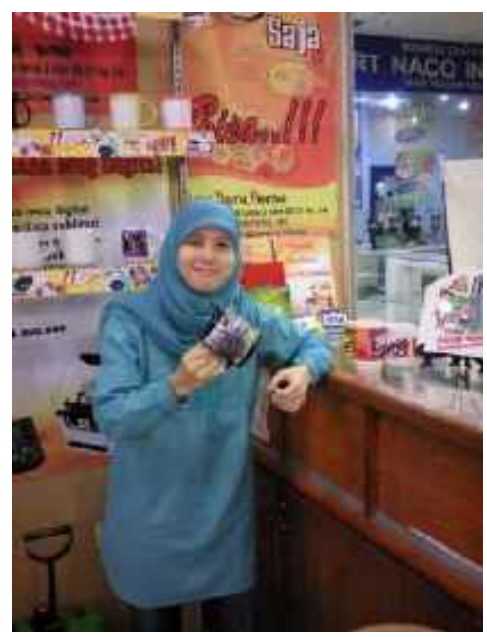

Lahir di pesisir Tebing Tinggi anak dari seorang Nelayan yang mempunya usaha digital printing yang mempunyai omzet lebih dari Rp. 50 juta sebulan.. Alween kerab sekali membagi pengetahuan kepada wirausahawan muda di Medan. Dan sebanyak persen dari pendapatan Al Companya Indonesia digunakan untuk program kemanusiaan.

\subsection{Jenis-Jenis Usaha Kecil Berdasarkan Peluang Yang} Ada

Perkembangan dunia usaha di Indonesia mengarah pada bermunculnya model-model usaha di Indonesia mengarah pada bermunculannya model-model usaha kecil dan menengah, diantaranya usaha jasa, usaha eceran, retail, usaha distribusi, agribisnis, manufaktur Di luar bidang-bidang usaha tersebut, kecendrungan yang ada pada usaha kecil di Indonesia 
mengarah pada bermunculnya model-model usaha kecil dan menengah.

Diantara usaha-usaha tersebut adalah:

a Usaha Jasa

Usaha Jasa merupakan yag terbesr dan cepat pertumbuhannya dalam dunia usaha kecil. Jasa membawa keuntungan yang sangat besar bagi wirausaha kecil yang mampu berinovasi tinggi. Misalnya di bidang jasa pendidikan, penyewaan mobil, konsultan manajemen, penyewaan mobil, konsultan manajemen, periklanan, rumah produksi, layanan jasa internet jasa outsourcing, bidang keamanan dan cleaning service.

b. Usaha eceran

Adalah bentuk bisnis kecil yang ditekuni oleh wirausaha kecil. Usaha eceran adalah salah satunya usaha yang menjual produk manufaktur yang langsung kepada konsumen.

Contoh saleh kurnia

c. Usaha distribusi

Usaha ini salah satunya usaha yang membeli barang dari pabrik atau produsen dan menjual kepada eceran.

Contoh PT. Indomarco yang bergerak bidang jasa distribusi produk konsumesi yang kini juga mulai merambah usaha eceran. 
d. Usaha pertanian/Agribisnis

Pertanian ba merupakan bentuk usaha kecil yang tertua. Pada awalnya, hasil pertanian digunakan untuk memenuhi kebutuhan sendiri dan keluarga, namun lama kelamaan menjadi sebah usaha yang cukup besar.

e. Usaha Manufaktur

Merupakan suatu usaha kecil yang saat ini sering kali dikategorikan masuk dalam jenis idustri kreatif contoh kerajinan tangan, percetakan dll. Kaos oblong merek Dagadu Djogdja adalah contoh usaha yang awalnya merupakan penyaluran hobi mahasiswa arsitektur yang pandai dlam hal desain grafis. Produk yang unik dan lucu namun cerdas dituangkan dlam bentuk cindramata alternatif dari yogya mengundang daya tarik sendiri.
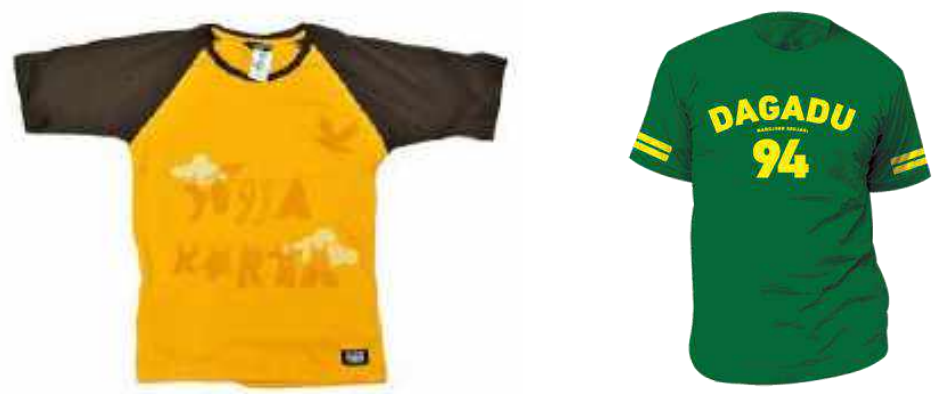

\subsection{Usaha Mikro Kecil dan Menengah}

Pelaku Usaha Mikro, Kecil dan Menengah di Indonesia telah menunjukkan ketahanan dalam menghadapi krisis ekonomi yang terjadi di saat sekarag maupun dimasa lalu. 
Fakta tersebut menunjukkan bahwa usaha mikro, usaha kecil dan usaha menengah mampu menghadapi pengaruh negatif dari kondisi perekonomian dunia dan nasional yang telah mengalami krisis berkali-kali.

Berdasarkan jumlah pegawainya, suatu usaha dapat dikategorikan antara usaha mikro, usaha kecil, usaha menengah dan usaha besar. Usaha mikro, memiliki jumlah pengawai 5 orang hingga 20 orang pegawai hingga 50 orang pegawai, adapun usaha menengah biasanya memiliki pegawai antara 50 sampai 100 orang pegawai dan usaha besar biasanya memiliki pegawai lebih dari 100 orang pegawai.

Berdasarkan omzet dan batasan asetnya usaha dikategorikan menjadi empat, yaitu

1. Usaha Mikro yang memiliki aset sampai dengan Rp. 50 juta sampai dengan Rp. 200 juta.

2. Usaha Mikro dengan aset sampai dengan Rp. 200 juta dan omzet per tahun mencapai Rp 200 juta- Rp. 1 Miliar

3. Usaha Menengah dengan aset dari Rp. 200 juta - Rp. 10 Miliar dan omzet per tahun mencapai Rp. 1 Miliar sampai dengan Rp. 10 Miliar.

4. Usaha besar/kolongmerat dengan aset sampai dengan > Rp. 10 Miliar dan omzet per tahun lebih dari Rp. 50 Miliar 


\subsection{Faktor-Faktor Yang Mempengaruhi Kegalalan UMKM}

Ada empat fakor yang mendorong gagalnya Usaha Mikro Kecil dan Menegah antara lain:

a. Banyak usaha UMKM yang dikelola oleh manajer yang kurang mampu dan kurang berpengalaman dalam menjalankan tugasnya

b. Kurang fokusnya atau perhatian yang mendukung dari pihak pengusaha itu sendiri.

c. Masih lemahnya sistem kontrol/pengawasan. Sehingga menyebabkan kerugian dan penggunaan sumber daya yang berlebihan.

d. Kurang modal untuk menjalankan usaha.

\subsection{Faktor Pendukung Keberhasilan UMKM}

Faktor-faktor yang mendukung keberhasilan Usaha Kecil dan Menengah antara lain:

a. Pekerja yang ulet dan pekerja kers

b. Dukungan faktor eksternal berupa peningkatan permintaan barang dan jasa

\subsection{UKM dan Pengembangannya Melalui Pembinanaan Oleh Pemerintah}

Munculnya UU. No. 20/2008 tentang usaha mikro, kecil dan menengah mendorong beberapa instansi pemerintah dan BUMN saat ini mulai mengembagkan program pendampingan 
dan pembinaan terhadap UMKM, diantaranya program pembiayaan produktif koperasi dan usaha mikro pola syariah, program perkuatan permodalan KJKs/UJKS yang dilaksankan oleh kantor kementrian negara koperasi dan usaha kecil menengah.

Bahkan di kementrian negara koperasi dan usaha kecil menengah juga dibentk oleh lembaga noneselon, yaitu lembaga pengelola dana berulir koperasi, usaha mikro, kecil dan menengah yang bertanggung jawab langsung kepada menteri negara koperasi dan usaha kecil menengah dan tugas mengeelola dana bergulir dan pembiayaan bagi usaha kecil dan menengah.

Di Indonesia telah berdiri sekitar lebh dari 30 Inkubator Bisnis yang dikelola oleh lingkungan Perguruan Tinggi dan 8 unit inkubasi bisnis berada di lingkungan industri yang semuanya tergabung dalam Asosiasi Inkubator Bisnis Indonesia (AIBI)

Beberapa Inkubator Bisnis di Lingkungan Swasta/Industri:

1. Pinbuk (Jakarta)

2. YDBA (Jakarta)

3. WPU (Bandung)

4. WPU (Surabaya)

5. KPKUD (Sidoarjo)

6. LIK (Gresik)

7. PT. Freeport Indonesia (Timika) 
Inkubator Binis di Lingkungan perguruan Tinggi”

1. ITP-BPPT (Serpong)

2. Unika dan KKB (Jakarta)

3. PIB STIAMI (Jakarta)

4. IBB-STMB (Bandung)

5. PIBI Ikopin (Sumedang)

6. PIB Unpad (Bandung)

7. PIB TB (Bandung)

8. PIBI ITB (Bandung)

9. UKM Center-FEUI (Depok)

10. REDBIC-UNS (Solo)

11. Universitas Muhammadiyah Yogyakarta

12. Universias Widya Mataram (Yogyakarta)

13. Universitas Jember

14. SBIC $=$ ITS (Surabaya)

15. IPK-Unmer (Malang)

16. Universitas Riau

17. Universitas Andalas (Padang)

18. USU (Medan)

19. Universitas Lambung Mangkurat (Kalimantan Selatan)

20. Universitas Mataram (NTB)

21. Universitas Sam Ratulangi (Sulawesi)

22. Universitas Hasanuddin (Makasar)

23. Universitas Cendrawasih (Irian Jaya) 
Keberhasilan dari sistem inkubasi bisnis ditentukan oleh tiga siklus kegiatan yang saling terkait yaitu perencanaan tujuan, seleksi tenant dan sponsor, keterkaitan dengan pusat riset/pedidikan, dan masyarakat profesional/bisnis, faisilitas fisik, dukungan kebijakan dan legalitas, operasionalisasi (tim manajemen), seleksi kelompok wirausaha sesuai dengan potensinya, peningkatan nilai tambah perusahaan mobilitasi dana untuk inkubator dan tenant, dan kinerja pemantauan (dampak kinerja inkubator dan perencanaan strategik).

\section{Rangkuman}

1. Berdasarkan omzet dan batasan asetnya usaha dikategorikan menjadi empat, yaitu

a. Usaha Mikro yang memiliki aset sampai dengan Rp. 50 juta sampai dengan Rp. 200 juta.

b. Usaha Mikro dengan aset sampai dengan Rp. 200 juta dan omzet per tahun mencapai Rp 200 juta- Rp. 1 Miliar

c. Usaha Menengah dengan aset dari Rp. 200 juta - Rp. 10 Miliar dan omzet per tahun mencapai Rp. 1 Miliar sampai dengan Rp. 10 Miliar.

d. Usaha besar/kolongmerat dengan aset sampai dengan > Rp. 10 Miliar dan omzet per tahun lebih dari Rp. 50 Miliar 
2. Faktor-faktor yang mempengaruhi kegagalan UMKM

a. Banyak usaha UMKM yang dikelola oleh manajer yang kurang mampu dan kurang berpengalaman dalam menjalankan tugasnya

b. Kurang fokusnya atau perhatian yang mendukung dari pihak pengusaha itu sendiri.

e. Masih lemahnya sistem kontrol/pengawasan. Sehingga menyebabkan kerugian dan penggunaan sumber daya yang berlebihan.

d. Kurang modal untuk menjalankan usaha.

3. Faktor-faktor yang mendukung keberhasilan Usaha Kecil dan Menengah antara lain:

a. Pekerja yang ulet dan pekerja kers

b. Dukungan faktor eksternal berupa peningkatan permintaan barang dan jasa

Pertanyaan Untuk Diskusi

1. Jelaskan Perkembangan Kewirausahaan

2. Jelaskan Pengembangan Kewirausahaan

3. Jelaskan jenis-jenis usaha kecil berdasarkan peluang yang ada

4. Jelaskan Pengertian UMKM

5. Jelaskan Faktor-Faktor Yang Mempengaruhi Kegalalan UMKM

6. Jelaskan Faktor Pendukung Keberhasilan UMKM

7. Jelaskan Pengembangan UMKM Melalui Pembinanaan Oleh Pemerintah 


\section{BAB XIII \\ PRODUK}

Tujuan Pembelajaran:

Setelah mempelajari bab ini calon wirausaha diharapkan:

1. Menjelaskan Pengertian Produk

2. Menjelaskan Tingkatan Produk

3. Menjelaskan Klarifikasi Produk

4. Menjelaskan Merek

5. Menjelaskan Daur Hidup Produk

\subsection{Pengertian Produk}

Produk adalah semua yang dapat ditawarkan kepada pasar untuk:

Diperhatikan, dimiliki, digunakan atau dikonsumsi, yang dapat memuaskan kebutuhan dan keinginan

\subsection{Tingkatan Produk}

1. Produk inti (core product) yaitu manfaat inti yang diperoleh konsumen ketika membeli produk. Contoh: seseorang membeli televisi untuk mendapatkan informasi dan hiburan

2. Produk Aktual (actual product), yaitu komponen, model, tampilan, nama merek, kemasan, ciri-ciri produk lainnya yang berkombinasi untuk memberi manfaat produk 
Contoh: Televisi yang dimeli merek Samsung dengan ukuran 32 inci, layar datar, warna yang tajam, dll

3. Produk tambahan (augmented product) yaitu pelayanan dan manfaat tambahan yang diperoleh konsumen (instalasi, pelayanan purna jual, pengiriman dll)

Contoh: Pembelian televisi mendapat pelayanan dengan diantar kerumah dan pemasangan antena, garansi satu tahun, dan perbaikan dengan cepat ketika dibutuhkan

\subsection{Klasifikasi Produk}

1. Produk Konsumen.(consummers product)

Adalah produk yang dibeli oleh konsumen akhir untuk dikonsumsi secara pribadi.

Produk konsumen ini meliputi:

2. Produk sehari-hari.(convenience product)

Adalah produk yang dibeli konsumen secara teratur, cepat, dan dengan perbandingan pada produk lain yang minimal serta usaha untuk mendapatkan produk tersebut juga minimal.

Contoh: sabun, permen, koran dan makanan siap saji

Produk Belanja (shopping product) 
Adalah barang yang frekwensi pembeliannya tidak sesering produk sehari-hari dan dalam pembeliannya konsumen melakukan perbandingan dengan produk lain berdasarkan kecocokan, kualitas, harga dan gaya.

3. Produk khusus.(specialty product). Adalah produk konsumen yang mempunyai karakteristik dan identifikasi merek yang unik sehingga kelompok pembeli yang cukup signifikan bersedia melakukan pembelian yang khusus. Contoh: mobil impor (built up) mewah, keramik dari Italy, jasa-jasa dokter dan ahli hukum.

4. Produk yang tidak dicari.(unsought product). Adalah produk yang konsumen tidak mengetahuinya tetapi tidak terfikirkan untuk membeli produk tersebut.

Contoh, obat ataupun darah untuk transfusi.

Produk Industri. (industrial product).

Adalah produk yang dibeli oleh individu atau organisasi dengan tujuan uruntuk diproses lebih lanjut atau digunakan untuk menjalankan bisnis.

Contoh: bahan-bahan baku, peralatan produksi, peralatan kantor. 


\subsection{Merek (Branding)}

Merek merupakan alat utama yang digunakan oleh pemasar untuk membedakan produk mereka dari pesaing.

\subsection{Daur Hidup Produk}

Daur hidup Product (Product life Cycle) terdiri dari :

1. Pengembangan produk

2. Perkenalan

3. Pertumbuhan

4. Kedewasaan

5. Penurunan

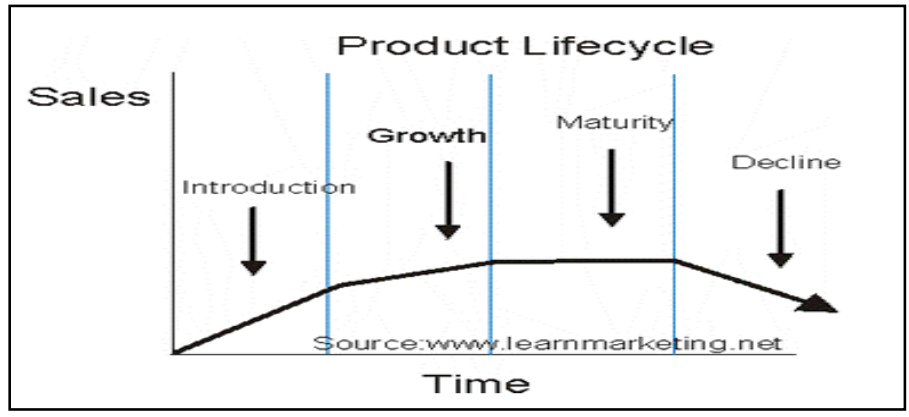

Adalah, perilaku penjualan produk dan keuntungan selama masa hidup produk tersebut. PLC ditandai oleh lima tahap:

a. Pengembangan Produk, diawali ketika perusahaan menemukan dan mengembangkan gagasan produk baru.

b. Perkenalan, adalah masa penjualan yang lambat tumbuhnya saat diperkenalkan di pasar.

c. Pertumbuhan adalah masa penerimaan pasar yang cepat dan laba sedang meningkat. 
d. Kedewasaan adalah masa pertumbuhan penjualan yang melambat karena produk telah diterima oleh sebagian besar pembeli potensial. Disini tidak tambahan laba karena biaya pemasaran meningkat untuk menahan serangan produk pesaing.

e. Penurunan adalah masa ketika penjualan dan laba merosot

\section{Rangkuman}

1. Produk adalah semua yang dapat ditawarkan kepada pasar untuk:

Diperhatikan, dimiliki, digunakan atau dikonsumsi, yang dapat memuaskan kebutuhan dan keinginan

2. Tingkatan Produk

a. Produk Inti

b. Produk Aktual

c. Produk Tambahan

Pertanyaaan untuk Diskusi

1. Jelaskan Pegertian Produk

2. Jelaskan Tingkatan Produk

3. Jelaskan Klarifikasi Produk

4. Jelaskan Merek Pengertian Merek

5. Jelaskan Daur Hidup Produk 


\section{BAB XIV \\ DESAIN (KEMASAN)}

Tujuan Pembelajaran:

Setelah mempelajari bab ini calon wirausaha diharapkan dapat:

1. Menjelaskan Arti Pengemasan

2. Menjelaskan Fungsi Kemasan

3. Menjelaskan Fungsi Strategi Kemasan

4. Menjelaskan Jenis-jenis kemasan

Produk UMKM pada umumnya tanpa merek, kemasan sangat sederhana , tanpa label terlihat seperti gambar berikut:
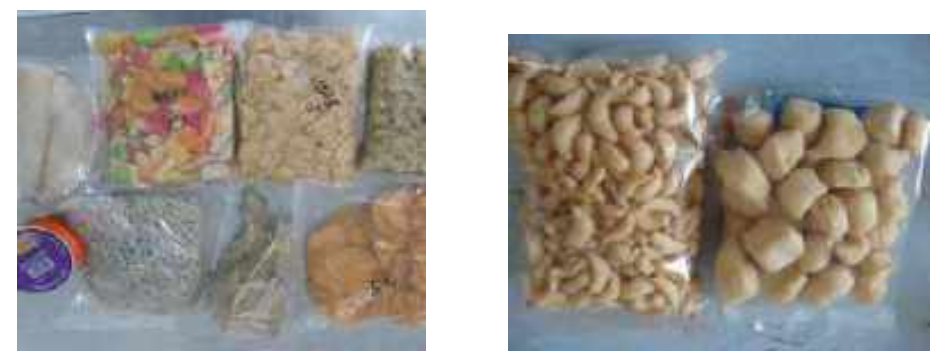

Tetapi sebaiknya kemasan harus diberi merek seperti gambar dibawah ini:

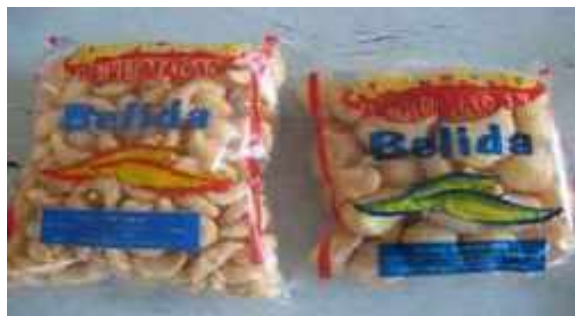




\subsection{Pengemasan}

Pengemasan merupakan kegiatan mendesain mendesain dan memproduksi wadah atau pembungkus produk. Tujuan dari pengemasan adalah sebagai berikut:

- Menampilkan atribut unik produk

- Memperkuat penampilan estetika dan nilai produk

- Mempertahankan keseragaman dalam kesatuan merek produk

- Memperkuat perbedaan antara ragam produk

- Mengembangkan bentuk kemasan berbeda yg sesuai dg kategori

- Menggunakan material baru dn mengembangkan struktur inovativ utk mengurangi biaya, lebih ramah lingkungan / meningkatkan fungsionalitas.

Kemasan harus dibuat dengan baik mungkin baik typogragi, kemasan yang tidak mudah sobek, mewakili keunggulan sesungguhnya, Isi Produk yang di labelkan misalnya Ex. Halal, Expired.

\subsection{Fungsi Kemasan}

Adapun fungsi kemasan sebagai berikut:

1. Sebagai Wadah

2. Pelindung produk didalamnya

3. Mempertahankan mutu

4. Memperpanjang masa simpan 
5. Mempermudah pemasaran/tranportasi

6. Menambah daya tarik bagi konsumen (memberi informasi dan sarana promosi)

7. Komunikasi antara produsen dan konsumen dan lainlain

\subsection{Strategi Kemasan}

Adapun strategi kemasan sebagai berikut:

1. Dibuat semenarik mungkin, punya ciri khas

2. Memuat informasi yang jelas \& jujur

3. Menarik (desain, warna, bentuk), dengan komposisi yang imbang

4. Ukuran \& material bahan sesuai kebutuhan

\subsection{Jenis-jenis kemasan}

- Kemasan ritel: plastik, kertas, gelas,

- karton, aluminium foil dan lain-lain

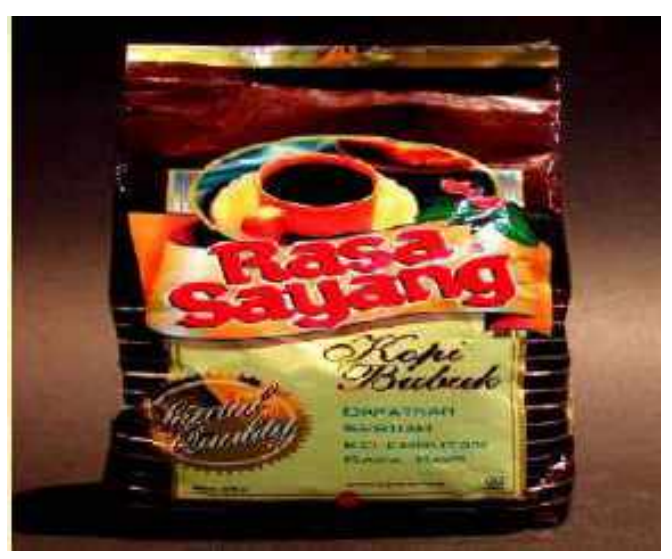


Kemasan Ritel
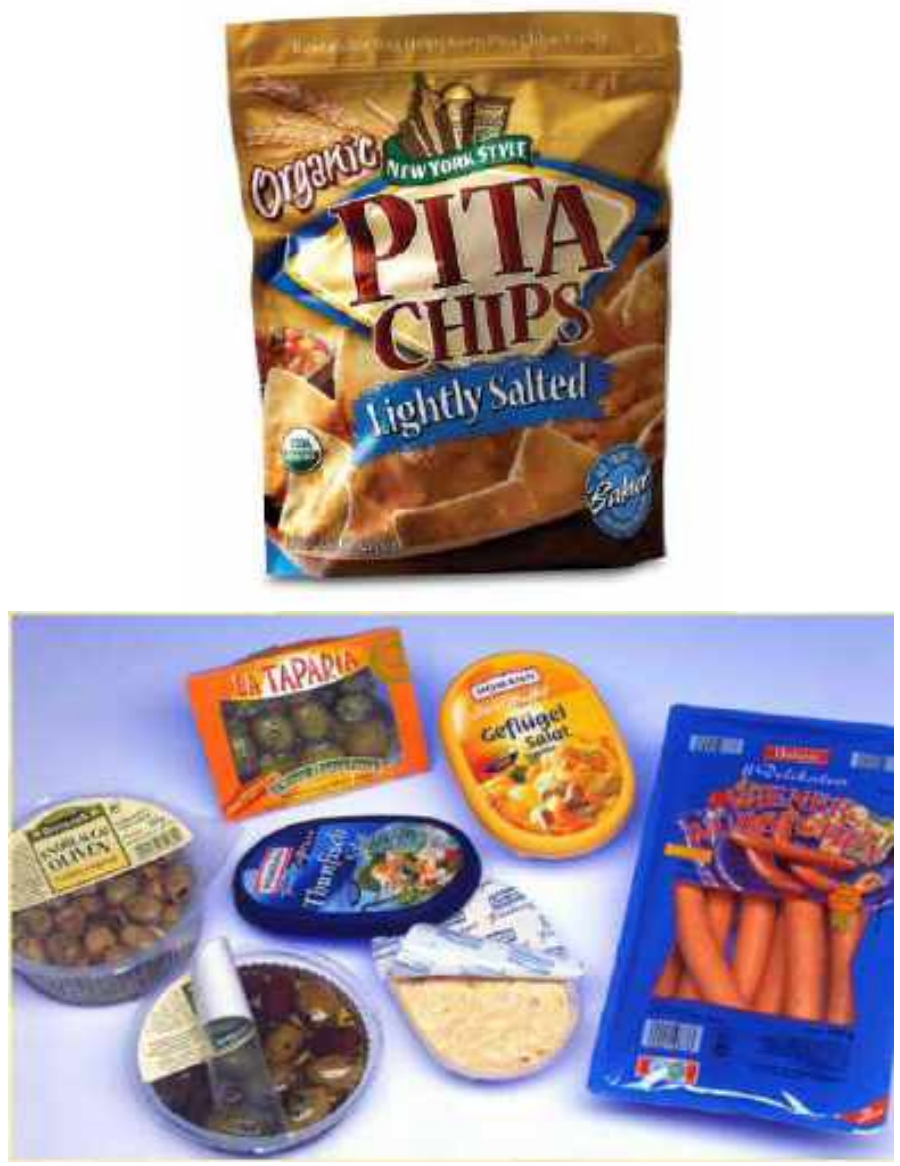
2. Kemasan transport: Kotak Karton Gelombang, Jerigen, Drum dan lain lain
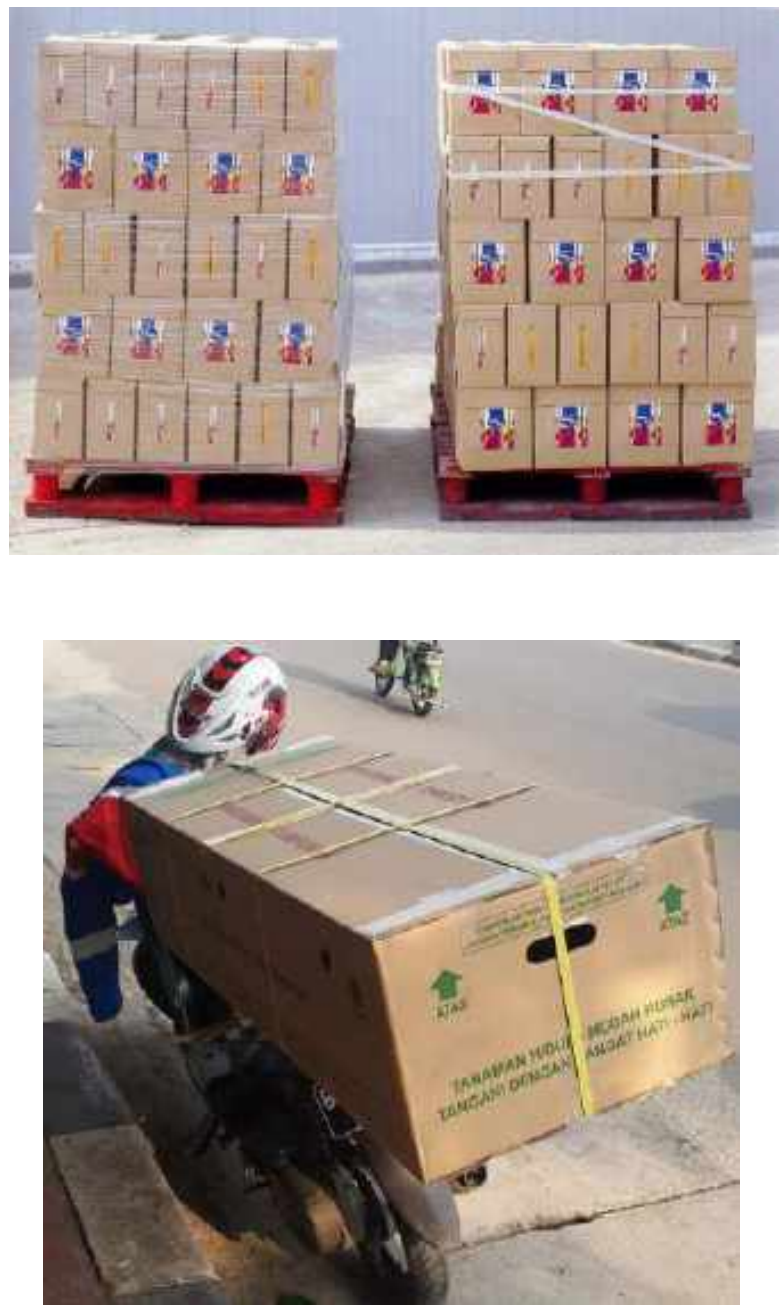
Rangkuman

1. Pengemasan merupakan kegiatan mendesain mendesain dan memproduksi wadah atau pembungkus produk.

2 Fungsi Kemasan

Adapun fungsi kemasan sebagai berikut:
a. Sebagai Wadah
b. Pelindung produk didalamnya
c. Mempertahankan mutu
d. Memperpanjang masa simpan

Pertanyaan Untuk Diskusi

1. Jelaskan Arti Pengemasan

2. Jelaskan Fungsi Kemasan

3. Jelaskan Fungsi Strategi Kemasan

4. Jelaskan Jenis-jenis kemasan 


\section{BAB XV \\ BISNIS MODEL CANVAS}

Tujuan Pembelajaran:

Setelah mempelajari bab ini calon wirausaha diharapkan dapat:

1. Menjelaskan Pengertian Bisnis Canvas

2. Menjelaskan Cara Mengisi Bisnis Canvas

\subsection{Pengertian Bisnis Canvas}

Business Model Canvas atau yang biasa disingkat dengan BMC mulai mendapatkan diindonesia. Sembilan blok business model canvas ciptaan Alexander Osterwalder dari awal dibuat untuk mempermudah pebisnis dalam menulis bussiness plan.Secara singkat, BMC adalah blueprint bisnis startup kita.

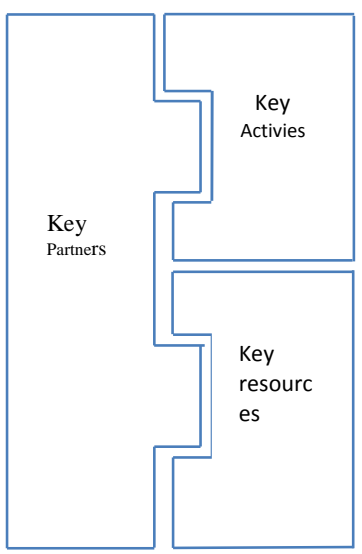

Cost Structure

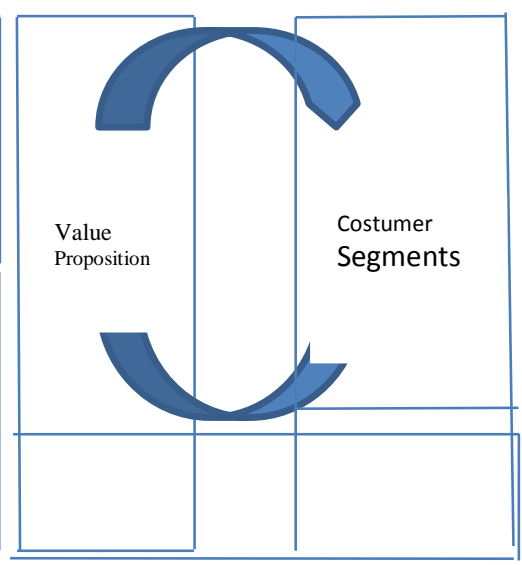

Revenue Stream 


\subsection{Cara Mengisi BMC}

Pada dasarnya, BMC berisi 9 blok yang akan diterangkan lebih lanjut di bawah. Cara Mengisinya sendiri tergantung dengan kebutuhan bisnis kita. Tiap bisnis, bias beda cara Urutan mengisinya. Penulisan business model canvas bisa dimulai :

- Penawaran yang kita punya (offer-led)

- Resources yang kita punya (resource-led)

- Customer yang sudah kita kenal (customer-led)

- Dana yang kita punya (finance-led)

- Atau benar-benar random (multiple-centre)

Untuk mempermudah pemahaman kita terhadap BMC, kami akan menciptakan sebuah Perusahaan virtual yang BMC-nya akan kita buat bersama-sama. Sekaligus untuk Membuktikan bahwa BMC bukan ekslusif untuk teknologi, kita akan membuat perusahaan Fashion. Anggap saja kita mendirikan "Batix Boutique", sebuah perusahaan fashion yang Menawarkan baju batik untuk anak-anak. Melihat jenis bisnisnya, kita akan memberikan Contoh business model canvas dengan metode pengisian offer-led, dimulai dari penawaran Yang kita punya. 
Kanvas Model Bisnis

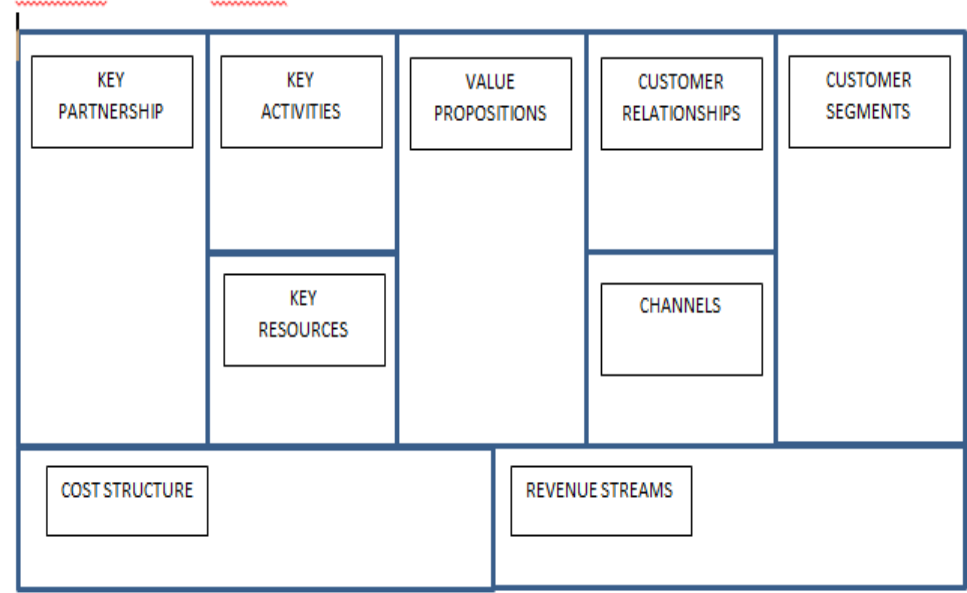

\section{a. Value Proposition}

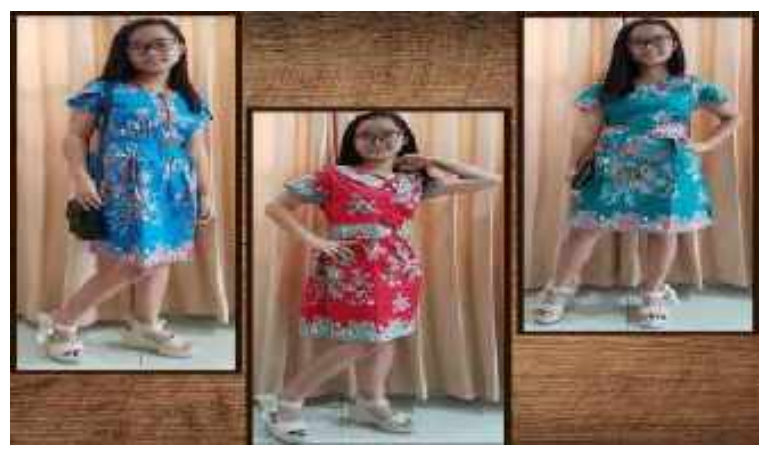

\section{Value Proposition}

Pada dasarnya, value proposition adalah blok pertama yang harus diisi apabila kita menggunakan metode offer-led. Value proposition sendiri merupakan nilai atau value yang kita tawarkan untuk pelanggan. Kelebihan dan keunggulan produk kita disbanding pesaing adalah hal yang harus dituliskan di value proposition. 


\section{Kategori di dalam value proposition}

Lalu, standardnya, value proposition bisa diisi sesuai kategori:

- Newness: produk / jasa yang baru yang belum pernah ditawarkan sebelumnya biasanya banyak ditemukan di dunia teknologi.

- Performance: produk / jasa yang ditawarkan meningkatkan kinerja customer agar menjadi lebih efisien / lebuh efektif.

- Customization: produk / jasa yang ditawarkan berbeda / ada pilihan untuk setiap segmen yang memiliki kebutuhan yang beragam/berbeda

- Getting the Job Done: dengan membeli barang tersebut akan membantu customer menyelesaikan sesuatu.

- Desain (Design) : menawarkan nilai astistik lebih dari sekedar fungsional.

- Status (Brand): merk yang high class memberi social status kepada pembelinya.

- Harga (Price): Menawarkan harga yang bersaing atau sesuai dengan ciri customer segmennya.

- Hemat (Cost Reduction): Produk/Jasa yang ditawarkan membantu customer mengefisienkan biaya pemakaian.

- Meminimalisasi Resiko (Risk Reduction): Menawarkan produk /jasa yang meminimalkan resiko yang ditanggung customer seperti garansi.

- Akses (Accessibility): Mempermudah akses customer terhadap produk/jasa yang ditawarkan. 
- Kenyamanan (Convenience/Usability): Menawarkan produk/jasa yang nyaman dan cenderung mempermudah customer.

\section{Cara salah mengisi Value Proposition}

Cara salah ini sering digunakan untuk pemula, membuat BMC untuk keperluan kuliah dan lomba bisnis. Langsung saja tulis dengan format "Kategori: Keterangan". Contoh, dalam Batix Boutique kita, Value Preposition-nya adalah:

- Design: Menawarkan desain batik khusus yang bisa digunakan untuk anak-anak

- Performance: Baju batik anak-anak Batik Boutique bisa digunakan untuk keperluan formal maupun santai, karena bahannya yang nyaman untuk si kecil.

Cara benar mengisi BMC: Value Preposition

Value Preposotion tetap bisa diisi sesuai kategori, tapi bisa diucapkan sehingga dapat menjadi sales pitch. Format yang dianjurkan:

"(nama produk kita) adalah (apa yang dijual). Tidak seperti (nama pesaing), kami menawarkan (keunggulan produk). Untuk (customer utama), kami punya (keunggulan lagi)". Format ini bisa diucapkan dibawah 30 detik, mudah diingat orang, dan berisi kaidah BMC yang benar. Berikut apabila diterapkan untuk Batik Boutique milik kita: 


\section{Value Preposition}

"Batik Boutique adalah butik yang menjual pakaian batik untuk anak-anak. Tidak seperti produk batik lainnya yang membosankan, kami membuat desain batik yang disukai anakanak. Untuk anak-anak dibawah 12 tahun, batik dari Batik Boutique bisa digunakan untuk acara formal maupun santai."

\section{b. Customer Segments}

Customer segments merupakan penggolaongan orang-orang yang mungkin tertarik dengan value preposition kita

Kategori di dalam Customer Segments:

- Mass Market: Segment pasar luas dengan jenis kebutuhan dan masalah sama

○ Niche Market : Segmen pasar yang spesifik

- Segmented: Segmen pasar yang memiliki kebutuhan berbeda tetapi dalam satu kategori

○ Diversified: Segmen pasar yang memiliki kebutuhan ata masalah yang sangat berbeda

- Multi-Sided Platform: melayani 2 atau lebih pasar yang saling tergantung

Contoh pengisian untuk batix boutique:

Customer Segments

- Prioritas 1 (dan early adopters): Ibu Muda yang mempunyai anak berusia dibawah 12 tahun

- Prioritas 2: toko retail dan eceran anak-anak di Surabaya 
○ Prioritas 3: toko retail dan eceran batik di Surabaya

\section{c. Customer Relationship:}

Customer Relationship merupakan cara-cara yang bisa kita gunaan untuk berkomunkasi dengan customer segmets.

Kategori dalam customer relationship

- Transacional: beli putus saat itu juga

○ Long-term: Ada Sales-Rep yang melayani pelanggan kita

- Personal Assistance: Ada Sales -Rep yang melayani pelanggan

- Self Service: Pelanggan melayani dirinya sendiri, biasanya bisnis retail

- Community: Kita menciptakan komunitas untuk pelanggan

- Co-creation: Kita mengajak pelanggan menciptakan sesuatu bisnis untuk kita

Cara mengisi bisnis model canvas: Customer Relationship Transacional: beli putus saat transaksi

Co-creation: Mengajak Ibu-ibu untuk mengajuka desain batik anak-anak mereka

\section{d. Channels:}

Chanel adalah cara kita menjangkau Customer Kategori didalam Channels

○ Direct: Secara langsung melalui Sales Force, toko sendiri

- Indirect: toko pemilik partner, pusat grosir, agen, reeller 
○ Online: social media, aplikasi messaging, website bisnis, marketplae, forum jual beli

- Awareness: tahap awal mengkonfirmasi ke customer

- Evaluation: cara membantu customer mengevaluasi value propositon yang ditawarkan

- Purchses: cara-cara customer melakukan pembelian

o Delivery: cara menyampaikan value propositon kepada customer

- After Sales: customer support setelah terjadi transaksi

Cara mengisi bisnis model canvas

Channels

Direct: Penjualan langsung ke Ibu rumah tangga, door-to-door Indirect: Menitipkan barang ke pedang retail

Awareness: Menggunakan social media dan internet untuk mempopulerkan batix boutique

\section{e. Key Partners}

$\underline{\text { Key partners }}$ adalah pihak-pihak yang bisa kita ajak kerja sama dengan tujuan:

- Optimization and Economy: motivasi berpartner untuk mengoptimalkan alokasi sumber daya dan aktivitas mengingat sebuah perusahaan tidak perlu memiliki semua sumber daya dan melakukan kegiatannya sendirian

- Reduction of Risk and Uncertainty: mengurangi risiko dan ketidakpastian dalam lingkungan persaingan. 
- Acquisition of particular resources and activities: mengakuisisi perusahaan lain untuk meningkatkan kemampuan kinerja perusahaan.

\section{Kategori di dalam key partners}

- Strategic Alliance between non-competitors: kerjasama dengan perusahaan yang tidak sejenis.

- Coopetition: kerjasama dengan perusahaan kompetitor.

- Joint ventures to develop new business: kerjasama untuk membentuk usaha baru.

- Buyer supplier relationship: hubungan hanya sebagai pembeli dan penjual biasanya terjadi pada motif optimization and economy of scale.

\section{Cara mengisi business model canvas: key partners}

Dalam startup, key partners sangat penting, karena bisa mengurangi biaya dan mempercepat pertumbuhan. Berikut skenario kami untuk Batix Boutique:

Key Partners

- Strategic Alliance: denga perusahaan garmen untuk menjahitkan produk-produk Batix Boutique.

- Supplier Relationship: menitipkan produk Batix Boutique di toko-toko retail Pasar Turi.

\section{f. Cost Structure}


Cost Structure adalah rincian biaya-biaya terbesar yang harus kita keluarkan untuk melakukan key activities dan menghasilkan value proposition.

\section{Kategori di dalam cost structure}

- Cost-driven : sensitive terhadap harga bahan baku

- Value-driven : perusahaan tidak terlalu memikirkan harga produksi/bahan baku karena yang dijual adalah nilai/seni/status/gaya hidup

- Fixed - cost : biaya-biaya tetap yang muncul yang tidak tergantung pada jumlah produksi

- Variable - cost : biaya-biaya yang muncul bervariasi sesuai jumlah yang diproduksi

\section{Cara mengisi business model canvas : cost structure}

Berdasarkan kolom sebelumnya di BMC Batix

Boutique, berikut adalah cost structure-nya :

\section{Cost Structure}

- Cost-driven : biaya keluar tergantung dari harga kain.

- Fixed-cost : Gaji 1 orang fashion designer.

- Variable cost : Biaya jahit tergantung berapa baju yang akan diproduksi. 


\section{Revenue Stream}

Revenue stream dalam BMC akan kita isi dengan berbagai cara untuk menghasilkan keuntungan dari value proposition kita. Bahasa kasarnya : cara kita mendapatkan duit.

\section{Kategori di dalam revenue stream}

- Asset Sale : penjualan produk secara fisik.

- Usage Fee : customer membiayai sesuai lamanya menggunakan produk/jasa.

- Subscription Fees : biaya berlangganan.

- Lending/renting/leasing : biaya peminjaman/pemakaian/penggunaan sementara.

- Licensing : biaya ijin pakai jasa / produk.

Cara mengisi business model canvas : revenue stream Untuk jenis bisnis batix Boutique dan clothing line lainnya, revenue streamnya, yaitu :

Revenue Stream

Asset Sale : penjualan baju batik Boutique. 


\begin{tabular}{|c|c|c|c|c|}
\hline \multirow{2}{*}{ 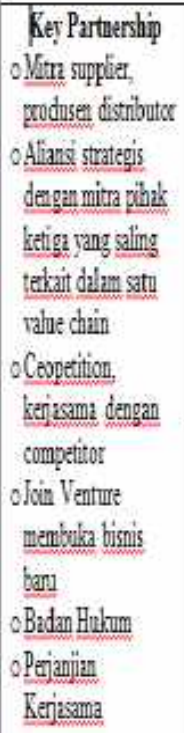 } & 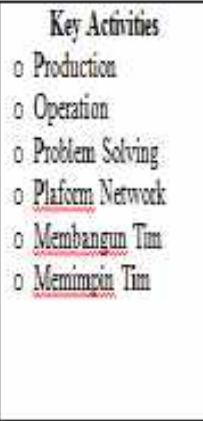 & \multirow{2}{*}{ 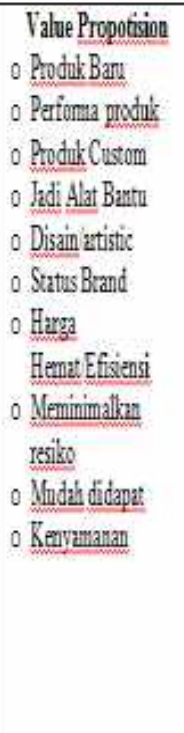 } & 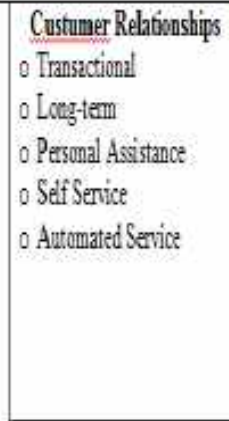 & \multirow[t]{2}{*}{ 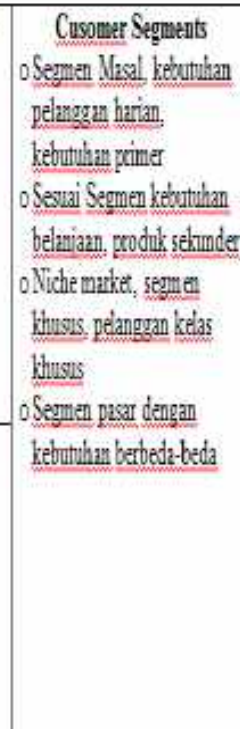 } \\
\hline & 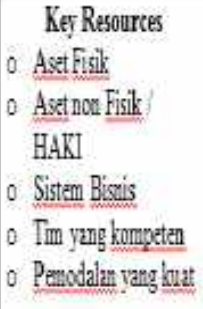 & & 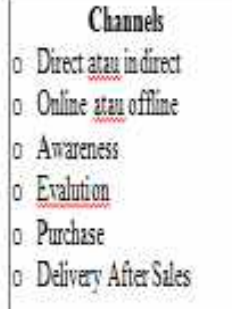 & \\
\hline \multicolumn{3}{|c|}{ Cost Stracture } & \multicolumn{2}{|c|}{ 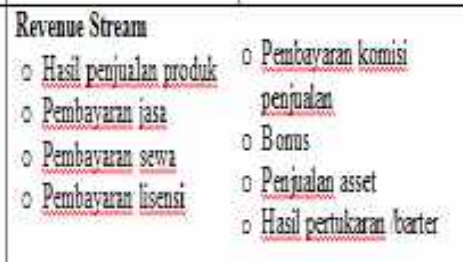 } \\
\hline
\end{tabular}

\section{Rangkuman}

1. Business Model Canvas atau yang biasa disingkat dengan BMC mulai mendapatkan diindonesia. Sembilan blok business model canvas ciptaan Alexander Osterwalder dari awal dibuat untuk mempermudah pebisnis dalam menulis bussiness plan.Secara singkat , BMC adalah blueprint bisnis startup kita. 
Kanvas Model Bisnis

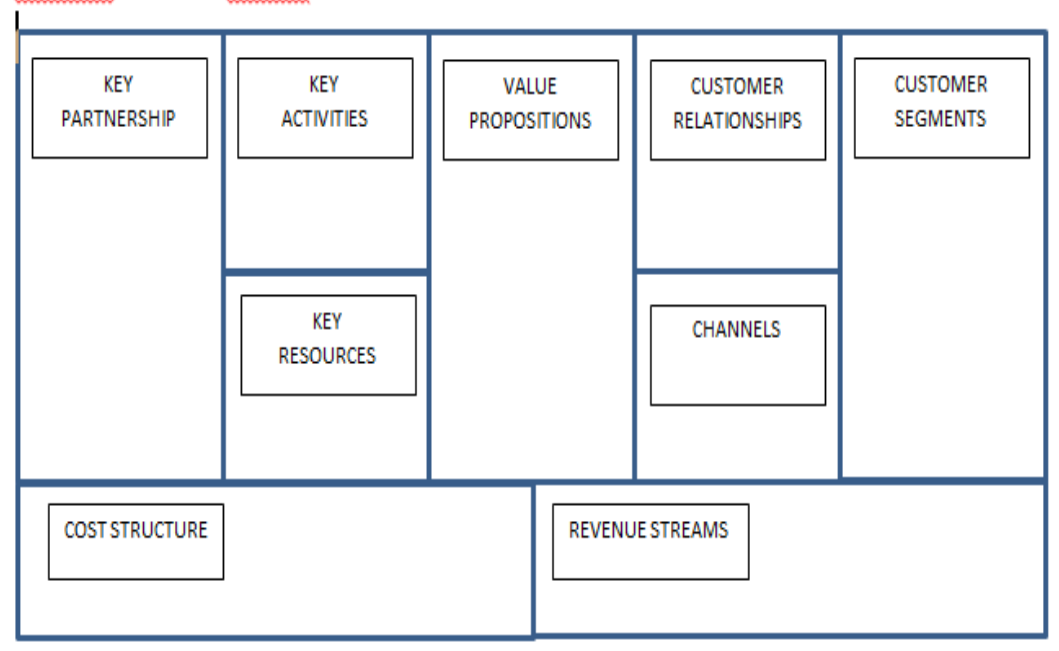

Pertanyaan Untuk Diskusi

1. Jelaskan Pengertian Bisnis Canvas

2. Jelaskan Cara Mengisi Bisnis Canvas 


\section{BAB XVI \\ PERIZINAN USAHA}

Tujuan Pembelajaran:

Setelah mempelajari bab ini calon wirausaha diharapkan dapat:

1. Menjelaskan Pengertian Surat Perizinan Usaha (SITU)

2. Macam-Macam Surat Izin Usaha

\subsection{Surat Izin Usaha Tempat Usaha (SITU)}

SITU merupakan salah satu dari macam-macam surat izin usaha yang merupakan sebuah izin yang diberikan kepada perorangan, perusahaan dan badan usaha untuk memperoleh izin tempat usaha sesuai dengan tata wilayah yang diperlukan dalam rangka penanaman modal.

Biasanya dasar hukum untuk Surat Izin Usaha Tempat Usaha ini dikeluarkan oleh pemerintah dalam bentuk peraturan daerah yang biasanya berlaku hingga tiga tahun dan bias diperpanjang jika masa berlakunya sudah habis. Namun tetap harus memenuhi peraturan yang berlaku. 


\subsection{Macam-macam Surat Izin Usaha}

\section{a. Surat Izin Usaha Industri (SIUI)}

Surat izin ini akan dikeluarkan kepada pengusaha menengah kecil yang ingin memiliki legalitas untuk pemenuhan berkas agar usahanya bisa lebih berkembang di industri. Syaratannya pengusaha kecil ini telah memiliki modal 5-200 juta. Syarat untuk mendapatkan surat izin ini adalah dengan mengajukannya ke kantor Pelayanan Perizinan Terpadu Daerah Tingkat II Kabupaten atau Kota. Jika usahanya telah berkembang maka bisa mengajukan ke pelayanan perizinan terpadu Tingkat II Provinsi atau BKPM.

\section{b. Surat Izin Usaha Perdagangan (SIUP)}

Fungsi dari surat izin SIUP adalah agar perusahaan, koperasi, persekutuan maupun perusahaan perseorangan dapat melakukan kegiatan usaha perdagangan wajib memperoleh SIUP yang di terbitkan berdasarkan domisili perusahaan dan berlaku diseluruh wilayah Republik Indonesia. SIUP ada 3 jenis :

- SIUP Kecil yang di keluarkan untuk perusahaan yang memiliki modal disetor dan kekayaan bersih dibawah Rp.200 juta di luar tanah dan bangunan.

- SIUP Menengah yang dikeluarkan bagi perusahaan yang memiliki modal disetor dan kekayaan bersih Rp.200 juta s/d Rp.500 juta di luar tanah dan bangunan. 
- SIUP Besar yang dikeluarkan perusahaan memiliki modal disetor dan kekayaan bersih diatas Rp.500 juta di luar tanah dan bangunan.

\section{Badan POM}

Badan Pengawas Obat dan Makanan atau disingkat Badan BPOM adalah sebuah lembaga di Indonesia yang bertugas mengawasi peredaran obat-obatan dan makanan di Indonesia. PP No. 69 tahun 1999 tentang Label dan iklan Pangan. Institusi permerintah yang bertanggung jawab terhadap peredaran produk pangan olahan diseluruh Indonesia.

Badan POM berfungsi, antara lain:

1. Pengaturan, regulasi, dan standarisasi

2. Lisensi dan sertifikasi industry dibidang farmasi berdasarkan "Cara-cara Produksi yang baik"

3. Evaluasi produk sebelum diizinkan beredar

4. Post marketing vigilance termasuk sampling dan pengujian laboraturium, pemeriksaan sarana produksi dan distribusi,penyidikan dan penegakan hokum.

5. Pre-audit dan pasca-audit ikln dan promosi produk

6. Riset terhadap pelaksanaan kebijakan pengawasan obat dan makanan.

7. Komunikasi, informasi dan edukasi public termasuk peringatan publik. 


\section{Pangan Industri Rumah Tangga (PIRT)}

PIRT adalah jaminan dan pemerintah kabupaten/kota atas sebuaqh produk yang memberikan jaminan pada masyarakat bahwa produk tersebut aman untuk dikonsumsi oleh masyarakat

- Sertifikasi diberikan kepada produsen makanan/minuman industry rumah tangga dengan modal kurang dari Rp. 50 juta, untuk modal lebih besar dari Rp. 50 juta ijin diajukan ke Balai Besar POM.

PIRT adalah izin untuk industri skala rumahan. Izin PIRT (Pangan Industri Rumah Tangga) adalah sebuah keharusan jika kita memiliki usaha makanan skala kecil.. Tidak semua produk makanan dari sector skala kecil bias mendapatkan izin PIRT. Sertifikat PIRT tidak berlaku untuk:

- Susu dan hasil olahannya

- Daging, ikan, unggas, dan olahannya yang memerlukan

- Penyimpanan beku

- Pangan kaleng berasam rendah

- Makanan bayi

- Minuman berakohol

- Air dalam kemasan pangan lain yang memenuhi SNI 
- Pangan olahan lain yang ditetapkan oleh BPOM Dimana pangan yang disebutkan diatas harus didaftarkan lewat BPOM

\section{E. MD}

Nomor MD diberikan kepada produsen dan makanan dan minuman dalam negeri yang bermodal besar diperkirakan mampu untuk mengikuti persyaratan keamanan pangan yang telah ditetapkan oleh pemerintah . MD bersifat lokal adalah industri skala besar yang memproduksi produk mereka sendiri. Contohnya : Produk Indomie dari Indofood pasti memiliki kode MD. Kode MD untuk satu produk juga dapat berbeda tergantung lokasi pabrik yang melakukan produksi.

Nomor ML, diberikan untuk produk makanan dan minuman olahan yang berasal dari produk impor, berupa kemasan langsung maupunn dikemas ulang. ML adalah izin untuk industri besar dan bersifat import. Produk makanan dan minuman yang di impor masuk ke Indonesia pasti memiliki kode ML.

Contohnya : Produk-produk Nestle, baik yang di impor langsung maupun dikemas di Indonesia.

Nomor SP adalah sertifikat penyuluhan, merupakan nomor pendaftaran yang diberikan kepada pengusaha kecil dan modal terbatas dan pengaswan langsung dilakukan oleh Dinas Pengawasan Kesehatan/Kodya, dalam bentuk penyuluhan. Para pelaku usaha dengan SP biasanya mengikuti penyuluhan 
yang diberikan Dinas Kesehatan Kabupaten. Pengawasan juga dilakukan melalui sidak-sidak untuk memastikan proses produksi sesuai standar. Misalnya memastikan bahan yang digunakan aman dan tidak berbahaya di konsumsi.

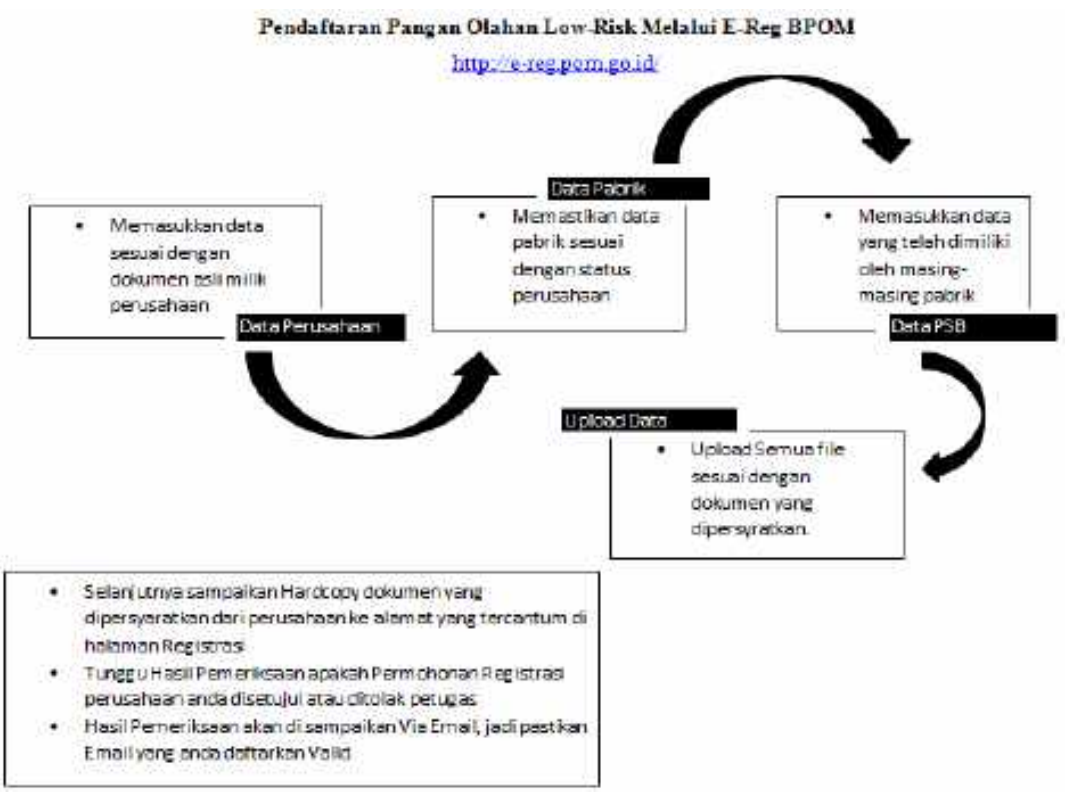




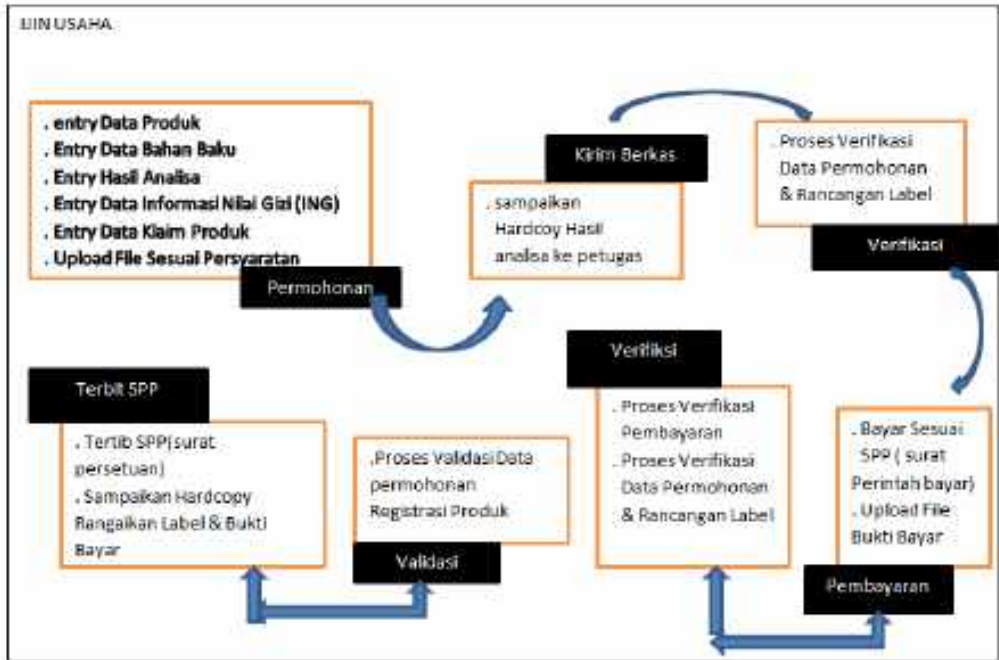

\section{F. Prosedur Sertifikasi Halal MUI}

Bagi perusahaan yag ingin memperoleh sertifikat Halal LPPOM MUI, baik Industri Pengolahan (Pangan, obat, kosmetika), Rumah Potong Hewan (RPH), dan restoran/katering/dapur, harus melakukan pendaftaran sertifikasi halal dan memenuhi persyaratan sertifikasi halal. Berikut ini adalah tahapan yang dilewati perusahaan yang akan mendaftar proses sertifikasi halal sebagai berikut:

1. Memahami persyaratan sertifikasi halal dan mengikuti pelatihan $\mathrm{SIH}$

2. Menerapkan sistem Jaminan Halal (SJH)

3. Menyiapkan dokumen sertifikasi halal

4. Melakukan pendaftaran sertifikasi halal (upload data)

5. Melakukan monitoring pre audit dan pembayaran akad sertifikasi

6 Pelakasanaan Audit

7. Melakukan monitoring pasca audit

8. Memperoleh Sertifikat Halal 


\section{Logo Sertifit Halal MUI}

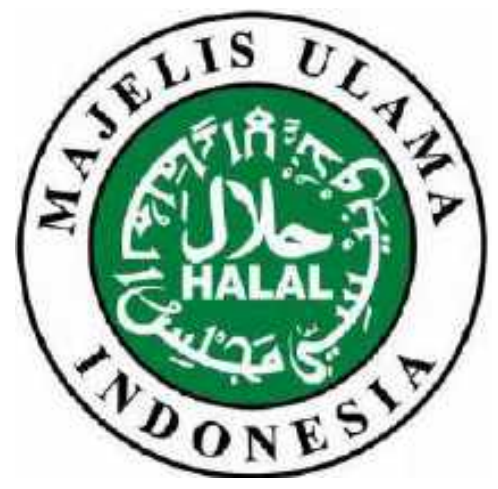

UINUS AHA

Secara ummmprosectur sertifil:a si halal cnline adalah seb agai berikut:

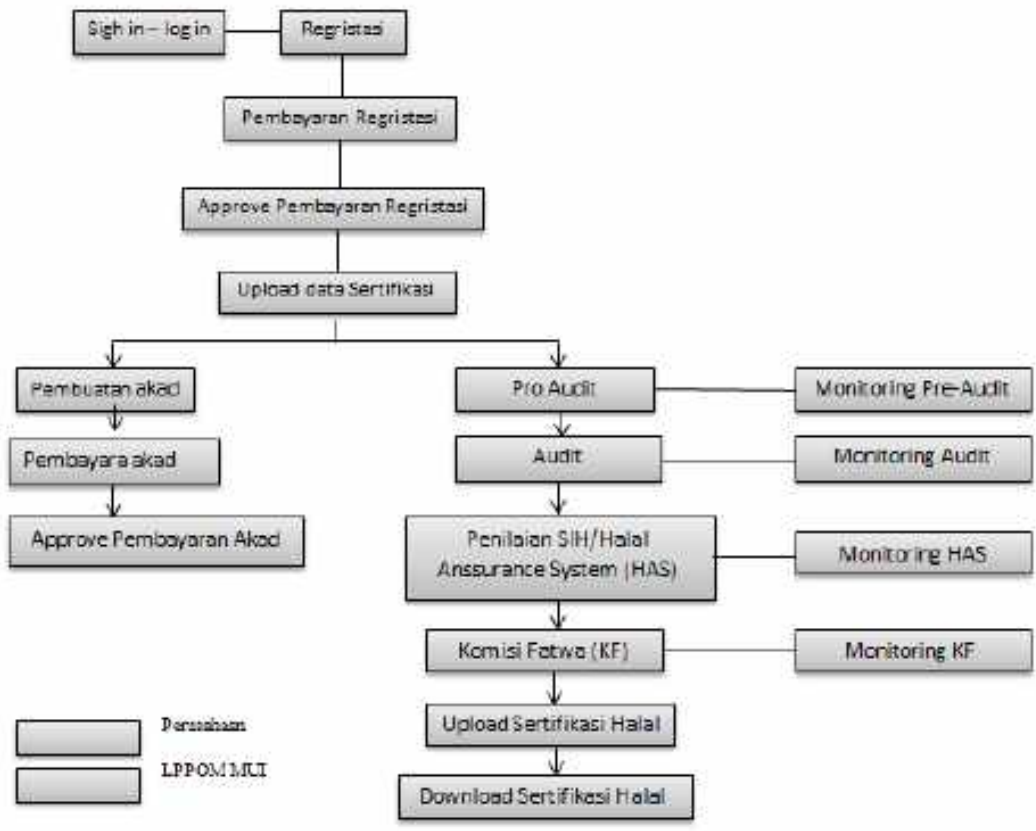

Rangkuman 
1. SITU merupakan salah satu dari macam-macam surat izin usaha yang merupakan sebuah izin yang diberikan kepada perorangan, perusahaan dan badan usaha untuk memperoleh izin tempat usaha sesuai dengan tata wilayah yang diperlukan dalam rangka penanaman modal.

2. Macam-macam Surat Izin Usaha
a. Surat Izin Usaha Industri (SIUI)
b. Surat Izin Usaha Perdagangan
c. BPOM
d. MD
e. PIRT

3. Pertanyaan Untuk Diskusi

1. Jelaskan PengertianSurat Perizinan Usaha (SITU)

2. Jelaskan macam-Macam Surat Izin Usaha 


\section{BAB XVII \\ PROPOSAL BISNIS}

Tujuan Pembelajaran:

Setelah mempelajari bab ini calon wirausaha diharapkan dapat:

1. Menjelaskan pengertian proposal bisnis

2. Menjelaskan tujuan proposal bisnis

3. Menjelaskan Keuntungan proposal bisnis

4. Komoponen Proposal Yang Baik

\subsection{Pengertian Proposal Bisnis}

Proposal berasal dari kata to propose yang artinya mengajukan. Istilah proposal berarti ajuan penawaran beberapa gagasan, ide dan pemikiran kepada pihak lain untuk mendapat dukungan, persetujuan, izin dan sebagainya. Sebuah Proposal Bisnis haruslah mengandug tiga syarat utama, yaitu mempunyai tujuan, terncana dan sistematis.

\subsection{Tujuan Proposal Bisnis}

Adapun tujuan proposal bisnis yakni:

a. Memberikan gagasan dalam menjalankan usaha Anda, agar tetap berada dalam alur yang diinginkan.

b. Dapat digunakan untuk meyakinkan pihak-pihak yang akan memberikan dukungan pendanaan 


\subsection{Keuntungan proposal Bisnis}
a. Sebagai gambaran dari usaha yang dijalankan
b. Mempunyai perencanaan strategi dan logistik
c. Mempunyai alat ukur dalam melaksanakan pekerjaan
d. Mempunyai sasaran tertulis dalam kerangka acuan yang dapat digunakan dari waktu ke waktu
e. Sebagai alat penjualan dan prospektus, untuk mencari modal atau pinjaman.

\subsection{Komponen Proposal Bisnis yang Baik}

Adapun komponen proposal bisnis sebagai berikut:

1. Ringkasan Eksekutif

2. Deskripsi Bisnis

3. Strategi Pemasaran

4. Analisis Persaingan

5. Rencana Desain dan Pengembangan

6. Rencana Operasi dan Manajemen

7. Analisis Rencana Keuangan 


\section{Contoh Proposal}

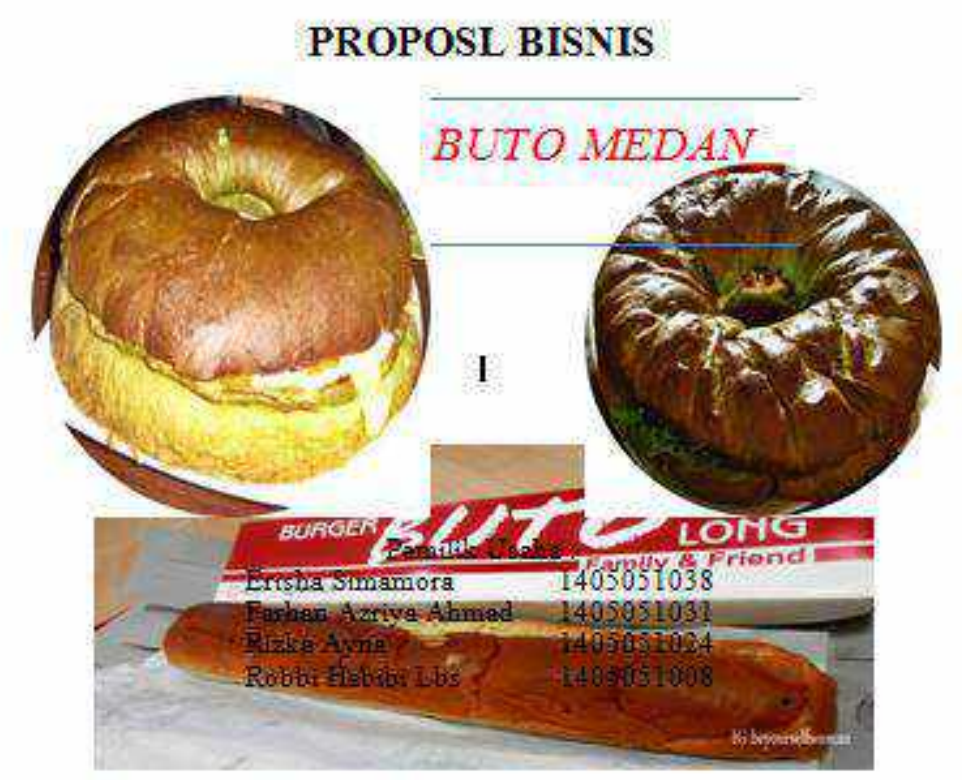

I. Karya Wis ata Komp Villa PrimaIndahNo,22 Blok B medan johor

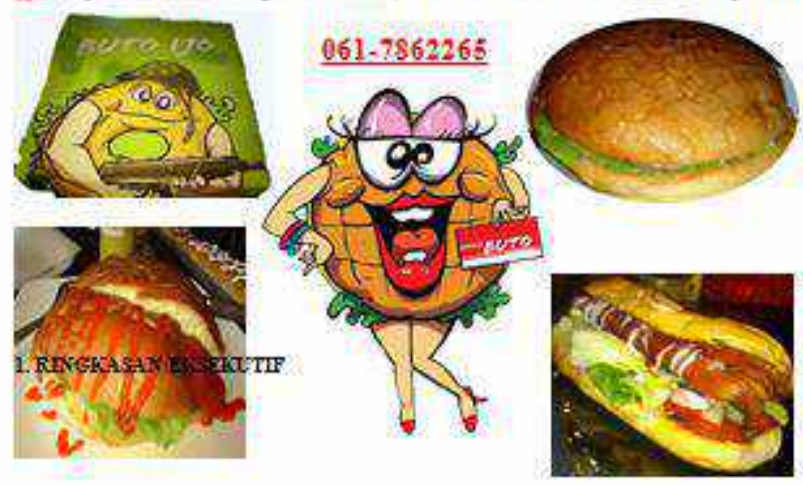




\section{PENDAHULUAN}

Warung Buto Medan adalah dari kata yang kami rangkai agar menjadi suatu keunikan buat konsumen dan menjadi kesan yang positif bagi pelanggan. Pada dasarnya remaja dalam memilih makanan, mereka akan melihat bentuk makanan terlebih dahulu dimatanya tanpa mengetahui rasanya terlebih dahulu. Dalam pemenuhan makanan yang sehat, bergizi, dan bervitamin, maupun kebutuhan nutrisi yang penting lainnya banyak remaja yang tertarik, karena rasa di dalamnya sangat bagus bagi. Hal inilah yang membuat kami tertarik untuk menjadikan bahan makanan yang sehat,bergizi dan bernutrisi akan menjadi lebih menarik dan diminati bagi banyak ramaja. Bagi ramaja, mereka tidak begitu memikirkan kandungan gizi dan nutrisi yang terkandung didalam makanan yang akan mereka beli, tetapi dengan bentuk yang unik dan menarik yang akan mereka gemari.

Proposal usaha Warung Buto Medan ini sangat cocok dan potensial, bila kita mendirikan sebuah usaha jualan makanan besar, dimana dari segi rasa memenuhi konsumen yaitu beragam rasa, enak, dari segi gizi sesuai dengan apa yang diinginkan oleh konsumen karena mengandung vitamin,gizi,nutrisi, dll. Dari segi harga terbilang mudah dijangkau oleh lapisan masyarakat.

Saat ini sebagian besar masyarakat mengenal burger dan hotdog,hanya sebatas di panggang dengan ukuran standart 
dengan berbagai cara membuat maupun perasa lainnya. Dengan bentuk yang besar dan terlalu unik membuat bahan makanan yang sangat lembut mudah hancur. Hal ini menyebabkan mengurangnya bahan makanan dan kelambatanproses pembentukan makanan dan harus diganti. Selain itu Warung Buto Medan dapat dijadikan sumber jajanan sehat ataupun makanan alternative untuk mengenyangkan perut.

\subsection{Tujuan}

Dengan adanya ide usaha yang terlintas begitu saja maka kami ingin menciptakan sebuah warung yang menjual makanan sehat, bervitamin, bernutrisi dan bentuknya yang sangat besar yang banyak di gemari oleh semua kalangan terutama kalangan anak ramaja. Maka dari itu kami ingin membuat sebuahusaha kecil-kecilan yang bermodalkan kecil.namun mudah-mudahan bisa menjadi sebuah perusahaan besar yang bergerak dibidang makanan sehat pertama dan yang utama. 


\subsection{Visi \& Misi}

Usaha Warung Buto Medan ini juga memiliki visi untuk memperlancar usahanya, diantaranya :

$>$ Menjadikan Warung Buto Medan menjadi perusahaan yang dapat menciptakan berbagai makanan yang sehat,bervitamin, bergizi, dan bernutrisi.

$>$ Dapat disukai oleh semua kalangan masyarakat pada umumnya terutama remaja.

$>$ Menjadi Perusahaan makanan sehat terkemuka yang berkualitas dengan citarasa tinggi dan sehat di tingkat Nasional.

$>$ Dapat menciptakan lapangan pekerjaan baru.

Misi dari kami untuk kedepan :

$>$ Menjadikan Warung Buto menjadi terkenal dan tersebar di seluruh kalangan.

> Peningkatan kapasitas produksi.

> Peningkatan efisiensi dan efektivitas produksi.

$>$ Peningkatan kegiatan pemasaran produksi.

$>$ Dapat mengatasi pengangguran.

\subsection{Kunci Kesuksesan}

Kunci kesuksesan dari perusahaan kami adalah :

$>$ Rasa yang khas dan bentuk yang unik pada produk itu sendiri. 
$>$ Bentuk yang dapat menarik minat remaja

$>$ Ketepatan waktu dan jumlah produksi.

\subsection{Resiko yang Dihadapi}

Masalah dalam usaha "Warung Buto Medan" ini adalah bahan baku. Dimana bahan baku yang digunakan adalah bahan baku yang berkualitas tinggi agar dapat memuaskan pelanggan dan agar pelanggan selalu merasa ingin datang kembali untuk membeli produk kami lagi. Untuk memperoleh bahan baku yang memenuhi kualitas, kami akan menyeleksi kandungan yang benar-benar bermanfaat dan kami akan bekerjasama dengan beberapa swalayan untuk memasok semua kebutuhan kami tersebut menjadi berkualitas. Dengan menggunakan bahan-bahan dengan mutu tinggi maka harga yang dikenakan untuk 1 jenis makanan di warung buto medan tidak begitu mahal juga tidak murah, hal itu bertujuan menutupi pengeluaran untuk membeli bahan baku. Jika kami mengganti bahan baku dengan kualitas rendah, maka rasa dan tekstur yang dihasilkan akan menurun, dan mungkin dengan kondisi tersebut para konsumen akan mengurangi konsumsi di warung buto medan. Maka produsen akan mengambil jalan tengah dengan mengganti bahan baku dengan harga lebih murah dengan kualitas yang bersaing dengan bahan baku sebelumnya. 


\section{GAMBARAN UMUM PERUSAHAAN}

\subsection{Gambaran Umum Perusahaan}

Nama perusahaan

Alamat

Telepon

Bentuk Usaha

Aspek Legal

Bidang / Sektor Usaha

Pasar
: Warung Buto Medan

: Jl.Karya Wisata Komp Villa Prima Indah No.22 Blok B Medan Johor

: 0617862265

: Kepemilikan Kelompok

: KTP/SIM/KTM

: Home industri / Industri

Makanan ringan

: Dalam Negeri

\section{RINGKASAN PRODUK}

Warung Buto Medan memproduksi macam produk olahan dari berbagai bahan makanan . Adapun produk yang diproduksi secara rutin adalah :

\begin{tabular}{|c|c|c|c|c|}
\hline No & Nama Barang & Kode & Harga/bks & Gambar \\
\hline 1. & Burger Buto ljo & WBM 001 & Rp. 60.000 \\
\hline 2. & Hotdog Buto & WBM 002 & Rp. 55.000 \\
\hline
\end{tabular}


Selain barang produksi regular,kami juga berusaha menyediakan bahan makanan yang dapat di rekreasikan sendiri oleh pemesan agar dapat membuat burger dan hotdog sesuai kemauannya.

\subsection{Perbandingan Kompetitif}

Produk kami memiliki keunggulan dalam hal kualitas produk, yang merupakan hasil murni dari alam dengan kandungan nutrisi, gizi, dan vitamin yang baik bagi kesehatan dan merupakan ciri khas dari produk kami, yang tidak dimiliki oleh perusahaan lainnya.

Selain itu proses pengemasan yang dan terjamin dari segi kesehatan untuk konsumen kami, oleh karena itu produk kami dijamin memiliki prospek yang cerah dan memiliki keunggulan kompetitif di pasaran.

\section{4 .ASPEK PEMASARAN}

\subsection{Permintaan Pasar}

Permintaan pasar akan produk makanan ringan ini belum terdeskripsikan, hal ini disebabkan, produk kami merupakan produk yang penyajiannya belum pernah ada di kota medan. Dari hasil pemantauan kami terhadap produk yang sejenis yang sistem penyajiannya tidak sama memiliki kecenderungan permintaan yang terus meningkat. Hal ini disebabkan oleh semakin meningkatnya kebutuhan burger yang instant di kotaMedan yang menginginkan makanan ringan dan 
segar disajikan secara cepat dan enak tanpa harus repot berbelanja di supermarket atau di pasar. Melihat peluang dari permintaan yang semakin meningkat, maka kami berinisiatif untuk mencoba memasuki pasar tersebut dengan memproduksi hidangan segar dan sehat berbasis buah maupun sayuran dengan sajian yang menarik yang mampu meningkatkan nafsu makan akan bahan-bahan tersebut.

Di awal bisnis kamiakan memulai dengan satu tempat. Apabila respon dari konsumen baik terhadap produk bisnis ini maka akan dibuka di tempat-tempat lain dan tentunya akan dilakukan di kota lain.

Dan selain itu kamiakan membuat aneka macam makanan di warung buto medan dengan kombinasi makanan lainnya.

\subsection{Penawaran pasar}

Kegiatan yang akan dilakukan untuk memperkenalkan "Warung Buto Medan" kepada masyarakat adalah dengan cara promosi.

Dalam usaha ini pemilik mempromosikan usahanya dengan cara memberikan sample terlebih dahulu agar konsumen tertarik dan mencoba menawarkan kepada anaknya Berhubung pemilik merupakan mahasiswa sehingga target penjualannya adalah warga sekitar kampus. 


\subsection{Peluang Pasar}

Dari gambaran peluang permintaan yang didapatkan, terdapat penawaran produk sebesar $100 \%$ dari total permintaan pasar yang ada, maka dapat ditarik kesimpulan adanya peluang yang kami miliki untuk jenis produk ini adalah $100 \%$.

\begin{tabular}{|c|c|c|c|}
\hline Produk & Permintaan & Penawaran & Peluang \\
\hline Burger Buto & $100 \%$ & $100 \%$ & $100 \%$ \\
\hline Hotdog Buto & $100 \%$ & $100 \%$ & $100 \%$ \\
\hline
\end{tabular}

\subsection{Strategi Penjualan}

Warung Buto Medan memiliki strategi utama dalam kegiatannya :

> Membuat iklan "Warung Buto Medan" di majalah-majalah dan surat kabar yang diterbitkan di kota Medan.

> Memberikan harga sepesial selama promo.

> Selalu menjaga kualitas rasa dan tekstur dari setiap jenis makanan dengan menggunakan bahan-bahan yang berkualitas

> Selalu mendengarkan kritik dan saran yang diajukan oleh para konsumen agar warung buto medan dapat berkembang dan membuka cabang serta menjadi makanan yang baik bagi konsumen

$>$ Menetapkan harga yang bersaing dengan tetap memperhatikan bahan baku yang digunakan. 
Berikut ini adalah proporsi rencana penjualan :

\begin{tabular}{|c|c|c|c|}
\hline Produk & Lokasi & Pesanan Perhari & $\begin{array}{c}\text { Pesanan } \\
\text { Perbulan }\end{array}$ \\
\hline $\begin{array}{c}\text { Burger } \\
\text { Buto ljo }\end{array}$ & $\begin{array}{l}\text { Alamat } \\
\text { Rumah }\end{array}$ & 13 Porsi & 390 Porsi \\
\hline $\begin{array}{c}\text { Hotdog } \\
\text { Buto }\end{array}$ & $\begin{array}{c}\text { Alamat } \\
\text { Rumah }\end{array}$ & 12 Porsi & 360 Porsi \\
\hline Total & & & 750 Porsi \\
\hline
\end{tabular}

\begin{tabular}{|c|c|c|c|c|c|c|}
\hline No. & Item & Kode & Distributor & Lainnya & Harga & Jumlah \\
\hline $\mathbf{1 .}$ & Burger Buto ljo & $\begin{array}{c}\text { WBM } \\
001\end{array}$ & 13 Porsi & & Rp. 60.000 & 780.000 \\
\hline $\mathbf{2 .}$ & Hotdog Buto & 002 & 12 Porsi & & Rp.55.000 & 660.000 \\
& \multicolumn{7}{|c|}{ Total } & & & & RB. 1.440.000 \\
\hline
\end{tabular}

\subsection{Strategi Pemasaran}

Target pasar kami yang utama ialah untuk memenuhi permintaan dari distributor - distributor besar dan eceran yang berlokasi di kota Medan dan sekitarnya, dan juga pemenuhan pesanan yang datang langsung kepada kami untuk produk produk dari perusahaan kami tersebut.

Kami membagi segmen pasar menjadi beberapa kelompok yaitu :

Kalangan rumah tangga yang membutuhkan untuk cemilan rumahan dan perayaan hari istimewa atau hajatan. 
> Kalangan Pengusaha yang membutuhkan untuk acara perkantoran seperti syukuran, penerimaan tamu atau relasi, dan lain-lain.

> Kalangan restoran maupun jajanan kaki lima untuk hidangan pembuka

\subsection{Strategi Segmentasi Pasar}

Sasaran utama dari segmen perusahaa ialah rumah tangga yang biasanya menyediakan hidangan cemilan yang mengenyangkan, strategi utama ialah dengan memasarkan produk kami melalui distributor di Medan. Selain itu kami juga memberikan service lebih dengan memberikan layanan delivery service untuk tempat-tempat yang terjangkau.

Untuk segmen umum kami biasanya memasok produkproduk kami ke tempat-tempat yang mudah di jangkau oleh konsumen tersebut. Selain itu kami juga memasarkan produk kami ketempat yang bersedia menjual produk kami ke restorant kaki lima yang banyak terdapat di jalan gagak hitam dan juga tempat penjualan lainnya.

Untuk segmen perkantoran biasanya kami memasarkan melalui sistem pemesanan .Hal ini cukup efektif, dikarenakan pembayaran yang dilakukan langsung secara tunai, berbeda dengan retail-retail lainnya. 


\subsection{Strategi Penetapan Harga}

Harga yang akan kami tawarkan akan disesuaikan dengan jenis pesananyang ada di daftar menu Warung Buto Medan. Dan tentunya akan terjangkau bagi para konsumen. Sehingga konsumen dapat mengkonsumsinya tanpa harus mengocek saku dalam-dalam.harga yang akan kami tawarkan hanya berkisar antara Rp 55.000 sampai Rp 60.000 dan dapat dibagi 6 orang/porsi jadi sekitar Rp 9.000 sampai Rp 10.000 saja.

Dalam penetapan harga dari produk kami sangat tergantung pada harga bahan baku, yang memiliki pengaruh terhadap harga jual produk kami. Untuk penetapan harga retail, standar harga yang kami berlakukan ditambah proporsi keuntungan dari retailer yang dalam hal komisi penjualan tarif yang biasanya di berlakukan ialah $30 \%$ dari total penjualan.

Untuk produk yang di jual kepada konsumen rumah tangga langsung, kami menetapkan harga sesuai dengan pasar yang ada.Khusus untuk pembelian/pemesanan dalam jumlah besar, perusahaan menetapkan harga yang lebih fleksibel ratarata dengan discount $10 \%$ setelah pembelian 50 kotak jajanan dari warung buto medan.

\subsection{Distribusi}

Proses pendistribusian yang dilakukan, ialah melalui distribusi langsung dari perusahaan kami ke tempat-tempat tujuan pemasaran. Dan juga proses antar langsung kerumah 
pesanan atau delivery services untuk pemesanan lokal Medan dengan syarat tertentu.

\subsection{Strategi Promosi}

Kami akan melakukan strategi Promosi, dikarenakan promosi merupakan hal yang sangat penting dalam usaha ini, oleh karena itu kami telah menganggarkan Rp. 200.000 / bulan untuk biaya promosi, yang berupa :

- Biaya Promosi Brosur

Rp 100.000,00

- Biaya pamphlet warung

Rp. $100.000,00$

Selain itukamipun mengikuti kegiatan berupa pameranpameran seperti yang dilakukan sebelumnya melalui kerjasama dengan pihak yang tertarik. Untuk kedepan kami akan mencoba untuk mempromosikan produk kami melalui website dan iklan di koran.

\section{ASPEK PRODUKSI}

Aspek produksi merupakan faktor yang sangat penting dalam keberhasilan kami, yaitu bagaimana perusahaan dapat memproduksi dengan waktu yang tepat dalam memenuhi keinginan pemesanan, peningkatan kualitas dan juga efisiensi produksi yang akan menentukan biaya pokok.

Berdasarkan perencanaan penjualan yang telah dilakukan maka produksi akan dimulai dengan kapasitas produksi sebesar 750 Porsi perbulan, jumlah tersebut adalah jumlah maksimal yang dapat diproduksi oleh perusahaan. 
Guna mendukung dari rencana pengembangan produksi maka ada beberapa hal yang harus dipersiapkan, yaitu tata cara pemenuhan bahan baku

\subsection{Pemenuhan Bahan Baku}

Bahan baku yang diperlukan cukup memadai, hal ini dikarenakan bahan baku yang dipakai untuk proses produksi dapat dijumpai dimanapun. Namun untuk pemenuhan bahan baku sendiri, kami telah mensurvey apa yang kami butuhkan.

Untuk bahan baku proses produksi itu sendiri, sebagai produksi pokok perusahaan ini diperlukan bahan-bahan seperti keju, roti ukuran besar, daging berkualitas, dan lain-lain. Dalam Tabel Berikut akan diuraikan kebutuhan bahan baku per produk. Dengan asumsi harga bahan baku tetap dan produksi tetap untuk 1hari pemakaian. yaitu :

Kebutuhan Bahan Baku Perhari

\begin{tabular}{|c|c|c|l|}
\hline Bahan Baku & Kebutuhan & Harga & Total \\
\hline Keju & $\begin{array}{c}4 \text { bungkus/ } \\
1 / 2 \text { lusin }\end{array}$ & $\begin{array}{c}\text { @ Rp. } \\
11.000\end{array}$ & Rp. 44.000 \\
\hline $\begin{array}{c}\text { Roti Bulat } \\
\text { Besar }\end{array}$ & 13 bungkus & @ Rp. 8.000 & Rp. 104.000 \\
\hline $\begin{array}{c}\text { Roti Hotdog } \\
\text { Besar }\end{array}$ & 12 bungkus & @ Rp. 6.000 & Rp. 72.000 \\
\hline Abon & 3 bungkus & $\begin{array}{c}\text { @ Rp. } \\
10.000\end{array}$ & Rp. 30.000 \\
\hline
\end{tabular}




\begin{tabular}{|c|c|c|c|}
\hline Nuget & 3 bungkus & $\begin{array}{l}\text { @ Rp. } \\
25.000\end{array}$ & Rp. 75.000 \\
\hline Timun & $2 \mathrm{Kg}$ & @ Rp. 8.000 & Rp. 16.000 \\
\hline Tomat & $2 \mathrm{Kg}$ & $\begin{array}{l}@ \mathrm{Rp} . \\
12.000\end{array}$ & Rp. 24.000 \\
\hline Daging & 3 bungkus & $\begin{array}{l}@ \mathrm{Rp} . \\
20.000\end{array}$ & Rp. 60.000 \\
\hline Selada & $1 \mathrm{Kg}$ & @ Rp. 8.000 & Rp. 8.000 \\
\hline Telur & 5 papan & $\begin{array}{l}\text { @ Rp. } \\
40.000\end{array}$ & Rp. 200.000 \\
\hline Sosis Jumbo & 2 bungkus & $\begin{array}{l}@ \mathrm{Rp} . \\
30.000\end{array}$ & Rp. 250.000 \\
\hline Saus Cabai & 3 Botol & $\begin{array}{l}\text { @ Rp. } \\
10.000\end{array}$ & Rp. 30.000 \\
\hline Saus Tomat & 3 Botol & $\begin{array}{l}@ \mathrm{Rp} . \\
10.000\end{array}$ & Rp. 30.000 \\
\hline Mayones & 3 Botol & $\begin{array}{l}@ \mathrm{Rp} . \\
15.000\end{array}$ & Rp. 45.000 \\
\hline Garam & 2 Bungkus & @ Rp. 3.000 & Rp. 6.000 \\
\hline Margarin & $2 \mathrm{Kg}$ & $\begin{array}{l}\text { @ Rp. } \\
28.000\end{array}$ & Rp. 56.000 \\
\hline Total & & & Rp. 1.050 .000 \\
\hline
\end{tabular}




\section{ASPEK KEUANGAN}

Kami mempunyai Asset sebesar Rp. 10.000.000 untuk memenuhi biaya bahan baku dan biaya promosi sebesar Rp. 800.000 dan sisanya akan kami masukkan ke dalam biaya peralatan.

Investasi Harta Tetap

Peralatan Produksi :

Steling

Meja @Rp.200.000x4

Kursi @Rp. 52.000x16

Kompor Gas 2 tungku

Tabung Gas 3kg dan isi @ 120.000

Wajan/Kuali@Rp.160.000x2

Sodet @Rp.25.000 x 2

Sterofoam@Rp.36.000/lusin x

Ember Kecil @ Rp.6.000 x 2

Tisu@Rp.2.000/bungkus x 182

Tusuk Gigi @ Rp.4.000/bungkusx4 : Rp.

Serbet

$$
\text { :Rp. }
$$

Piring saji @Rp.240.000/lusin x 2 : Rp.

Pisau Steak @ Rp.13.000/lusin x 2 : Rp.

Garpu@ Rp. 10.000/lusinx2

Pisau@Rp.3.000

:Rp.

:Rp.

Kotak pendingin @Rp.150.000x2 : Rp.

Cetakan Telur@ Rp.5.000x12 : Rp.

Total

Modal Kerja

Total Biaya Pokok Produksi

\section{Total Biaya Pokok Produksi}

Rp.
Rp.

5.498 .000
1.500 .000 800.000

832.000

450.000

120.000

320.000

50.000

108.000

12.000

364.000

16.000

$25.000 /$

${ }^{1 / 2}$ Lusin

480.000

26.000

20.000

15.000

300.000

60.000

6.548.000 


\section{a. Penjualan burger dan hotdog}

1. Penjualan Burger Buto adalah $=13 \times R$ p. $60.000=$ Rp. $780.000 /$ hari $=$ Rp. $715.000 \times 30=23.400 .000 /$ bulan

2. Penjualan Hotdog Buto adalah $=12 \times R p .55 .000=$ Rp. $660.000 /$ hari $=$ Rp. $600.000 \times 30=R p .19 .800 .000 /$ bulan

Maka penjumlahan dari penjualan burger dan hotdog adalah

1.Dalam 1 Hari

2.Dalam 1 Bulan
$=\mathrm{Rp} \cdot 1.440 .000$

$=$ Rp. 43.200 .000

b. Keuntungan yang diperoleh dari hasil penjulan adalah

1. Rp. 1.440 .000 - Rp. $1.050 .000=$ Rp.390.000/ hari

2. Rp. $43.200 .000-$ RP. $31.500 .000=$ Rp.11.700.000 / bulan

\section{c. Pengembalian modal}

Dengan Total Biaya Pokok Produksi Rp.6.548.000,00 dapat ditanggulangi dengan keuntungan yang diperoleh dari hasil penjulan dalam satu bulan Rp. 11.700.000.

\section{PENUTUP}

Berdasarkan kajian yang menyeluruh terhadap semua aspek dapat diketahui bahwa terjadi peningkatan dalam 
permintaan akan produk kami ini, namun dalam tahun awal ini kami berusaha mempertahankan kontinuitas terlebih dahulu di angka 750 porsi perbulannya.

Demikian proposal ini kami susun untuk dipergunakan sebagaimana mestinya. Dokumen dalam proposal disusun bagi para wirausahawan yang ingin belajar berwirausaha dengan mudah. Kami harap kerjasama dalam bidang penjualan berjalan dengan lancar tanpa hambatan. Sehingga dapat membangun keberanian di dalam diri para wirausahawan. Diharapkan permasalahan dalam memfasilitas kebutuhan dan perlengkapan yang dibutuhkan.

Atas perhatian dan kerjasamanya, kami ucapkan terima kasih.

Hormat kami

Penulis

Rangkuman

1. Proposal berasal dari kata to propose yang artinya mengajukan. Istilah proposal berarti ajuan penawaran beberapa gagasan, ide dan pemikiran kepada pihak lain untuk mendapat dukungan, persetujuan, izin dan sebagainya. Sebuah Proposal Bisnis haruslah mengandug tiga syarat utama, yaitu mempunyai tujuan, terncana dan sistematis. 
2. Tujuan Proposal Bisnis

Adapun tujuan proposal bisnis yakni:

a. Memberikan gagasan dalam menjalankan usaha Anda, agar tetap berada dalam alur yang diinginkan.

b. Dapat digunakan untuk meyakinkan pihak-pihak yang akan memberikan dukungan pendanaan

Pertanyaaan Untuk Diskusi

1. Jelaskan pengertian proposal bisnis

2. Jelaskan tujuan proposal bisnis

3. Jelaskan Keuntungan proposal bisnis

Tugas

Buatlah proposal bisnis mulai yang mencakup latar belakang, aspek organisasi dan manajemen, aspek produksi, aspek manajemen, aspek pemasaran, aspek keuangan dan penutuhp. 


\section{DAFTAR PUSTAKA}

Aditi, B., \& Hermansyur, H. M. (2017). Pengaruh kualitas produk, citra merek, harga, dan promosi, terhadap keputusan pembelian mobil merek honda di kota medan. Jkbm (Jurnal Konsep Bisnis Dan Manajemen), 3(2), 154165.

Aditi, B. (2017, December). The Effect Of Atributes Product's Analysis, Halal Certification, And Product Innovation To The Interest Of Consumer Buying-Back Through The Advantage Competitive Of Micro Small And Medium Business (MSMB) In Medan. In Journal of Physics: Conference Series (Vol. 930, No. 1, p. 012020). IOP Publishing.

Aditi, B.dan Pentana,S, 2018. Kewirausahaan dan pengembangan UMKM.Medan: Perdana Medika.

Agus Nggermanto (2010). Quantum Quotient. Bandung: Nusantara.

Alifuddin,M. \& Rajak,M. (2015). Strategi membangun kerajaan Bisnis.teori dan aplikasi.Jakarta: Magnascript Publishing

Armstrong dan Kotler. 1996 . Dasar - Dasar Pemasaran . Jakarta : Intermedia.

Armstrong dan Philip Kotler. 2003. Manajemen Pemasaran, Edisi Kesembilan. Jakarta: PT.Indeks Gramedia.

Buchari, A 2004. Manajemen Pemasaran dan Pemasaran Jasa. Bandung: Alfabeta.

Budihardjo, Andreas.(2017).Knowledge Management Efektif Berinovasi Meraih Sukses.Jakarta:Prasetiya Mulya Publishing

Craven, W. David. 1998. Pemasaran Strategis. Jakarta: Erlangga.

Canargie, R., \& Butlin, M.1993.Managing the Innovative Enterprise:Australian Companies competing against the World's Best Business. Business Council of Australia, Melbourne 
Clark, K.B. 1985. The Interaction of Design Hierarchies and Market. Concepts in Technological Evolution. Research Policy, 14.pp.235-251

Dewanti, R. (2008). Kewirausahan.Jakarta: Mitra Wacana Media

Dodgson, M., and Rothwell, R., (1994).The Handbook of Industrial Innovation. Edward Elgar, Cheltenham, UK.

Drucker. F Peter, 1985. Innovation and Entrepreneurship:

Practice and Principles. New York : Harper \& Row

De Meyer, A., \& Garg.S.2005. Inspire to Innovate: Management \& Innovation in Asia. New York: Palgrave Macmillan.

Robert T Kiyosaki dan Sharon L Lechter, Rich Dad Poor Dad for Teens,Rahasia Tentang Uang - Yang Tidak Kau Pelajari Di Sekolah, terj. Ratu Fortunata Rahmi Puspahadi, Jakarta: Gramedia Pustaka Utama, 2004.

Fandy Tjiptono, 2004, Strategi Pemasaran, edisi kedua, Andi, Yogyakarta

Fandy Tjiptono. 2006. Manajemen Jasa . Edisi Pertama. Yogyakarta : Andi

Fahmi, I (2013).Kewirausahaan Teori, Kasus dan Solusi. Jakarta: Alfabeta

Ferdinand, A. 2006. Metode Penelitian Manajemen. Balai Pustaka UNDIP.

Fischer,S.2003.Globalization and Its Challenges.America Economic Review. May,pp.1-29

Geoffrey, G. Meredith, et. Al. (1996). Kewirausahaan Teori Dan Praktek. Jakarta : PT. Pustaka Binaman Presindo.

Greasley, A. 2006. Operations Management In Business. United Kingdom: Stanley Thomes Ltd

Greogy Moorhead dan Ricky W. Griffin.2013 ." Perilaku Organisasi Manajemen Sumber Daya Manusia dan Organisasi " edisi 9 . Jakarta.Salemba empat

Hair, J.F, Bush, P.R.Ortinau. J.D. 2006. Marketing Research : Within a Changing Information Environment 3th edition, McGraw-Hill/Irwin. New York.

Henny Lubis,Zurika, Yusrita, Dewi Andriani, Siregar, Elizabeth Haloho, Bunga Aditi (2016). Pengantar

Kewirausahaan.Medan: Perdana Publishing 
Henderson R.M. \& K.B. Clark. (1990).Architectural Innovation: The Reconfiguration of Existing Product Technologies and the Failure of Established Firms. Administrative Science Quarterly.

Hill, C.W.L., Jones, G.R. 2010. Strategic Management: An Integrated Approach:Theory. Mason: Cengage Learning.

Hisrich,

R.d.\&

Peters.M.P.1992.Entrepreneurship.Starting.Developing.

and Managing A New Entreprise. New York. Richard D.Irwin.Inc.

Hisrich, R.D, Peters, M.P ., \& Shepherd, D.A 2008. Enterpreneurship: Mc Graw hill International edition

Indra Syafii, Bunga Aditi (017). Inovasi dan Kepuasan.Medan:

STIE Harapan

Indriyo Gitosudarmo. 1992. Pengantar Bisnis. Yogyakarta: BPFE.

Jorna, R.J.2006.Knowledge as a Basis for Inovation:Management and Cration.In Jorna, R,J.(ed).Sustainable Innovation:The Organizational Human and Knowledge Dimension.Sheffield,UK: Greenleaf Publishing.

Kasali, Rhenald. 2005. Change. Jakarta: Gramedia Pustaka Utama

Kuriloff, Arthur H., John M. Memphil, Jr. Douglas Cloud.

1993. Starting and Managing the Small Business 3 rd ed.New York: McGraw Hill.

Kim, Chan. W. dan Mauborgne, Renee. (2007). Blue Oc ean Strategy. PT.

Serambi IlmuSemesta, Jakarta.

Kadarningsih, Ana, 2013. Keunggulan Bersaing ; FaktorFaktor yang Mempengaruhi Dan Dampaknya pada Kinerja Selling-In ( Studi pada Outlet Binaan PT. Indosat Semarang). Jurnal Media Ekonomi \& Teknologi Informasi Vol.21 No. 1 Maret, 01 -18,.

Kotler, P and Armstrong. (2001). Prinsip-prinsip Pemasaran. Edisi Kedelapan Jilid I. Jakarta: Erlangga.

Kotler, Philip dan Kevin Lane Keller (2008). Manajemen Pemasaran . Jilid 1. Jakarta: Erlangga. 
Kotler, P. (2006). Manajemen Pemasaran. Edisi 11. Jakarta: Indeks

Kotler dan Keller. (2009). Manajemen Pemasaran . Jilid I. Edisi ke 13 Jakarta: Erlangga

Lamb, C.W, Hair, J.F and McDaniel, C. (2001). Pemasaran. Buku Pertama. Penerjemah: David Octeravia. Jakarta: Salemba Empat.

Li, S., Nathan, B.R., Nathan, T.S.R., Rao, S.B. 2006. The Impact Of Supply Chain Management Practices On Competitive. The International Journal of Management Science Vol. 34, 107-124.

Masykur Wiratmo. 1996. Pengantar Kewiraswastaan-Kerangka Dasar memasuki Dunia Bisnis. Yogyakarta: BPFE.

Mcgrath , R. G. and I. MacMillan. (2000). The Entrepreneurial Mindset . Boston USA :Harvard Business school Press.

M. Hariwijaya, 2005. Proposal Bisnis menyusun proposal yang brillian untuk memulai bisnis anda.Jogyakarta: Zenith Publisher.

Muluk, Khairul M. R. 2008 . Knowledge Management: Kunci Sukses Inovasi Pemerintah Daerah . Malang: Bayumedia Publishing

Nasution, Hermen, Sembiring Baren Ratur, Suyon Bakri, Suadi Rini (1997). Pengembangan Kewirausahan: Medan: Usu Press

Nasution, H.N. 2005. Inovasi Organisasi: Konsep dan Pengukuran. Usahawan. No. 09 th XXXIV September 2005.

Nenny, 2008. "Industri Kreatif", Jurnal ekonomi Desember 2008 Volume XIII No. 3

Nonaka.I.(1994).A Dynamic Theory of Organizational Knowledge Creation. Organizaton Science, Vol.5 No. 1, pp 14-37

Nystrom,H.(1990). Technological and market Innovation Strategies for Product and Company Development.London: John Willey \& Sons.

Pasaribu,Manarep.(2016). Knowledge, Innovation, \& Entrepreneurship.Jakarta: Kepustakaan Popular Gramedia Porter, Micahel E. (1980). On Competition.Boston: Harvard Business School publishing 
Porter (1980) Porter, M. E. 1980. Competitive Strategy:

Techniques for Analyzing Indstries and Competitors, The

Free Press.

Rhenald Khasali, et al. 2010. Modul Kewirausahaan Strata 1. Yogyakarta: Mizan Media Utama.

Rogers, M.Everett, 2003. Diffusion of Innovation .5th

Edition.Free Press, New York

Rogers, E.M. \& Shoemaker, F.F. (1971). Communication of Innovation: Crosscultural Approach, New York: Free Press

Saladin, D. Oesman, Y. (2002). Intisari Pemasaran dan Unsur Pemasaran. Bandung : Lindakarya.

Scarborough,N.M.,Wilson,D.L.,\& Zimmerer,T.W.2009.'Effec tive Small Business Management:An Entrepreneurial Approach.'Prentice Hall Higher Education.

Schumpeter, J.A (1934). The theory of economic Development. Cambridge: Harvard University Press

Slamet, Franky, dkk (2014). Dasar-Dasar Kewirausahaan: Teori dan Praktik.Jakarta: Indeks

Soetrisno. 1009. Pengantar Bisnis. Yogyakarta: Bagian Penerbitan Fakultas Ekonomi Universitas Islam Indonesia.

Sugiyono. 2008. Metode Penelitian Bisnis. Cetakan Keenam. Bandung: Alfabeta.

Sugiyono. (2010). Statistika untuk Penelitian. Bandung: Alfabeta

Suryana (2006). Kewirauahaan Pedomana Praktis: Kiat dan

Poses Menuju Sukes.Jakarta: Salemba Empat

Syahrial Yusuf (2010( .Entrepreneurship Teori dan Praktik

kewirausahaan.. Jakarta: Lentera Ilmu Cendikia

Tjiptono, Fandy. 2010. Strategi Pemasaran. Yogyakarta: Penerbit Andi.

Van de Ven, Andrew H., dan Diane L. Ferry.(1980). Measuring and Assessing Organizations.Wiley, New York.

Weiss,D.s., \& $\quad$ Lengrand,C.P.(2011)..Innovative Intellegence.Canada: John Willey \& Sons, Ltd.

Wijayanti, Titik.(2017).Marketing Plan Dalam Bisnis.Jakarta: PT Elex Media Komputindo. 
Zimmer, Thomas W. Norman Scarborough. 2008 .

Kewirausahaan dan Manajemen Usaha Kecil. Jakarta:

Salemba Empat.

Zimmer, Thomas dan Norman M. Scarborough. 2002.

Pengantar Kewirausahaan dan Manajemen Bisnis Kecil. PT. Prenhallindo, Jakarta 


\section{PROFIL PENULIS}

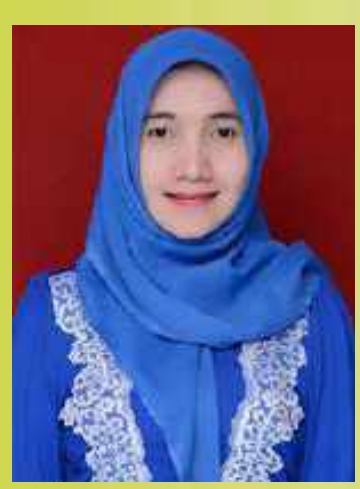

Bunga Aditi, S.E.,M.Si, lahir di Medan, 15 Oktober 1981. Adalah Dosen Tetap Universitas Harapan Medan Fakultas Ekonomi Bisnis. Menyelesaikan Pendidikan Sarjana Program Studi Manajemen di STIE Harapan (2011). Pendidikan Magister berhasil diselesaikan dari Universitas Sumatera Utara (2013).

Beliau adalah salah satu anggota Asosiasi Dosen Indonesia (ADI) dan Anggota Dosen Pendidik Kewirausahaan Indonesia (PERWIRA). Saat ini aktif mengajar mata kuliah yang berkaitan dengan kewirausahaan pengantar Bisnis. Aktif Mengajar STIE Harapan yang saat ini telah berubah nama menjadi Universitas Harapan Medan sejak Oktober 2014.

\section{ISBN : 978-602-52932-8-3}

